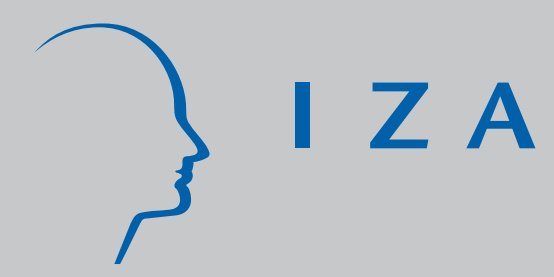

IZADP No. 1654

Unhealthy Assimilation:

Why Do Immigrants Converge to American Health Status Levels?

Heather Antecol

Kelly Bedard

J uly 2005 


\title{
Unhealthy Assimilation: Why Do Immigrants Converge to American Health Status Levels?
}

\author{
Heather Antecol \\ Claremont McKenna College \\ and IZA Bonn \\ Kelly Bedard \\ University of California, Santa Barbara
}

Discussion Paper No. 1654

July 2005

IZA

P.O. Box 7240

53072 Bonn

Germany

Phone: +49-228-3894-0

Fax: +49-228-3894-180

Email: iza@iza.org

Any opinions expressed here are those of the author(s) and not those of the institute. Research disseminated by IZA may include views on policy, but the institute itself takes no institutional policy positions.

The Institute for the Study of Labor (IZA) in Bonn is a local and virtual international research center and a place of communication between science, politics and business. IZA is an independent nonprofit company supported by Deutsche Post World Net. The center is associated with the University of Bonn and offers a stimulating research environment through its research networks, research support, and visitors and doctoral programs. IZA engages in (i) original and internationally competitive research in all fields of labor economics, (ii) development of policy concepts, and (iii) dissemination of research results and concepts to the interested public.

IZA Discussion Papers often represent preliminary work and are circulated to encourage discussion. Citation of such a paper should account for its provisional character. A revised version may be available directly from the author. 
IZA Discussion Paper No. 1654

July 2005

\section{ABSTRACT}

\section{Unhealthy Assimilation: Why Do Immigrants Converge to American Health Status Levels?}

It is well documented that immigrants are in better health upon arrival in the United States than their American counterparts, but that this health advantage erodes over time. We study the potential determinants of this "healthy immigrant effect", with a particular focus on the tendency of immigrants to converge to unhealthy American BMI levels. Using data from the National Health Interview Survey, we find that the average female and male immigrants enter the U.S. with BMIs that are approximately two and five percentage points lower than nativeborn women and men, respectively. And, consistent with the declining health status of immigrants the longer they remain in the United States, we also find that female immigrants almost completely converge to American BMIs within ten years of arrival and men close a third of the gap within fifteen years.

JEL Classification: I1, J1

Keywords: immigrant, assimilation, health

Corresponding author:

Heather Antecol

Department of Economics

Claremont McKenna College

Claremont, CA 91711

USA

Email: heather.antecol@claremontmckenna.edu 


\section{Introduction}

According to the U.S. Census, the foreign born population reached an all-time high of 32 million persons in 2000, an increase of 12 million people since 1990. This means that immigrants constituted 10 percent of the U.S. population in 2000 compared to only 8 percent in 1990 . The large and increasing presence of immigrants highlights the importance of monitoring immigrant health, since immigrant health (and the health of their descendants) has a larger impact on the overall health outcomes of the American population the bigger the immigrant population becomes. Further, larger immigrant populations may increase pressure on the U.S. health care system, as there is empirical evidence showing that immigrants place a burden on Medicaid (Borjas and Hilton 1996). ${ }^{1}$

Researchers from a wide array of disciplines have studied health differences between immigrants and native-born Americans. A key stylized fact that is generally supported in the literature is that upon arrival in the United States immigrants are healthier than their native counterparts, but that over time this health advantage dissipates (House et. al. 1990 and Stephen et. al. 1994). A similar pattern has also been documented in other major immigrant receiving countries. For Canadian evidence, see Chen et. al. (1996), Perez (2002), Deri (2003), and McDonald (2003) and for Australian evidence see Donovan et. al. (1992). This phenomenon is often called the “Healthy Immigrant Effect”, henceforth referred to as the HIE.

The existence of the HIE has spawned a growing literature that seeks to explain this effect. The usual hypothesized contributing/mitigating factors include: selective immigration, medical care access, income assimilation, and acculturation. We discuss each of these in turn.

Selection: There are several counter-veiling selection effects at work with regards to the HIE.

\footnotetext{
${ }^{1}$ Borjas and Trejo (1991) similarly find that recent immigrant cohorts are more welfare dependent than earlier cohorts and that immigrant households are more likely to receive welfare the longer they reside in the United States. They further show that the changing national origin mix explains the increase take-up in welfare among recent immigrant cohorts.
} 
First, immigrants are positively selected and are hence in better health either by choice or due to the U.S. immigration screening process (Marmot et. al. 1984; MacDonald 2004; and Jasso et. al. 2004). Second, unhealthy immigrants may be more likely to return to their home country (Palloni and Arias 2003). Or, third, more economically successful immigrants may be more likely to remain in the United States, and to the extent that higher income individuals are healthier this biases the immigrant sample towards being healthier. Finally, less healthy immigrants may be more likely to die prematurely, making it important to consider the sample age range carefully. While positive selection into the Unites States upwardly biases the estimated immigrant health premium upon entry (i.e., the cohort effects), the remaining selection mechanisms downwardly bias the estimates of immigrant health convergence towards lower U.S. health levels. As such, all of the assimilation estimates reported in this paper should be interpreted as lower bounds.

Health care access: Improved access to health care for immigrants with time in residence might reduce reported health status by increasing the diagnosis of pre-existing conditions (McDonald And Kennedy 2004 and Jasso et. al. 2004). On the other hand, it has also been suggested that increased access to health care may improve reported health status by reducing immigrant/native gaps in preventative health care screening, diagnosis and treatment of health care problems (Leclere et. al., 1994, Laroche 2000, and McDonald and Kennedy 2004). As such, it is difficult to predict the direction of the change in immigrant self-reported health status over time that results from changes in health care access.

However, we do know that immigrant health status is initially higher than that of natives and then falls towards American levels. Two things are therefore necessary for health care access to play a role in immigrant assimilation towards American health levels. First, immigrant health care access must change with the length of time that cohorts remain in the United States. Secondly, health care 
access must either fall the longer immigrants remain in the country, which seems incredibly unlikely, or must lead to the detection of previously unknown health problems which cause immigrants to report worse health.

Income assimilation: It is well known that most immigrant groups enter the United States with lower incomes and employment rates and subsequently converge towards native levels the longer they remain in the country. ${ }^{2}$ Given immigrant income assimilation and the general finding that health is positively related to income (Sorlie et. al., 1995), immigrants should become healthier the longer they remain in the country (Jasso et. al. 2004). This is exactly the opposite of the HIE: Immigrants arrive healthier and then become less healthy, not the reverse.

Acculturation: Exposure to the U.S. environment causes immigrants to adopt native-born behaviors (such as, diet and exercise) that have important health implications (Marmot and Syme 1976; Kasl and Berkman 1983; Stephen et. al. 1994; and McDonald 2004). ${ }^{3}$ One of the most important, but largely overlooked types of acculturation, is the role that BMI (body mass index) assimilation plays in explaining the HIE. While the growing obesity rate is well documented for the American population (Costa and Steckel 1995; Philipson and Posner 1999; Himes 2000; Philipson 2001; Lakdawalla and Philipson 2002; Chou, Grossman, and Saffer 2002; and Cutler, Glaeser and Shapiro 2003), it has been essentially overlooked for the foreign born population. ${ }^{4}$

The rising obesity rate is of great concern to policymakers due to its associated health risks, and hence costs. To put it in context, only tobacco use leads to higher rates of premature death than obesity (Chou, Grossman, and Saffer 2002). In particular, obesity increases the risk of heart disease,

\footnotetext{
2 Examples include: Chiswick 1986; LaLonde and Topel 1992; Duleep and Regets 1994, 1999, 2002; Funkhouser and Trejo 1995; Borjas 1985, 1995; Schoeni 1997, 1998; Hu 2000; and Antecol, Kuhn and Trejo 2003.

${ }^{3}$ Alternatively, the act of migration may lead to worse health either due to the stress associated with the immigration process (Kasl and Berkman 1983) or exposure to discrimination in the host country (Vega and Amaro 1994).
} 
stroke, some types of cancer and diabetes, and hence the financial burden due to greater health care consumption and/or productivity loss (Wolf and Colditz 1998 and Sturm 2002). ${ }^{5}$ And, of course, these elevated costs are not borne entirely by the obese themselves since half of all health care is paid for by federal, state or local governments (Chou, Grossman, and Saffer 2002).

The objective of this paper is two-fold. We first document the HIE using the National Health Interview Surveys (NHIS). However, unlike much of the previous literature we control for differences in cohort quality. ${ }^{6}$ Secondly, we examine a complementary explanation of the HIE: the BMI (kgs/meters $\left.{ }^{2}\right)$ assimilation aspect of acculturation, which has received limited attention in the literature. The absence of research in this area is in part due to data limitations as few data sources provide information on weight and height as well as immigrant status. Fortunately, the 1989-96 NHIS includes detailed information on immigration (e.g., year of arrival) and demographics (age, education, and so on) as well as weight and height.

We find support for the HIE in the NHIS using three measures of health (self-reported health status, health conditions, and activity limitations). Immigrants enter healthier but then converge towards native levels. Consistent with this finding, we find that immigrant women enter the country with BMIs that are approximately 2 percentage points lower than native-born women, but almost entirely converge to American BMIs within the first decade of residence in the United States. In contrast, immigrant men enter with BMIs that are approximately 5 percentage points lower than native-born men and close only one-third of the gap even after 15 years of U.S. residence. While convergence in average BMI is interesting, it masks an even greater difference in the percentage of

\footnotetext{
${ }^{4}$ One exception is McDonald (2004), who examines the role obesity plays in explaining the HIE in Canada. And, there is a growing literature documenting obesity rates among foreign-born adolescents (see for example, Popkin and Udry 1998 and Gordon-Larsen et. al. 2003).

${ }^{5}$ A related literature also finds that there is a wage penalty associated with obesity (Register and Williams 1990; Hamermesh and Biddle 1994; Averett and Korenman 1996; Pagan and Davila 1997; and Cawley 2000).
} 
natives and immigrants who are overweight $(\mathrm{BMI} \geq 25)$ and obese (BMI $\geq 30)$. For example, immigrant women (men) are about 10 (16) percentage points less likely to be overweight than natives at entry and they close 90 (50) percent of the gap within 10 (15+) years of U.S. residence.

The remainder of the paper is as follows. Sections 2 and 3 describe the data and the estimation strategy, respectively. Section 4 documents the HIE. Section 5 explores the BMI entry and assimilation patterns of immigrants. Section 6 concludes

\section{Data}

All data are drawn from the National Health Interview Surveys (NHIS) from 1989-96. The NHIS is an annual cross-section survey intended to obtain information about the distribution of illness and the health services that people receive. Approximately 120,000 individuals in 45,000 households are surveyed each year. Information regarding basic socioeconomic characteristics as well as summary health measures such as self-reported health status and activity limitations are collected for all individuals, and measures of weight and height are collected for individuals aged eighteen and older.

Our analysis is restricted to 1989-96 because years of U.S. residence are only reported in these years. To ensure a representative sample, we also restrict the sample to men and women aged 20-64; since overweight individuals may be less healthy and hence have higher pre-mature mortality rates.

All of the analysis is carried out on four groups: all racial/ethnic origin groups, Hispanics, non-Hispanic whites, and non-Hispanic blacks - henceforth referred to as all origins, Hispanics, whites, and blacks - and immigrants by year since arrival to the United States $(0-4,5-9,10-14$, and 15+). The sample includes 429,482 and 61,234 natives and immigrants, respectively, from all origin groups, of which 20,510 (26, 496), 342,899 (17,793), and 60,179 (4,439) are Hispanic, white, and

\footnotetext{
${ }^{6}$ This technique is commonly used in the labor economics literature to examine wage and employment assimilation (see
} 
black natives (immigrants), respectively. ${ }^{7}$ Not surprisingly, given the open-ended nature of the $15+$ years since arrival category, it is by far the largest group of immigrants with 29,099 immigrants, while 0-4 years since arrival includes 11,047 immigrants, 5-9 years since arrival includes 11,033 immigrants and 10-14 years since arrival includes 10,145 immigrants. However, due to a small amount of non-reporting for some health measures, the exact sample sizes vary slightly across outcomes.

Tables $1 \mathrm{a}$ and $1 \mathrm{~b}$ report summary statistics by racial/ethnic origin (henceforth referred to as race) for the variables used throughout the analysis for women and men, respectively. ${ }^{8}$ For both natives and immigrants we have measures for age, an indicator for currently married, years of education, an indicator for currently employed and indicators for urban residence and region of residence. ${ }^{9}$ For all immigrants Table 1 also reports immigrant arrival cohorts (1980 or before, 198185, 1986-90, and 1991-96) ${ }^{10}$ and the years since arrival (0-4, 5-9, 10-14, and 15+).

Throughout the analysis, we use three self-reported health indicators: poor health, the presence of at least one health condition, and the existence of at least one activity limitation. Poor health is defined as one if the individual reports their health status as fair or poor and zero if they report their health status as excellent, very good, or good. An individual is defined as having at least one health condition if they report one or more health conditions. Finally, the activity limitation indicator is set equal to one if the respondent is unable to perform their major activity (i.e., work), is

Borjas 1985 for the classic study).

${ }^{7}$ The sample size for the all origins category is larger than the sum of the Hispanic, white, and black samples because it also includes all "other" racial/ethnic origins (e.g., Asians, Indians, etc). However, this category is not analyzed separately due to small sample sizes.

${ }^{8}$ All variables are defined in Appendix Table 1.

${ }^{9}$ To conserve space, the regional indicators are not reported in Table 1, but are included in all models.

${ }^{10}$ The NHIS reports years since U.S. arrival rather than immigrant arrival cohorts. As such, we assign individuals to five-year cohorts to maximize the number of immigrants placed in the correct arrival cohort. Immigrants reporting 15+ years of U.S. residence in all NHIS years and those reporting 10-14 years in 1989-92 are designated as arriving in 1980 or earlier. Immigrants reporting 10-14 years in 1993-96 and 5-9 years in 1989-92 are designated as arriving in 1981-85. 
limited in the kind or amount of their major activity, or is limited in any activity. For the sample as a whole, approximately 11 (9) percent of native and 12 (9) percent of immigrant women (men) report poor health, 46 (40) percent of native and 34 (26) percent of immigrant women (men) report at least one health condition, and 15 (14) percent of native and 11 (9) percent of immigrant women (men) report an activity limitation. While the magnitudes vary by race, the overall patterns generally hold. $^{11}$

While reported height and weight can be used to construct the BMI ( $\mathrm{kgs} /$ meters $\left.^{2}\right)$, which adjusts weight for height differences, self-reported height and weight are subject to reporting errors that may bias coefficient estimates. Unfortunately, the NHIS does not include measured height and weight. As such, we are forced to use self-reported measures. For our purposes we are particularly concerned that different racial and/or immigrant groups may differentially misreport. For example, in a similarly aged sample in the Third National Health and Nutrition Examination Survey (NHANES III) conducted in 1988-94, the average immigrant woman under-reports her weight by 1.3 percent while the average native woman under-reports her weight by 2.4 percent. On the other hand, the average native and immigrant man both under report their actual weight by 0.8 percent.

Following Cawley (2000) we address this misreporting problem using the strategy described in Lee and Sepanski (1995) and Bound, Brown and Mathiowetz (1999). More specifically, we correct self-reported weight and height using data from NHANES III, which is a nationally representative sample containing information on immigrant status as well as self-reported weight and height and professionally measured weight and height. As such, we regress measured (true) weight (height) on reported weight (height) and reported weight (height) squared separately for men

Immigrants reporting 5-9 years in 1993-96 and 0-4 years in 1989-92 are designated as arriving in 1986-90. Finally, immigrants reporting 0-4 years in 1993-96 are designated as arriving in 1991-96.

11 The main exception is reports of poor health for black women and men, where natives are 10 percentage points more likely to report poor health than their immigrant counterparts. 
and women by race/immigrant group (white, black, Hispanic and other immigrants and natives - 16 groups in total). ${ }^{12}$ The estimates used for the adjustment of weight and height is reported in Appendix Tables 2a and 2b, respectively. We then use the coefficient estimates to predict measured weight and height in the NHIS data. ${ }^{13}$ All summary BMI statistics and estimates reported in this paper are based on predicted weight and height. That being said, all results are similar if reported weight and height are used instead (this is discussed in detail in Section 5).

Rows 5-7 in Tables 1a and $1 \mathrm{~b}$ report the average BMI, the percentage defined as overweight $(\mathrm{BMI} \geq 25)$ and the percentage defined as obese (BMI $\geq 30)$ for women and men, respectively. ${ }^{14}$ While average BMI is virtually identical for natives and immigrants, irrespective of gender and race, ${ }^{15}$ the same is not always true for the percent overweight and the percent obese. Specifically, immigrant and native women are equally likely to be overweight (44 percent), but are less likely to be obese (15 percent) than their native counterparts (19 percent). In contrast, 59 (18) percent of native men are overweight (obese) compared to only 49 (10) percent of immigrant men. These averages, however, hide interesting differences by race, particularly for women. For example, Hispanic (black) immigrant women are 6 (4) percentage points more (less) likely to be overweight than their native-born counterparts, while white native and immigrant women are indistinguishable.

\section{Empirical Framework}

As previously stated, our goal is to (1) document the HIE and (2) to examine the BMI assimilation pattern of immigrants to the United States. For all outcome measures, we examine immigrant

\footnotetext{
${ }^{12}$ All models are appropriately weighted.

${ }^{13}$ See Appendix A in Cawley (2000) for a more detailed discussion of these issues. This, of course, assumes that the relationship between reported and measured height are the same in the NHANES III and NHIS.

${ }^{14}$ We exclude 52 respondents who reported extreme heights (under 48 inches or over 84 inches) from the weight analysis. However, all results are similar if these individuals are included.
} 
assimilation using the regression framework developed by Borjas $(1985,1995)$. To begin we focus on the assimilation of immigrants to natives for all origin groups combined using eight NHIS crosssections from 1989-1996. The availability of repeated cross-sections is crucially important because it allows us to track health outcomes for immigrant arrival cohorts over time. ${ }^{16}$

In particular, we estimate equations of the following form:

$Y_{i}=X_{i} \beta+A_{i} \delta+C_{i} \lambda+T_{i} \pi+\varepsilon_{i}$

where $i$ denotes individuals, $Y$ represents the outcome measure of interest, $X$ is a vector of control variables, $A$ is vector of dummy variables indicating how long an immigrant has lived in the United States (set equal to zero for natives), $C$ is a vector of dummy variables identifying immigrant arrival cohorts, $T$ is a vector of dummy variables indicating the survey year, and $\varepsilon$ is a random error term. This specification gives each immigrant arrival cohort its own intercept, and differences in these intercepts represent permanent outcome differentials between cohorts. The coefficients for the duration of U.S. residence dummies (A) measure the effects of immigrant assimilation with respect to the outcome measure in question. ${ }^{17}$

In order to identify the cohort and assimilation effects, we restrict the period effect, $\pi$, to be the same for immigrants and natives. In essence, this means that the period effects are estimated from natives, and this information is used to identify cohort and assimilation effects for immigrants. Although not necessary for identification, equation (1) also restricts the effects of the variables in the control vector $(X)$ to be the same for immigrants and natives and across survey years. We also estimated less constrained models that did not impose these latter restrictions and obtained very

\footnotetext{
${ }^{15}$ The one exception is that black native women have higher average BMIs (28) compared to black immigrant women (26.7).

${ }^{16}$ It should be noted, however, that not every arrival cohort is observed in every years since migration category.

${ }^{17}$ Given these variables, the specification defined in equation (1) therefore assumes that the assimilation pattern is constant across arrival cohorts.
} 
similar results.

We then estimate equation (1) separately by race. Specifically, we focus on the assimilation of Hispanic immigrants to Hispanic natives, white immigrants to white natives, and black immigrants to black natives. By estimating the model within race, as opposed to using white natives as the base group (which is the usual approach in the labor market assimilation literature), we avoid confounding possible race differences with assimilation.

\section{The Healthy Immigrant Effect}

Do immigrants arrive in the U.S. healthier than their native counterparts? And, do immigrants converge to American health levels? In order to answer these questions we estimate equation (1) for three indicator variables for health: poor health (=1 if self-reported health is either fair or poor), health conditions ( $=1$ if one or more health conditions are reported), and activity limitations (=1 if activity or work is limited).

Tables 2a and 2b present the immigrant cohort and assimilation effects for our three health measures by race for women and men, respectively. All health equations are estimated as probit models. In order to more easily describe the quantitative importance of the explanatory variables in the probit specifications, Table 2 (and all remaining tables) report the marginal effects for continuous variables and average treatment effects for the discrete variables, in both cases evaluated at means, as well as standard errors calculated using the “delta” method. In addition to the variables listed in Table 2, all regressions include controls for age, age squared, years of education, and indicator variables for married, employed, residence in an urban area, region of residence, and survey year. $^{18}$

\footnotetext{
${ }^{18}$ The coefficient estimates and marginal effects for these variables are available upon request.
} 
Overall the period effects indicate that Americans are getting less healthy over time irrespective of gender and the health measure analyzed. Between 1989 and 1996, holding all else constant, the average female probability of being in poor health increased by 1.3 percentage points and the average male probability of being in poor health increased by 0.8 percentage points. While the same pattern holds for whites, the period effects are less pronounced for Hispanics and blacks. In order to avoid overly cluttered tables, and because the results mirror those in the established literature, we do not report these marginal effects in Tables 2a and 2b.

The immigrant arrival cohort marginal effects reported in Tables 2a and 2b represent immigrant-native health differentials evaluated at 0-4 years of U.S. residence. For example, the estimated marginal effect for 1986-90 Hispanic female immigrants in the health conditions specification indicates that, in their first four years after arriving, this cohort was 7 percentage points less likely to be in poor health relative to otherwise similar Hispanic natives.

That the cohort marginal effects are uniformly negative (although sometimes imprecisely estimated) irrespective of race implies that immigrants who have recently arrived in the United States (those with 0-4 years of residency) are less likely to report poor health, health conditions, and activity limitations than natives. Further, the fact that the marginal effects tend to be similar in magnitude for all of the various recent arrival cohorts suggests that, after controlling for years of U.S. residence, health is similar across cohorts.

We now turn to the assimilation effects. In Tables $2 a$ and $2 b$, the marginal effects for the duration of U.S. residence indicate how health changes the longer an immigrant cohort remains in the United States. The overall assimilation patterns are similar for male and female immigrants, thus we focus on the female assimilation patterns here. While the bulk of assimilation for the probability of being in poor health takes place within the first decade after arrival, immigrant assimilation in 
terms of health conditions and activity limitations occurs more slowly. For example, the probability of being in poor health increases by 2.7 percentage points as female immigrants pass from 0-4 to 5-9 years in the United States, but thereafter increases only a modest 2.6 percentage points. In contrast, the percentage of female immigrants with health conditions, relative to their level during the initial four years of U.S. residence, rises by 3.9 percentage points after 5-9 years, by 5.2 percentage points after 10-14 years, and 14.0 percentage points after more than 15 years.

The overall patterns hide some interesting race differences. First, the overall assimilation patterns hold for Hispanic immigrants, irrespective of gender. Second, the point estimates for black immigrants reveal that neither men nor women assimilate to their black native-born counterparts. Third, the point estimates for white immigrants suggest that there is some convergence towards their white native-born counterparts however these estimates are often imprecise. In particular, the point estimates are more precise for health conditions and activity limitations for white female immigrants, while for white male immigrants the point estimates are more precise for poor health and health conditions.

Finally, recall the negative cohort marginal effects discussed earlier. These marginal effects indicate that, all immigrant cohorts were less likely to be in poor health, by all measures, at the time of arrival (defined as having arrived in the U.S. within the 0-4 years category) compared to natives for all races. However, assimilation towards U.S. levels eventually erases all or most of the initial health advantage for all immigrants, for Hispanic immigrants, and depending on the health measure for white immigrants, but not for black immigrants. As an illustration, consider the 1981-85 arrival cohort for Hispanics. During their first four years in the United States this female (male) cohort had an incidence of being limited in activities that was 7.4 (5.8) percentage points below that of Hispanic natives. But after 10-14 years of U.S. residence, assimilation has reduced the female (male) gap by 
5.4 (5.7) percentage points. After 15 years of U.S. residence Hispanic female (male) immigrants are actually 2.7 (1.7) percentage points more likely than Hispanic natives to be classified as limited in activities. To summarize, these results are generally consistent with an immigrant health assimilation process as opposed to permanent health differences across immigrant cohorts.

Overall these results confirm the existence of the HIE found in the previous literature. In particular, we find that recent immigrants (those with 0-4 years of U.S. residency) are healthier than natives irrespective of race and gender, however this health advantage declines (and/or is erased) with time in the United States for all immigrants, for Hispanic immigrants, and (depending on the health measure) for white immigrants, but not for black immigrants.

\section{Immigrant BMI Patterns}

As previously stated, there is a growing literature documenting the ever-increasing American waistline and the rapidly growing incidence of obesity. The rising obesity rate is of great concern to policymakers due to the associated health risks (e.g., heart disease, stroke, some types of cancer, and diabetes) and hence costs. These facts suggest a possible explanation for why immigrants become less healthy the longer they reside in the United States: immigrant BMIs may be approaching the unhealthy BMIs of their American counterparts. ${ }^{19}$ We focus on three BMI measures: the natural

\footnotetext{
19 Ideally we would like to examine other determinants of the HIE, such as, access to health care and poverty. Unfortunately, the only access to health care measure reported in the NHIS is a binary indicator for whether or not the respondent visited a doctor in previous months. This is a very questionable measure of health care access since it confounds access and utilization. As a result, it is impossible for us to empirically investigate this potential HIE channel. Turning to poverty, the NHIS only includes a categorical measure of nominal family income (with a low top code and a high non-reporting rate) and an indicator variable for households falling below the poverty line. Given the high nonreporting for family income and the difficulty associated with converting nominal categories into real values over time, we can only analyze to the probability of being in poverty. We estimate immigrant entry and assimilation effects using the estimation strategy described in Section 3 and equation (1). The results are reported in Appendix Table 4. Consistent with previous studies, we find that overall all immigrant arrival cohorts are more likely to be in poverty than their native counterparts and that there is a small amount of convergence towards lower native poverty rates with years of U.S. residency. While similar cohort effects are generally found by race (the one exception is black women), there are no assimilation effects by race. As such, the poverty and health assimilation processes move in opposite directions, which is
} 
logarithm of $\mathrm{BMI}^{20}$ (we use logs for interpretative ease), an indicator variable for overweight (=1 if $\mathrm{BMI} \geq 25$ ), and an indicator variable for obese ( $=1$ if $\mathrm{BMI} \geq 30$ ).

\subsection{BMI by Nativity}

Do immigrants converge to unhealthy American BMIs? We begin to answer this question by simply graphing the average BMI for all origin, Hispanic, white and black women (Figure 1A) and men (Figure 1B) from 1989-96. To allow for easy visual analysis of immigrant assimilation patterns, each graph includes a line for natives, immigrants arriving 0-4 years ago, and immigrants arriving 15 or more years ago.

Consistent with Lakdawalla and Philipson (2002) and Cutler, Glaeser, and Shapiro (2003), average BMI rose for both men and women between 1989-96 for all race groups, although the average BMI level does differ across race groups. To put this in perspective, in 1989 the average native white woman had a BMI of 24.5. Over the next seven years this rose by 4 percent to 25.4. While the BMIs for the average native black and Hispanic woman in 1989 were 27.3 and 26.2, respectively, the growth rates were about the same as for native white women. The average upward trend for men was slightly slower, with a growth rate of approximately 3 percent for all race groups. The major difference between men and women is that the racial spread is much smaller for men.

While the upward native trends are important for comparison, for our purposes the immigrant patterns are of greater importance. The following two patterns are noteworthy. First, just as for natives, there is an upward trend for immigrants over time, holding years since arrival constant. Secondly, the longer immigrants reside in the U.S. the higher their BMIs become. The BMI for the

incompatible with the HIE.

${ }^{20}$ All results are similar using BMI levels. 
average female immigrant rises by approximately 6 percent between 0-4 years of U.S. residence and $15+$ years of U.S. residence. However, the average for the all origin group masks important race specific assimilation patterns. For example, Hispanic immigrant women who have lived in the U.S. for 0-4 years have lower BMIs than native Hispanics, while Hispanic immigrant women who have lived the U.S. for 15+ years have higher BMIs than native Hispanics. In contrast, both newly arrived black immigrants and those who have resided in the U.S. for 15+ years have lower BMIs than native blacks, although the group with longer U.S. residence has a higher average BMI than the recently arrived group.

There are two important differences between the female and male patterns. First, for most race groups, the average BMI differential between natives and recent male immigrants is substantially larger than for women. Secondly, with the exception of white immigrants, male immigrants BMIs do not converge to the comparable native level even for the 15+ years of U.S. residency group. This pattern contrasts with the overshooting that we see for female immigrants.

Figures 2 and 3 replicate Figure 1 for the percentage of people classified as overweight and obese, respectively. In both cases the patterns are very similar. The one noticeable difference is that there appears to be somewhat less immigrant convergence in obesity relative to the BMI and the overweight designation. The remainder of the paper provides a more formal analysis of this immigrant convergence.

\subsection{Immigrant Assimilation and Cohort Differentials}

Following the standard Borjas $(1985,1995)$ approach, we begin by presenting the immigrant cohort and assimilation effects for equation (1) for our three BMI measures for all immigrants in the first three columns of Tables 3a (women) and 3b (men). We then present the results for Hispanics, 
whites, and blacks separately in columns 4-12. Further, for each of the four race group specifications the native comparison group is the equivalent race group: all origins (i.e., all American born individuals), Hispanics, whites, and blacks.

The period effects indicate that American BMIs are rising. Between 1989 and 1996, holding all else constant, the average female (male) BMI, probability of being overweight, and probability of being obese increased by 3.8 (3.0), 8.4 (8.0), and 6.0 (6.0) percentage points, respectively (see Appendix Tables 3a and 3b). ${ }^{21}$ Moreover, this pattern holds irrespective of race. This is in sharp contrast to the results for our three health measures presented in Tables 2a and 2b where the period effects were largely driven by whites.

We begin by focusing on the all origins group. As with the health outcomes, the uniformly negative cohort marginal effects imply that both male and female immigrants with 0-4 years of U.S. residency from every arrival cohort have lower BMIs, a lower proportion of overweight individuals, and a lower proportion of obese individuals than natives. Furthermore, we find no evidence of differences across cohorts (i.e., the magnitude of the marginal effects are similar across recent arrival cohorts). However, unlike the health outcomes, there are some important differences across race groups with respect to cohort effects. While Hispanic (and black) immigrants closely resemble the all origins patterns irrespective of gender, the pattern for white immigrants is very different. In particular, with the exception of obesity rates, white female immigrants are indistinguishable from their white native counterparts while white male immigrants from every arrival period initially have lower BMIs, probabilities of being overweight, and probabilities of being obese than their native counterparts. In particular, white male immigrants have BMIs that are 3-4 percent lower and

\footnotetext{
${ }^{21}$ The parameter estimates for age, age squared, years of education, and indicator variables for married, employed, residence in an urban area, region of residence, and survey year are presented in Appendix Tables 3a and 3b for women and men, respectively.
} 
overweight and obesity rates that are 11-14 and 7-11 percentage points lower, depending on the arrival cohort than their white native counterparts.

Turning to the overall assimilation effects (columns 1 to 3 ), the bulk of assimilation (regardless of the outcome measure) takes place within the first decade after arrival for female immigrants. The probability of being overweight (obese) increases by 6.6 (4.3) percentage points as female immigrants pass from 0-4 to 5-9 years in the United States, but thereafter increases only by 3.1 (2.9) percentage points. In contrast, male immigrants assimilate more slowly. The percentage of male immigrants designated overweight (obese), relative to their level during the initial four years of U.S. residence, rises by $2.3(0)$ percentage points after 5-9 years, by $3.8(0)$ percentage points after 10-14 years, and 8.5 (5.3) percentage points after more than 15 years (although some of these effects are imprecisely estimated).

The overall assimilation patterns however mask some important differences by race. First, for female immigrants only Hispanic immigrants converge to their native counterparts irrespective of the BMI measure considered. In other words, the results for the all origins specification for female immigrants appear to be largely driven by Hispanic immigrants. Secondly, Hispanic male immigrants also converge to their native counterparts, but only in terms of overweight rates. Moreover, unlike for female immigrants, there is evidence that white male immigrants do assimilate in terms of overweight and obesity rates. After 15+ years in the United States white male immigrants have narrowed the immigrant-native overweight gap by 11 percentage points and more than eliminated the obesity gap. Finally, black immigrants do not assimilate in terms of BMI irrespective of gender. Caution, however, should be used in interpreting these results due to the small number of black immigrants.

Finally, BMI assimilation eventually erases the entire initial BMI advantage for all female 
immigrant arrival cohorts for the all origins and Hispanic samples and a substantial fraction of the initial BMI advantage for immigrant men for the all origins sample, and depending on the BMI measure for the Hispanic and white samples. For example, during their first four years in the U.S. the 1981-1985 Hispanic female (male) cohort had an incidence of being overweight that was 12.0 (17.8) percentage points below that of Hispanic natives. But after 15 years of U.S. residence, assimilation had more than completely narrowed the female gap and reduced the male gap by 7.2 percentage points. These results are consistent with an immigrant adjustment process as opposed to permanent cohort differences.

Overall, the general patterns found in terms of BMI (irrespective of the measure) mirror the patterns found for general health measures. Recent immigrants have lower BMIs and are healthier than natives, but become heavier and less healthy with time in residence. This suggests that BMI, which is largely determined by diet and exercise ${ }^{22}$ is an important contributing factor for explaining the HIE.

Moreover, the overall results hide some important race difference, particularly for Hispanic women. The high and increasing female Hispanic immigrant BMIs are particularly interesting when considered in conjunction with the health and poverty assimilation patterns, which are inconsistent with the Hispanic Paradox: the finding of lower mortality rates among Hispanic immigrants despite their relatively low socioeconomic status (see Palloni and Arias 2003 and the references therein). Consistent with the paradox, Hispanic immigrant women are 2-11 percentage points (depending on

\footnotetext{
${ }^{22}$ Unfortunately, it is difficult to separate the contribution of diet and exercise from each other due to data limitations. There are two NHIS supplements (in 1990 and 1991) that include information on exercise. However, given the essentially cross-sectional nature of this data, it is impossible to separately identify cohort and assimilation effects in this data. That being said, simple comparisons of immigrant (combining cohort and assimilation factors) and native probabilities show that immigrant women are somewhat less likely to exercise regularly than native women, but no male differences are found. Although this evidence is somewhat difficult to interpret due to the inability to separate the cohort and assimilation effects, it does suggest that both diet and exercise play a role for women, while male BMI assimilation is likely largely driven by dietary changes with time in U.S. residence.
} 
their arrival cohort) more likely to be in poverty than their native born counterparts upon arrival and do not converge to native levels with time of residence (see footnote 19 and Appendix Table 4). But inconsistent with the paradox, Hispanic women have lower probabilities of poor health at entry into the United States but assimilate to, or beyond, American levels of poor health within 10-15 years after arrival. However, the declining relative health of Hispanic immigrant women does match closely with their rising BMIs and is consistent with the higher rates of diabetes among Hispanic women (see Jasso et. al. 2004). Unlike female Hispanic immigrants, the lack of male Hispanic immigrant BMI assimilation seems at odds with the relatively high rates of death due to diabetes among Hispanic men (National Vital Statistics Reports 2003).

\subsection{Robustness Checks}

One potential limitation of the preceding analysis is the use of predicted BMI measures based on NHANES (see Section 2 for a detailed discussion). To ensure that the predicted measures are not driving our cohort and assimilation effects, we re-estimate equation (1) using our unadjusted BMI measures (i.e., BMI based on self-reported weight and height from the NHIS). We find very similar results using the unadjusted measures (see Appendix Tables 5a and 5b for women and men, respectively), thus the patterns found are not an artifact of the BMI measured used.

Another concern is that we have immigrants in our sample that arrived in the United States as children. This may lead to cohort (assimilation) effects that are biased downward (upward) because immigrants who came as children will more likely have health outcomes that more closely align with natives. In an attempt to control for this possibility, we re-estimate equation (1) excluding immigrants who arrived before the age of 15 . In order to determine the age of the immigrant at arrival we used their current age and year since migration. For example, if an individual is currently 
24 and they have been in the U.S. for 12 years (the midpoint of the 10-14 years since migration category), their age at arrival is 12, and they are excluded from the analysis. Because years since migration is open-ended at the top, i.e., $15+$ years since migration, we estimate two specifications: specification 1 top-codes the 15+ years since migration group at 29 years and specification 2 deletes the $15+$ years since migration group. The latter is a more conservative measure, as we are able to exactly identify all individuals age at arrival. Appendix Tables $6 \mathrm{a}$ and $6 \mathrm{~b}$ present the cohort effects and assimilation effects of BMI excluding immigrants who arrived before the age 15 for the all origins and Hispanics for women and men, respectively. ${ }^{23}$ The results are very similar to those presented in Tables 3a and 3b where all immigrants are included.

One may also be concerned that our female estimates partly reflect differential fertility rates across immigrant and native groups. Unfortunately, the person file in the NHIS does not report pregnancy status. Given this data limitation, we are unable to exclude pregnant women from the sample. To check the robustness of our results, we can however exclude women of childbearing age. Appendix Table 7 reports the estimated cohort and assimilation effects for women aged 35 and above. While the patterns reported in Appendix Table 7 are very similar to those reported in Table 3a, some of the point estimates are statistically imprecise due to the substantial reduction in sample size associated with excluding all women under the age of 35.

A final concern is that we are not picking up assimilation but merely the trends in BMI in the country of origin. For example, Popkin and Gordon-Larsen (2004) show that overweight trends in Mexico have grown several times faster than in the U.S. over the past few decades. Although we do not have direct evidence on trends in obesity in the immigrant's country of origin, we can proxy these trends using the NHIS. Specifically, we examine the change in BMI for young recent (0-4

\footnotetext{
${ }^{23}$ We focus on the overall and Hispanic samples in this table because the white and black results are noisy even without these further
} 
years of U.S. residency) immigrants (who likely closely reflect the trends in their countries of origin) and compare them to the trends of young natives by gender, age and race. We consider two age groups, 20-29 and 30-39. If the trends are similar, then it does not appear that the home country trends are biasing our results. Appendix Table 8 presents the BMI trends. Overall, immigrants have lower BMIs than their native counterparts in 1989, both immigrants and natives see an increase in BMI from 1989 to 1996, but the rate of the increase is roughly similar for the two groups irrespective of gender or age group considered. In general similar patterns are found by race, although the rate of increase at times is higher for natives depending on the race group considered. Thus it seems unlikely that it is trends, rather than assimilation, that are driving our results.

\section{Conclusion}

It is well documented that immigrants are in better health upon arrival in the United States than their American counterparts, but that this health advantage erodes over time: the HIE. We find support for the HIE in the NHIS using three measure of health (self-reported health status, health conditions, and activity limitations). We further find substantial evidence that the BMI assimilation patterns of immigrants closely mirror self-reported health assimilation. Overall immigrants arrive in the United States with lower BMIs than natives but then converge towards natives. However, this overall pattern is somewhat misleading. For example, while white female immigrants are indistinguishable from their native counterparts upon arrival, Hispanic female immigrants enter the U.S. with lower BMIs than native Hispanics and then converge towards native levels. On the other hand, male immigrants of all racial/ethnic origins generally enter the U.S. lighter than natives, and never fully assimilate.

exclusions. However, all results are similar for these samples and are available upon request. 
Understanding the intricacies of the immigrant weight assimilation path may give us some insight into the causes of elevated American weight levels. The fact that most immigrant groups arrive with lower BMIS than Americans and then converge towards natives suggests that the new cultural or environmental factors that immigrants are exposed to alter their behavior. Unfortunately, their newly acquired eating habits and weight gain increase the probability of health problems and premature death as well as raise health care costs. 


\section{References:}

Antecol, Heather, Peter Kuhn, and Stephen Trejo. 2003. “Assimilation via Prices or Quantities? Labor Market Institutions and Immigrant Earnings Growth in Australia, Canada, and the United States.” IZA Working Paper No. 802.

Averett, Susan and Sanders Korenman. 1996. "The Economic Reality of the Beauty Myth.” Journal of Human Resources 31(2): 304-330.

Borjas, George J. 1985. “Assimilation, Changes in Cohort Quality, and the Earnings of Immigrants.” Journal of Labor Economics 3(4): 463-89.

. 1995. "Assimilation and Changes in Cohort Quality Revisited: What Happened to Immigrant Earnings in the 1980s?” Journal of Labor Economics 13(2): 201-45.

Borjas, George J. and Lynette Hilton. 1996. "Immigration and the Welfare State: Immigrant Participation in Means-Tested Entitlement Programs.” The Quarterly Journal of Economics 111(2): 575-604.

Borjas, George J. and Stephen Trejo. 1991. “Immigration Participation in the Welfare System.” Industrial and Labor Relations Review 44(2): 195-211.

Bound, John, Charles Brown, and Nancy Mathiowetz. 1999. "Measurement Error in Survey Data.” In Handbook of Econometrics 4, ed. James Heckman and Ed Leamer. New York: Springer-Verlag.

Cawley, John. 2000. “Body Weight and Women’s Labor Market Outcomes.” NBER Working Paper No. 7841.

Chen, Jiajian, Edward Ng, and Russell Wilkins. 1996. “The Health of Canada’s Immigrants in 99495.” Health Reports 7(4): 33-45.

Chiswick, Barry R. 1986. “Is the New Immigration Less Skilled than the Old?” Journal of Labor Economics 4(2): 168-192.

Chou, Shin-Yi, Michael Grossman, and Henry Saffer. 2002. “An Economic Analysis of Adult Obesity: Results from the Behavioral Risk Factor Surveillance System.” NBER Working Paper No. 9247.

Costa, Dora L. and Richard H. Steckel. 1995. "Long-Term Trends in Health, Welfare, and Economic Growth in the United States.” NBER Historical Working Paper No. 76.

Cutler, David M., Edward L. Glaeser, and Jesse M. Shapiro. 2003. "Why Have Americans Become More Obese?” NBER Working Paper No. 9446. 
Deri, Catherine. 2003. "Understanding the "Healthy Immigrant Effect” In Canada.” Unpublished Manuscript.

Donovan, J., E. d'Espaignet, C. Metron, and M. van Ommeren, eds. 1992 Immigrants in Australia: A Health Profile, Australian Institute of Health and Welfare Ethnic Health Series, No 1. Canberra: AGPS.

Duleep, Harriet Orcutt and Mark C. Regets. 1994. "The Elusive Concept of Immigrant Quality.” Urban Institute (Washington, DC) Working Paper No. PRIP-UI-28. . 1999. "Immigrants and Human Capital Investment?” American Economic Review 89(2): 186-191. . 2002 “The Elusive Concept of Immigrant Quality: Evidence from 1970-1990.” Forschungsinstitut zur Zukunft der Arbiet (IZA), Discussion Paper, No. 631.

Funkhouser, Edward and Stephen J. Trejo. 1995. "The Labor Market Skills of Recent Male Immigrants: Evidence from the Current Population Survey.” Industrial and Labor Relations Review 48(4): 792-811.

Gordon-Larsen, Penny, Kathleen Mullan Harris, Dianne S. Ward, and Barry M. Popkin. 2003. "Acculturation and Overweight-Related Behaviors Among Hispanic Immigrants to the US: The National Longitudinal Study of Adolescent Health.” Social Science and Medicine 57: 2023-2034.

Hamermesh, Daniel S. and Jeff E. Biddle. 1994. "Beauty and the Labor Market.” American Economic Review 84(5): 1174-1194.

Himes, Christine. 2000. "Obesity, Disease, and Functional Limitation in Later Life.” Demography 37(1): 73-82.

House, James S., Ronald C. Kessler, A Regula Herzog, Richard P. Mero, Ann M. Kinney, and Martha J. Breslow. 1990. “Age, Socioeconomic Status and Health.” The Milbank Quarterly 68(3): 383-411.

Hu, Wei-Yin. 2000. "Immigrant Earning Assimilation: Estimates from Longitudinal Data.” American Economic Review 90(2): 368-372.

Jasso, Guillermina, Douglas S. Massey, Mark R. Rosenzweig, and James P. Smith. 2004. "Immigrant Health - Selectivity and Acculturation.” RAND Unpublished Manuscript.

Kasl, Stanislav V. and Lisa Berkman. 1983. "Health Consequences of The Experiences of Migration,” Annual Review of Public Health 4: 69-90. 
LaLonde, Robert J. and Robert H. Topel. 1992. "The Assimilation of Immigrants in the U.S. Labor Market.” In George J. Borjas and Richard B. Freeman , eds., Immigration and the Work Force: Economic Consequences for the United States and Source Areas. Chicago: University of Chicago Press: 67-92.

Lakdawalla, Darius and Tomas Philipson. 2002. "The Growth of Obesity and Technological Change: A Theoretical and Empirical Examination.” NBER Working Paper No. 8946.

Laroche, Mireille. 2000. "Health Status and Health Services Utilization of Canada’s Immigrant and Non-Immigrant Populations.” Canadian Public Policy 26(2): 51-75.

Leclere, Felicia B., Leif Jensen, and Ann E. Biddlecom. 1994. "Health Care Utilization, Family Context, and Adaptation Among Immigrants to the United States." Journal of Health and Social Behavior 35(4): 370-384.

Lee, Lung-fei and Jungsywan H. Sepanski. 1995. "Estimation of Linear and Nonlinear Errors in Variables Models Using Validation Data.” Journal of the American Statistical Association 90(429): 130-140.

Marmot, Michael G. and S. Leonard Syme. 1976. "Acculturation and Coronary Heart Disease in Japanese- Americans.” American Journal of Epidemiology 104(3): 225 -247.

Marmot, Michael G., A.M. Adelstein and L. Bulusu. 1984. "Lessons from the Study of Immigrant Mortality.” Lancet 30: 1455-1457.

McDonald, James Ted and Steven Kennedy. 2004. "Insights into the 'Healthy Immigrant Effect': Health Status and Health Service Use of Immigrants to Canada." Social Science and Medicine 59(8): 1613-1627.

McDonald, James Ted. 2003. “The Health of Immigrants to Canada.” mimeo University of New Brunswick.

McDonald, James Ted. 2004. "BMI and the Incidence of being Overweight and Obese among Canadian Immigrants: Is Acculturation Associated with Unhealthy Weight Gain?” mimeo, University of New Brunswick.

National Vital Statistics Reports. 2003. 52(3): 42.

OECD. 2000. Health Data. Paris: OECD Publications.

Pagan, Jose A. and Alberto Davila. 1997. "Obesity, Occupational Attainment, and Earnings.” Social Science Quarterly 78(3): 756-770.

Palloni, Alberto, and Elizabeth Arias. 2003. "A Re-Examination of the Hispanic Mortality Paradox.” CDE Working Paper No. 2003-01. 
Perez, Claudio E. 2002. "Health Status and Health Behaviour Among Immigrants.” Health Reports 13(Suppl.): 1-12.

Philipson, Tomas. 2001. “The World-Wide Growth in Obesity: An Economic Research Agenda.” Health Economics 10(1): 1-7.

Philipson, Tomas and Richard A. Posner. 1999. "The Long-Run Growth in Obesity as a Function of Technological Change.” NBER Working Paper No. 7423.

Popkin, Barry M. and P. Gordon-Larsen. 2004. "The Nutrition Transition: Worldwide Obesity Dynamics and the Determinant.” International Journal of Obesity 28: S2-S9.

Register, Charles A. and Donald R. Williams. 1990. "Wage Effects of Obesity among Young Workers.” Social Science Quarterly 71(1): 130-141.

Schoeni, Robert F. 1997. "New Evidence on the Economic Progress of Foreign-Born Men in the 1970s and 1980s.” Journal of Human Resources 32(4): 683-740.

. 1998. "Labor Market Assimilation of Immigrant Women.” Industrial and Labor Relations Review 51(3): 483-504.

Sorlie, Paul D., Eric Backlund, Norman J. Johnson, and Eugene Rogot. 1993. "Mortality by Hispanic Status in the United States.” Journal of American Medical Association 270(20): 2464-2468.

Stephen, Elizabeth Hervey, Karen Foote, Gerry E. Hendershot, Charlotte A. Schoenborn. 1994. "Health of the Foreign-Born Population." Advance Data from Vital and Health Statistics 241: 1-10.

Sturm, Roland. 2002. "The Effects of Obesity, Smoking and Drinking on Medical Problems and Costs.” Health Affairs 21(2): 245-53.

Vega, William and Hortensia Amaro. 1994. "Latino Outlook: Good Health, Uncertain Prognosis.” Annual Review of Public Health 15: 39-67.

Wolf, Anne and Graham Colditz. 1998. "Current Estimates of the Economic Cost of Obesity in the United States.” Obesity Research 6(2): 97-106. 
$\mathrm{n}=$ native, $<5=<5$ years in US, and $15+=15+$ years in US

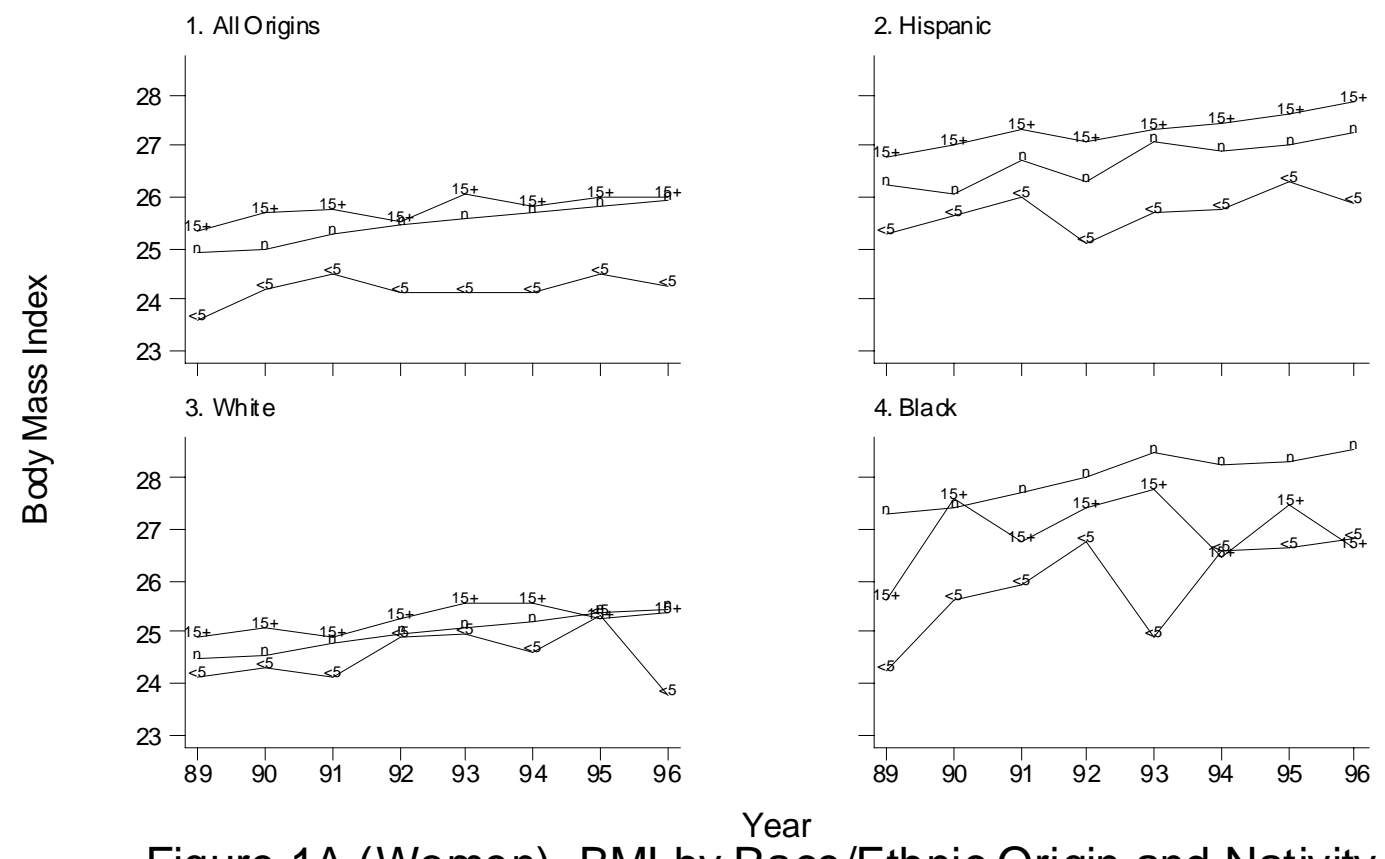

Figure $1 \mathrm{~A}$ (Women). BMI by Race/Ethnic Origin and Nativity
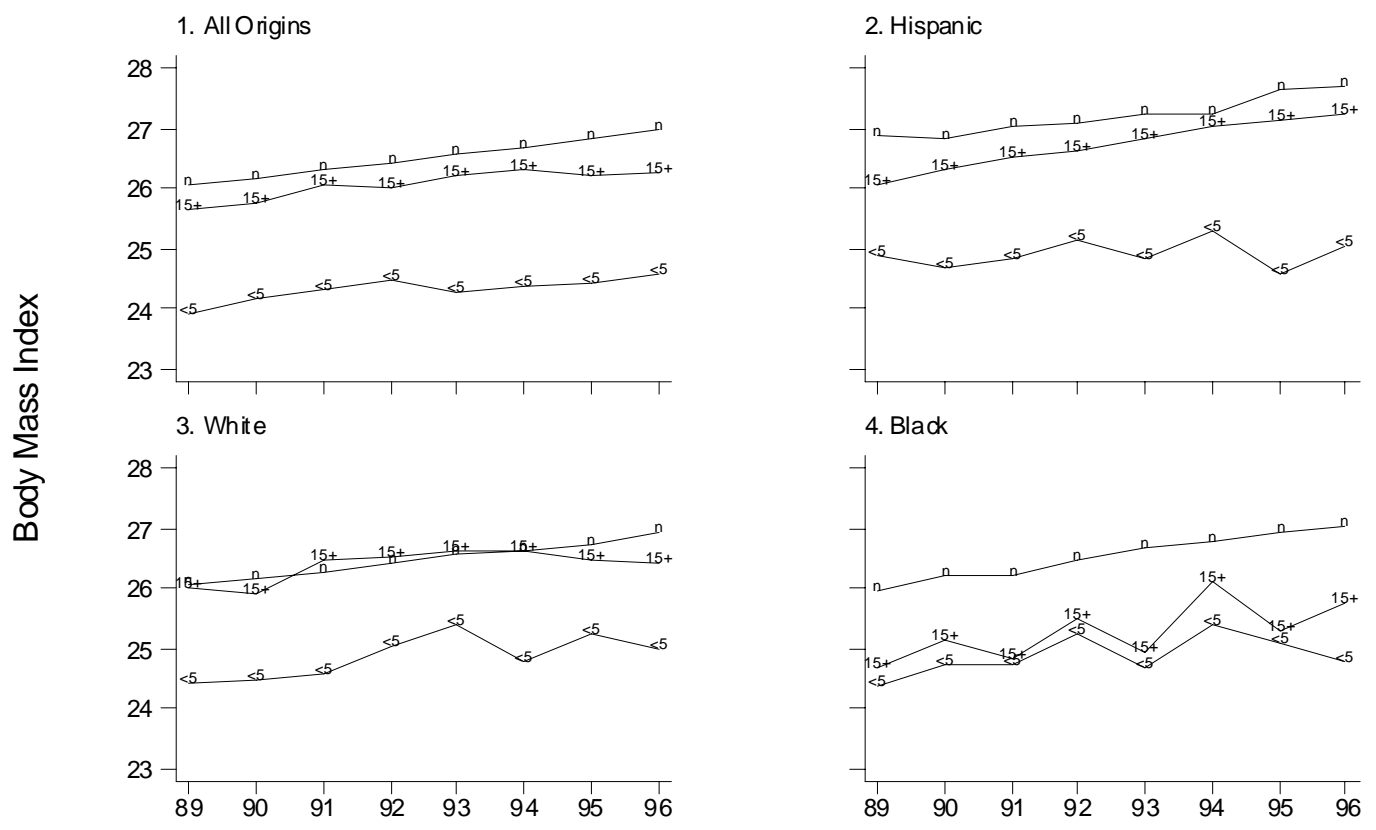

4. Black

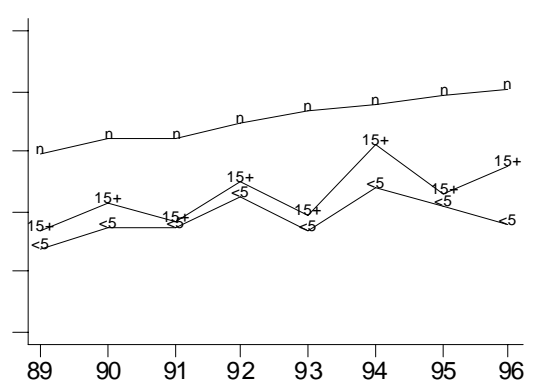

Figure 1B (Men). BMI by Race/Ethnic Origin and Nativity 
$\mathrm{n}=$ native, $<5=<5$ years in US, and $15+=15+$ years in US
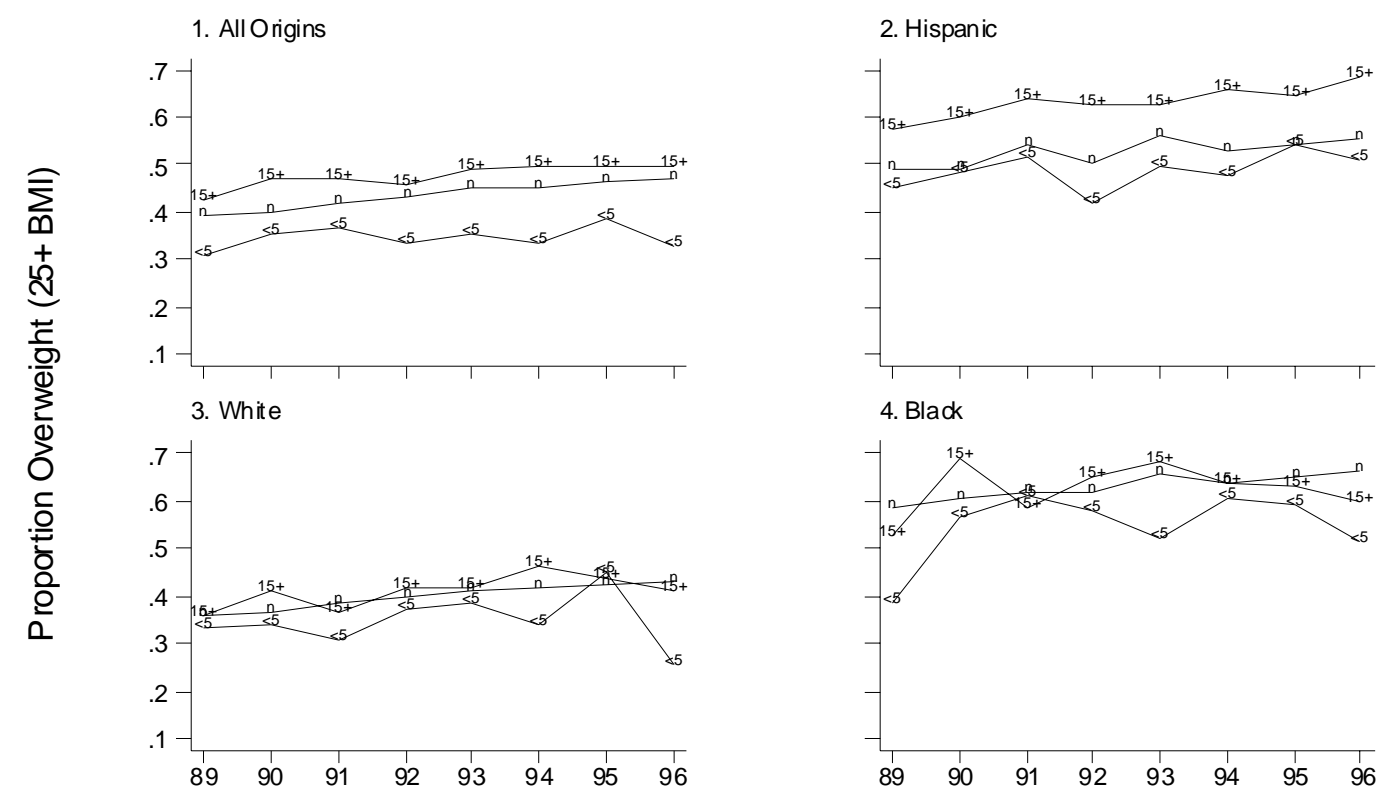

Figure 2A (Women). Overweight by Race/Ethnic Origin and Nativity
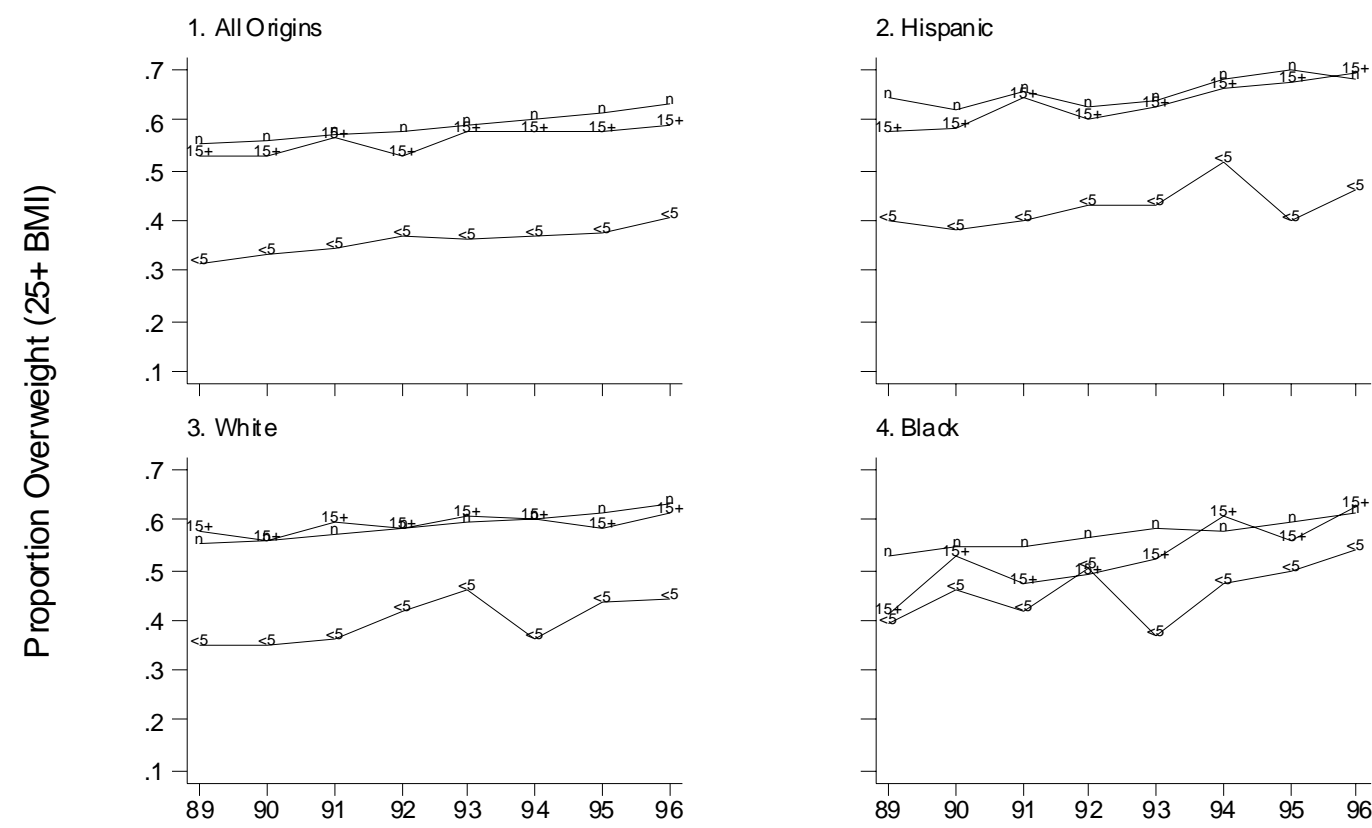

4. Black

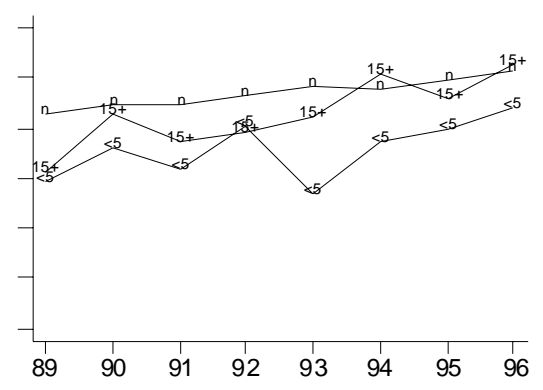

Year

Figure 2B (Men). Overweight by Race/Ethnic Origin and Nativity 
$\mathrm{n}=$ native, $<5=<5$ years in US, and $15+=15+$ years in US
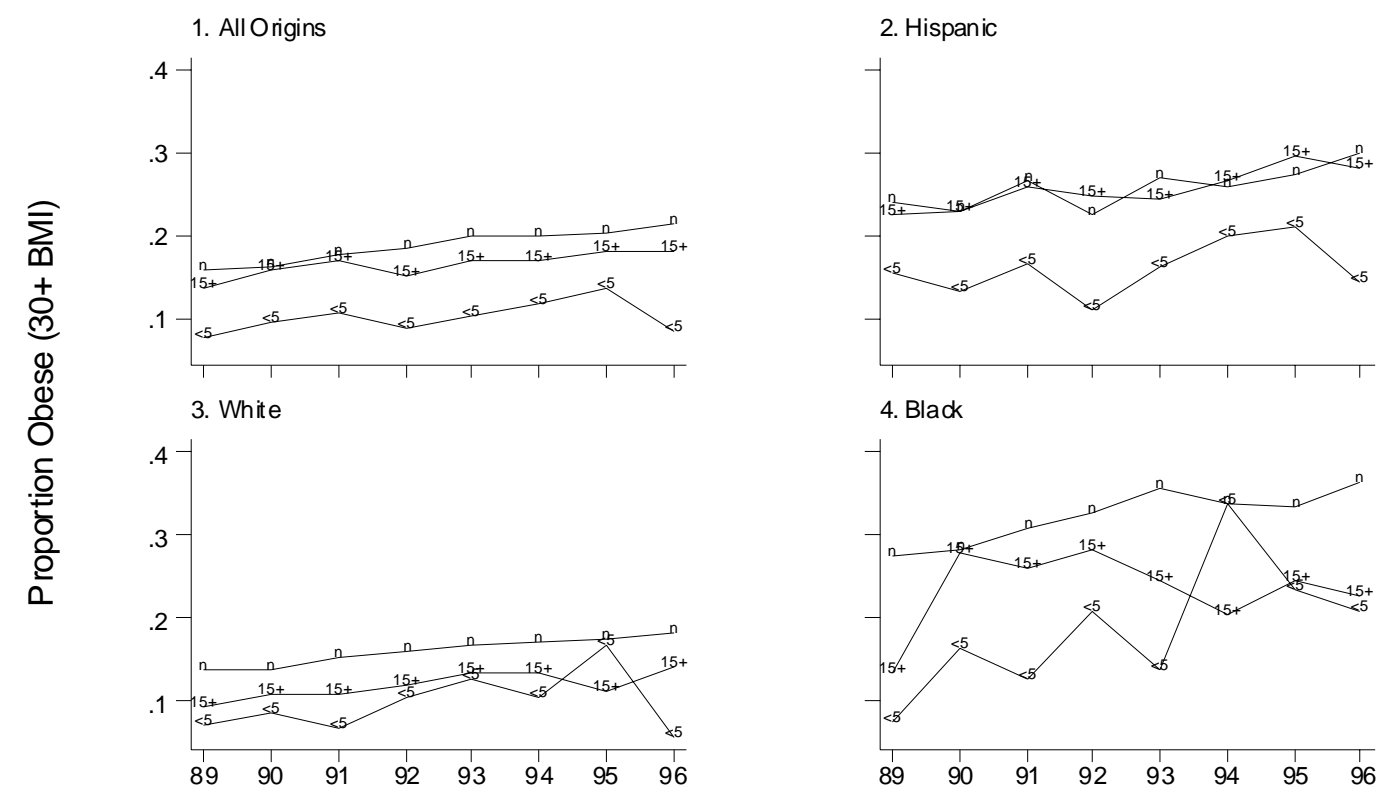

Figure 3A (Women). Obesity by Race/Ethnic Origin and Nativity

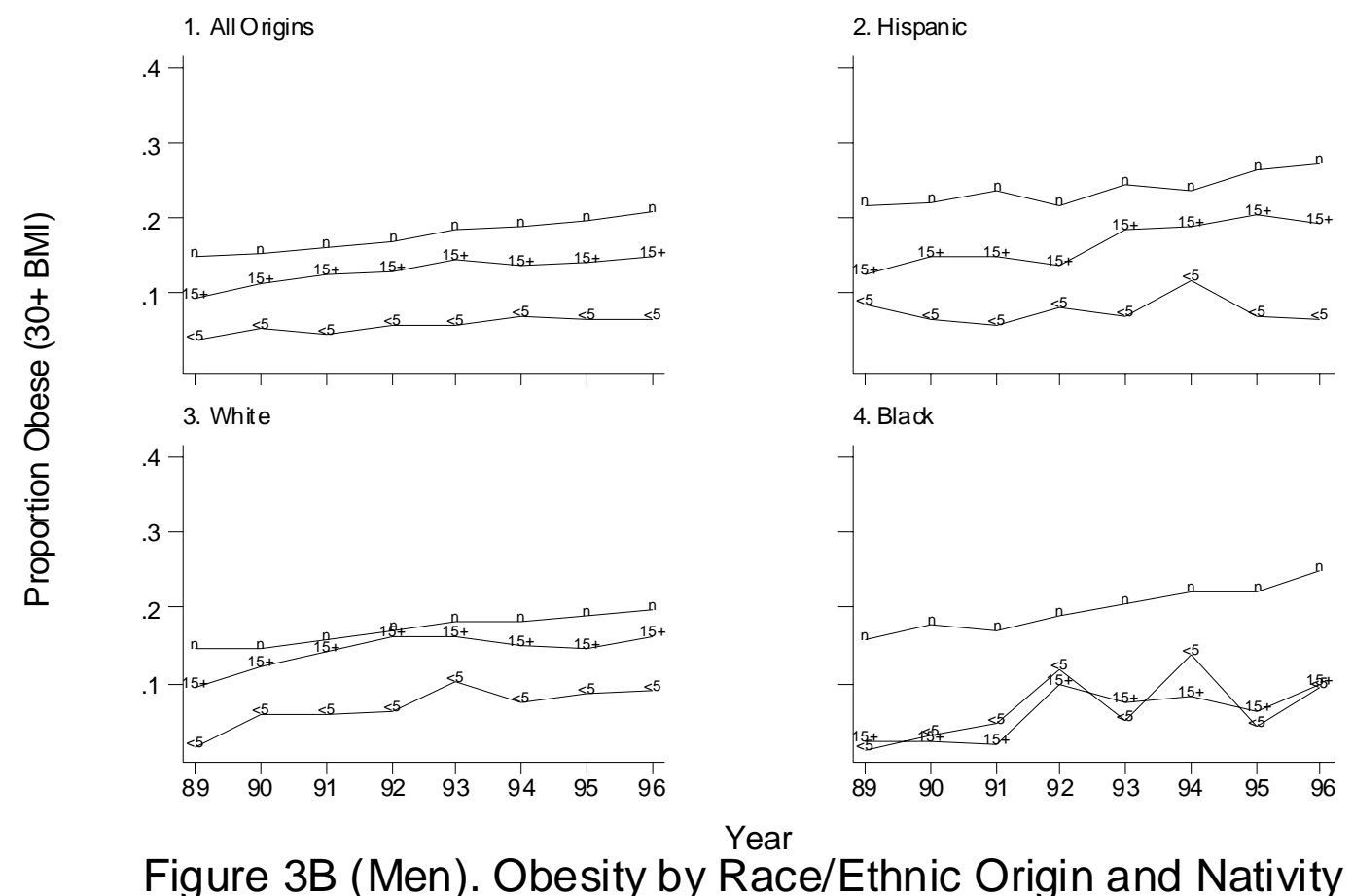


Table 1a. Summary Statistics for Women by Nativity and Race/Ethnic Origin

\begin{tabular}{|c|c|c|c|c|c|c|c|c|}
\hline & \multicolumn{2}{|c|}{ All Origins } & \multicolumn{2}{|c|}{ Hispanic } & \multicolumn{2}{|c|}{ White } & \multicolumn{2}{|c|}{ Black } \\
\hline & Nat & Imm & Nat & Imm & Nat & Imm & Nat & Imm \\
\hline Poor Health & $\begin{array}{c}0.105 \\
(0.306)\end{array}$ & $\begin{array}{c}0.122 \\
(0.327)\end{array}$ & $\begin{array}{c}0.145 \\
(0.352)\end{array}$ & $\begin{array}{c}0.163 \\
(0.369)\end{array}$ & $\begin{array}{c}0.088 \\
(0.284)\end{array}$ & $\begin{array}{c}0.100 \\
(0.300)\end{array}$ & $\begin{array}{c}0.191 \\
(0.393)\end{array}$ & $\begin{array}{c}0.099 \\
(0.298)\end{array}$ \\
\hline Health Conditions & $\begin{array}{c}0.460 \\
(0.498)\end{array}$ & $\begin{array}{c}0.340 \\
(0.474)\end{array}$ & $\begin{array}{c}0.410 \\
(0.492)\end{array}$ & $\begin{array}{c}0.341 \\
(0.474)\end{array}$ & $\begin{array}{c}0.465 \\
(0.499)\end{array}$ & $\begin{array}{c}0.392 \\
(0.488)\end{array}$ & $\begin{array}{c}0.445 \\
(0.497)\end{array}$ & $\begin{array}{c}0.310 \\
(0.462)\end{array}$ \\
\hline Activity Limitations & $\begin{array}{c}0.149 \\
(0.356)\end{array}$ & $\begin{array}{c}0.108 \\
(0.311)\end{array}$ & $\begin{array}{c}0.132 \\
(0.339)\end{array}$ & $\begin{array}{c}0.121 \\
(0.327)\end{array}$ & $\begin{array}{c}0.145 \\
(0.352)\end{array}$ & $\begin{array}{c}0.124 \\
(0.330)\end{array}$ & $\begin{array}{c}0.175 \\
(0.380)\end{array}$ & $\begin{array}{c}0.084 \\
(0.277)\end{array}$ \\
\hline Poverty & $\begin{array}{c}0.103 \\
(0.304)\end{array}$ & $\begin{array}{c}0.187 \\
(0.390)\end{array}$ & $\begin{array}{c}0.206 \\
(0.404)\end{array}$ & $\begin{array}{c}0.322 \\
(0.467)\end{array}$ & $\begin{array}{c}0.071 \\
(0.257)\end{array}$ & $\begin{array}{c}0.091 \\
(0.287)\end{array}$ & $\begin{array}{c}0.277 \\
(0.447)\end{array}$ & $\begin{array}{c}0.165 \\
(0.371)\end{array}$ \\
\hline BMI & $\begin{array}{l}25.459 \\
(5.808)\end{array}$ & $\begin{array}{l}25.259 \\
(4.842)\end{array}$ & $\begin{array}{l}26.739 \\
(6.222)\end{array}$ & $\begin{array}{l}26.817 \\
(4.876)\end{array}$ & $\begin{array}{l}24.980 \\
(5.497)\end{array}$ & $\begin{array}{l}25.015 \\
(4.494)\end{array}$ & $\begin{array}{l}28.018 \\
(6.646)\end{array}$ & $\begin{array}{l}26.689 \\
(5.204)\end{array}$ \\
\hline Overweight (BMI 25+) & $\begin{array}{c}0.435 \\
(0.496)\end{array}$ & $\begin{array}{c}0.438 \\
(0.496)\end{array}$ & $\begin{array}{c}0.529 \\
(0.499)\end{array}$ & $\begin{array}{c}0.593 \\
(0.491)\end{array}$ & $\begin{array}{c}0.400 \\
(0.490)\end{array}$ & $\begin{array}{c}0.393 \\
(0.488)\end{array}$ & $\begin{array}{c}0.630 \\
(0.483)\end{array}$ & $\begin{array}{c}0.594 \\
(0.491)\end{array}$ \\
\hline Obese (BMI 30+) & $\begin{array}{c}0.186 \\
(0.389)\end{array}$ & $\begin{array}{c}0.145 \\
(0.352)\end{array}$ & $\begin{array}{c}0.261 \\
(0.439)\end{array}$ & $\begin{array}{l}0.225 \\
(0.417)\end{array}$ & $\begin{array}{c}0.161 \\
(0.367)\end{array}$ & $\begin{array}{c}0.112 \\
(0.315)\end{array}$ & $\begin{array}{c}0.324 \\
(0.468)\end{array}$ & $\begin{array}{c}0.221 \\
(0.415)\end{array}$ \\
\hline Immigrated 1980 or Before & & $\begin{array}{c}0.562 \\
(0.496)\end{array}$ & & $\begin{array}{c}0.564 \\
(0.496)\end{array}$ & & $\begin{array}{c}0.670 \\
(0.470)\end{array}$ & & $\begin{array}{c}0.509 \\
(0.500)\end{array}$ \\
\hline Immigrated 1981-85 & & $\begin{array}{c}0.158 \\
(0.365)\end{array}$ & & $\begin{array}{c}0.162 \\
(0.368)\end{array}$ & & $\begin{array}{c}0.110 \\
(0.313)\end{array}$ & & $\begin{array}{c}0.205 \\
(0.404)\end{array}$ \\
\hline Immigrated 1986-90 & & $\begin{array}{c}0.182 \\
(0.386)\end{array}$ & & $\begin{array}{c}0.183 \\
(0.387)\end{array}$ & & $\begin{array}{c}0.139 \\
(0.346)\end{array}$ & & $\begin{array}{c}0.207 \\
(0.405)\end{array}$ \\
\hline Immigrated 1991-96 & & $\begin{array}{c}0.098 \\
(0.298)\end{array}$ & & $\begin{array}{c}0.091 \\
(0.287)\end{array}$ & & $\begin{array}{c}0.080 \\
(0.272)\end{array}$ & & $\begin{array}{c}0.080 \\
(0.271)\end{array}$ \\
\hline 0-4 Years Since Arrival & & $\begin{array}{c}0.187 \\
(0.390)\end{array}$ & & $\begin{array}{c}0.173 \\
(0.379)\end{array}$ & & $\begin{array}{c}0.150 \\
(0.357)\end{array}$ & & $\begin{array}{c}0.173 \\
(0.378)\end{array}$ \\
\hline 5-9 Years Since Arrival & & $\begin{array}{c}0.170 \\
(0.375)\end{array}$ & & $\begin{array}{c}0.178 \\
(0.383)\end{array}$ & & $\begin{array}{c}0.125 \\
(0.331)\end{array}$ & & $\begin{array}{c}0.215 \\
(0.411)\end{array}$ \\
\hline 10-14 Years Since Arrival & & $\begin{array}{c}0.154 \\
(0.361)\end{array}$ & & $\begin{array}{c}0.165 \\
(0.372)\end{array}$ & & $\begin{array}{c}0.104 \\
(0.306)\end{array}$ & & $\begin{array}{c}0.192 \\
(0.394)\end{array}$ \\
\hline 15+ Years Since Arrival & & $\begin{array}{c}0.489 \\
(0.500)\end{array}$ & & $\begin{array}{c}0.483 \\
(0.500)\end{array}$ & & $\begin{array}{c}0.621 \\
(0.485)\end{array}$ & & $\begin{array}{c}0.420 \\
(0.494)\end{array}$ \\
\hline Age & $\begin{array}{c}39.423 \\
(12.132)\end{array}$ & $\begin{array}{c}38.747 \\
(11.817)\end{array}$ & $\begin{array}{c}35.138 \\
(11.510)\end{array}$ & $\begin{array}{c}37.203 \\
(11.517)\end{array}$ & $\begin{array}{c}39.876 \\
(12.129)\end{array}$ & $\begin{array}{c}41.383 \\
(12.130)\end{array}$ & $\begin{array}{c}38.064 \\
(11.972)\end{array}$ & $\begin{array}{c}36.912 \\
(10.950)\end{array}$ \\
\hline Married & $\begin{array}{c}0.661 \\
(0.473)\end{array}$ & $\begin{array}{c}0.679 \\
(0.467)\end{array}$ & $\begin{array}{c}0.590 \\
(0.492)\end{array}$ & $\begin{array}{c}0.663 \\
(0.473)\end{array}$ & $\begin{array}{c}0.709 \\
(0.454)\end{array}$ & $\begin{array}{c}0.729 \\
(0.444)\end{array}$ & $\begin{array}{c}0.391 \\
(0.488)\end{array}$ & $\begin{array}{c}0.461 \\
(0.499)\end{array}$ \\
\hline Years of Education & $\begin{array}{l}13.064 \\
(2.467)\end{array}$ & $\begin{array}{l}11.743 \\
(4.140)\end{array}$ & $\begin{array}{l}11.932 \\
(2.850)\end{array}$ & $\begin{array}{c}9.581 \\
(4.247)\end{array}$ & $\begin{array}{l}13.220 \\
(2.407)\end{array}$ & $\begin{array}{l}12.879 \\
(3.365)\end{array}$ & $\begin{array}{l}12.452 \\
(2.480)\end{array}$ & $\begin{array}{l}12.485 \\
(3.159)\end{array}$ \\
\hline Working/Employed & $\begin{array}{c}0.675 \\
(0.469)\end{array}$ & $\begin{array}{c}0.567 \\
(0.496)\end{array}$ & $\begin{array}{c}0.617 \\
(0.486)\end{array}$ & $\begin{array}{c}0.473 \\
(0.499)\end{array}$ & $\begin{array}{c}0.686 \\
(0.464)\end{array}$ & $\begin{array}{c}0.600 \\
(0.490)\end{array}$ & $\begin{array}{c}0.628 \\
(0.483)\end{array}$ & $\begin{array}{c}0.701 \\
(0.458)\end{array}$ \\
\hline Urban & $\begin{array}{c}0.776 \\
(0.417)\end{array}$ & $\begin{array}{c}0.941 \\
(0.236)\end{array}$ & $\begin{array}{c}0.904 \\
(0.295)\end{array}$ & $\begin{array}{c}0.950 \\
(0.218)\end{array}$ & $\begin{array}{c}0.758 \\
(0.428)\end{array}$ & $\begin{array}{c}0.912 \\
(0.283)\end{array}$ & $\begin{array}{c}0.854 \\
(0.353)\end{array}$ & $\begin{array}{c}0.988 \\
(0.110)\end{array}$ \\
\hline Sample Size & 226,611 & 32,107 & 11034 & 13548 & 176853 & 9388 & 35642 & 2446 \\
\hline
\end{tabular}

NHIS data from 1989-96 for individuals aged 20-64. All statistics use NHIS annual weights. Sample size is based on activity limitation reports, since it has the highest reporting rate. Standard deviations in parentheses. 
Table 1b. Summary Statistics for Men by Nativity and Race/Ethnic Origin

\begin{tabular}{|c|c|c|c|c|c|c|c|c|}
\hline & \multicolumn{2}{|c|}{ All Origins } & \multicolumn{2}{|c|}{ Hispanic } & \multicolumn{2}{|c|}{ White } & \multicolumn{2}{|c|}{ Black } \\
\hline & Nat & Imm & Nat & Imm & Nat & Imm & Nat & Imm \\
\hline Poor Health & $\begin{array}{c}0.089 \\
(0.285)\end{array}$ & $\begin{array}{c}0.085 \\
(0.280)\end{array}$ & $\begin{array}{c}0.106 \\
(0.307)\end{array}$ & $\begin{array}{c}0.110 \\
(0.313)\end{array}$ & $\begin{array}{c}0.080 \\
(0.271)\end{array}$ & $\begin{array}{c}0.076 \\
(0.264)\end{array}$ & $\begin{array}{c}0.149 \\
(0.356)\end{array}$ & $\begin{array}{c}0.044 \\
(0.205)\end{array}$ \\
\hline Health Conditions & $\begin{array}{c}0.395 \\
(0.489)\end{array}$ & $\begin{array}{c}0.262 \\
(0.440)\end{array}$ & $\begin{array}{c}0.339 \\
(0.473)\end{array}$ & $\begin{array}{c}0.246 \\
(0.430)\end{array}$ & $\begin{array}{c}0.403 \\
(0.490)\end{array}$ & $\begin{array}{c}0.315 \\
(0.464)\end{array}$ & $\begin{array}{c}0.358 \\
(0.480)\end{array}$ & $\begin{array}{c}0.222 \\
(0.415)\end{array}$ \\
\hline Activity Limitations & $\begin{array}{c}0.144 \\
(0.351)\end{array}$ & $\begin{array}{c}0.090 \\
(0.286)\end{array}$ & $\begin{array}{c}0.126 \\
(0.332)\end{array}$ & $\begin{array}{c}0.096 \\
(0.295)\end{array}$ & $\begin{array}{c}0.140 \\
(0.347)\end{array}$ & $\begin{array}{c}0.104 \\
(0.305)\end{array}$ & $\begin{array}{c}0.174 \\
(0.379)\end{array}$ & $\begin{array}{c}0.062 \\
(0.242)\end{array}$ \\
\hline Poverty & $\begin{array}{c}0.070 \\
(0.255)\end{array}$ & $\begin{array}{c}0.161 \\
(0.367)\end{array}$ & $\begin{array}{c}0.133 \\
(0.339)\end{array}$ & $\begin{array}{c}0.268 \\
(0.443)\end{array}$ & $\begin{array}{c}0.054 \\
(0.226)\end{array}$ & $\begin{array}{c}0.080 \\
(0.271)\end{array}$ & $\begin{array}{c}0.167 \\
(0.373)\end{array}$ & $\begin{array}{c}0.124 \\
(0.330)\end{array}$ \\
\hline BMI & $\begin{array}{l}26.504 \\
(4.490)\end{array}$ & $\begin{array}{l}25.367 \\
(3.826)\end{array}$ & $\begin{array}{l}27.233 \\
(4.803)\end{array}$ & $\begin{array}{l}26.024 \\
(4.091)\end{array}$ & $\begin{array}{l}26.475 \\
(4.390)\end{array}$ & $\begin{array}{l}25.878 \\
(3.804)\end{array}$ & $\begin{array}{l}26.540 \\
(5.008)\end{array}$ & $\begin{array}{l}25.055 \\
(3.163)\end{array}$ \\
\hline Overweight (BMI 25+) & $\begin{array}{c}0.589 \\
(0.492)\end{array}$ & $\begin{array}{c}0.485 \\
(0.500)\end{array}$ & $\begin{array}{c}0.661 \\
(0.473)\end{array}$ & $\begin{array}{c}0.565 \\
(0.496)\end{array}$ & $\begin{array}{c}0.590 \\
(0.492)\end{array}$ & $\begin{array}{c}0.540 \\
(0.498)\end{array}$ & $\begin{array}{c}0.570 \\
(0.495)\end{array}$ & $\begin{array}{c}0.492 \\
(0.500)\end{array}$ \\
\hline Obese (BMI 30+) & $\begin{array}{c}0.177 \\
(0.382)\end{array}$ & $\begin{array}{c}0.097 \\
(0.297)\end{array}$ & $\begin{array}{c}0.241 \\
(0.428)\end{array}$ & $\begin{array}{c}0.129 \\
(0.336)\end{array}$ & $\begin{array}{c}0.171 \\
(0.377)\end{array}$ & $\begin{array}{c}0.116 \\
(0.320)\end{array}$ & $\begin{array}{c}0.199 \\
(0.399)\end{array}$ & $\begin{array}{c}0.059 \\
(0.236)\end{array}$ \\
\hline Immigrated 1980 or Before & & $\begin{array}{c}0.534 \\
(0.499)\end{array}$ & & $\begin{array}{c}0.531 \\
(0.499)\end{array}$ & & $\begin{array}{c}0.626 \\
(0.484)\end{array}$ & & $\begin{array}{c}0.492 \\
(0.500)\end{array}$ \\
\hline Immigrated 1981-85 & & $\begin{array}{c}0.179 \\
(0.384)\end{array}$ & & $\begin{array}{c}0.184 \\
(0.388)\end{array}$ & & $\begin{array}{c}0.129 \\
(0.335)\end{array}$ & & $\begin{array}{c}0.232 \\
(0.422)\end{array}$ \\
\hline Immigrated 1986-90 & & $\begin{array}{c}0.193 \\
(0.394)\end{array}$ & & $\begin{array}{c}0.201 \\
(0.401)\end{array}$ & & $\begin{array}{c}0.158 \\
(0.365)\end{array}$ & & $\begin{array}{c}0.202 \\
(0.402)\end{array}$ \\
\hline Immigrated 1991-96 & & $\begin{array}{c}0.094 \\
(0.292)\end{array}$ & & $\begin{array}{c}0.084 \\
(0.277)\end{array}$ & & $\begin{array}{c}0.087 \\
(0.282)\end{array}$ & & $\begin{array}{c}0.074 \\
(0.262)\end{array}$ \\
\hline 0-4 Years Since Arrival & & $\begin{array}{c}0.185 \\
(0.388)\end{array}$ & & $\begin{array}{c}0.173 \\
(0.378)\end{array}$ & & $\begin{array}{c}0.163 \\
(0.369)\end{array}$ & & $\begin{array}{c}0.162 \\
(0.368)\end{array}$ \\
\hline 5-9 Years Since Arrival & & $\begin{array}{c}0.189 \\
(0.391)\end{array}$ & & $\begin{array}{c}0.201 \\
(0.401)\end{array}$ & & $\begin{array}{c}0.146 \\
(0.353)\end{array}$ & & $\begin{array}{c}0.228 \\
(0.420)\end{array}$ \\
\hline 10-14 Years Since Arrival & & $\begin{array}{c}0.172 \\
(0.378)\end{array}$ & & $\begin{array}{c}0.182 \\
(0.386)\end{array}$ & & $\begin{array}{c}0.126 \\
(0.332)\end{array}$ & & $\begin{array}{c}0.220 \\
(0.414)\end{array}$ \\
\hline 15+ Years Since Arrival & & $\begin{array}{c}0.454 \\
(0.498)\end{array}$ & & $\begin{array}{c}0.444 \\
(0.497)\end{array}$ & & $\begin{array}{c}0.565 \\
(0.496)\end{array}$ & & $\begin{array}{c}0.391 \\
(0.488)\end{array}$ \\
\hline Age & $\begin{array}{c}39.306 \\
(12.005)\end{array}$ & $\begin{array}{c}37.692 \\
(11.493)\end{array}$ & $\begin{array}{c}34.922 \\
(11.459)\end{array}$ & $\begin{array}{c}36.157 \\
(11.243)\end{array}$ & $\begin{array}{c}39.723 \\
(11.967)\end{array}$ & $\begin{array}{c}39.988 \\
(11.789)\end{array}$ & $\begin{array}{c}37.942 \\
(12.020)\end{array}$ & $\begin{array}{c}36.508 \\
(10.177)\end{array}$ \\
\hline Married & $\begin{array}{c}0.688 \\
(0.463)\end{array}$ & $\begin{array}{c}0.687 \\
(0.464)\end{array}$ & $\begin{array}{c}0.611 \\
(0.488)\end{array}$ & $\begin{array}{c}0.697 \\
(0.459)\end{array}$ & $\begin{array}{c}0.713 \\
(0.452)\end{array}$ & $\begin{array}{c}0.711 \\
(0.453)\end{array}$ & $\begin{array}{c}0.540 \\
(0.498)\end{array}$ & $\begin{array}{c}0.601 \\
(0.490)\end{array}$ \\
\hline Years of Education & $\begin{array}{l}13.196 \\
(2.694)\end{array}$ & $\begin{array}{l}12.109 \\
(4.285)\end{array}$ & $\begin{array}{l}12.214 \\
(2.825)\end{array}$ & $\begin{array}{c}9.473 \\
(4.272)\end{array}$ & $\begin{array}{l}13.372 \\
(2.647)\end{array}$ & $\begin{array}{l}13.565 \\
(3.447)\end{array}$ & $\begin{array}{l}12.243 \\
(2.701)\end{array}$ & $\begin{array}{l}13.117 \\
(3.140)\end{array}$ \\
\hline Working/Employed & $\begin{array}{c}0.837 \\
(0.369)\end{array}$ & $\begin{array}{c}0.822 \\
(0.383)\end{array}$ & $\begin{array}{c}0.809 \\
(0.393)\end{array}$ & $\begin{array}{c}0.831 \\
(0.375)\end{array}$ & $\begin{array}{c}0.854 \\
(0.353)\end{array}$ & $\begin{array}{c}0.838 \\
(0.368)\end{array}$ & $\begin{array}{c}0.733 \\
(0.442)\end{array}$ & $\begin{array}{c}0.798 \\
(0.401)\end{array}$ \\
\hline Urban & $\begin{array}{c}0.771 \\
(0.420)\end{array}$ & $\begin{array}{c}0.943 \\
(0.232)\end{array}$ & $\begin{array}{c}0.898 \\
(0.302)\end{array}$ & $\begin{array}{c}0.936 \\
(0.245)\end{array}$ & $\begin{array}{c}0.756 \\
(0.429)\end{array}$ & $\begin{array}{c}0.932 \\
(0.251)\end{array}$ & $\begin{array}{c}0.850 \\
(0.357)\end{array}$ & $\begin{array}{c}0.985 \\
(0.120)\end{array}$ \\
\hline Sample Size & 202,871 & 29,217 & 9,476 & 12,948 & 166,046 & 8,405 & 24,537 & 1,993 \\
\hline
\end{tabular}

NHIS data from 1989-96 for individuals aged 20-64. All statistics use NHIS annual weights. Sample size is based on activity limitation reports, since it has the highest reporting rate. Standard deviations in parentheses. 
Table 2a. Immigrant Cohort and Assimilation Effects of Health Status for Women by Race/Ethnic Origin

\begin{tabular}{|c|c|c|c|c|c|c|c|c|c|c|c|c|}
\hline & \multicolumn{3}{|c|}{ All Origins } & \multicolumn{3}{|c|}{ Hispanic } & \multicolumn{3}{|c|}{ White } & \multicolumn{3}{|c|}{ Black } \\
\hline & $\begin{array}{l}\text { Poor } \\
\text { Health }\end{array}$ & $\begin{array}{c}\text { Health } \\
\text { Conditions }\end{array}$ & $\begin{array}{c}\text { Activity } \\
\text { Limitations }\end{array}$ & $\begin{array}{l}\text { Poor } \\
\text { Health }\end{array}$ & $\begin{array}{c}\text { Health } \\
\text { Conditions }\end{array}$ & $\begin{array}{c}\text { Activity } \\
\text { Limitations }\end{array}$ & $\begin{array}{l}\text { Poor } \\
\text { Health }\end{array}$ & $\begin{array}{c}\text { Health } \\
\text { Conditions }\end{array}$ & $\begin{array}{c}\text { Activity } \\
\text { Limitations }\end{array}$ & $\begin{array}{l}\text { Poor } \\
\text { Health }\end{array}$ & $\begin{array}{c}\text { Health } \\
\text { Conditions }\end{array}$ & $\begin{array}{c}\text { Activity } \\
\text { Limitations }\end{array}$ \\
\hline \multicolumn{13}{|l|}{ Cohort Effects } \\
\hline \multicolumn{13}{|l|}{$\overline{\text { Immigrated: }}$} \\
\hline 1980 or Before & $\begin{array}{c}-\mathbf{0 . 0 4 2} \\
(0.009)\end{array}$ & $\begin{array}{c}\mathbf{- 0 . 2 1 2} \\
(0.021)\end{array}$ & $\begin{array}{c}\mathbf{- 0 . 1 0 2} \\
(0.019)\end{array}$ & $\begin{array}{c}\mathbf{- 0 . 0 9 9} \\
(0.024)\end{array}$ & $\begin{array}{c}\mathbf{- 0 . 2 1 4} \\
(0.037)\end{array}$ & $\begin{array}{c}\mathbf{- 0 . 1 0 2} \\
(0.019)\end{array}$ & $\begin{array}{l}-0.014 \\
(0.022)\end{array}$ & $\begin{array}{c}\mathbf{- 0 . 1 7 4} \\
(0.046)\end{array}$ & $\begin{array}{c}\mathbf{- 0 . 0 7 2} \\
(0.020)\end{array}$ & $\begin{array}{l}-0.071 \\
(0.053)\end{array}$ & $\begin{array}{l}-0.090 \\
(0.082)\end{array}$ & $\begin{array}{l}-0.079 \\
(0.034)\end{array}$ \\
\hline 1981-85 & $\begin{array}{c}\mathbf{- 0 . 0 3 8} \\
(0.007)\end{array}$ & $\begin{array}{l}\mathbf{- 0 . 1 9 9} \\
(0.016)\end{array}$ & $\begin{array}{l}-\mathbf{0 . 0 7 4} \\
(0.010)\end{array}$ & $\begin{array}{l}-\mathbf{0 . 0 7 9} \\
(0.014)\end{array}$ & $\begin{array}{l}-\mathbf{0 . 1 7 7} \\
(0.025)\end{array}$ & $\begin{array}{l}-\mathbf{0 . 0 7 4} \\
(0.010)\end{array}$ & $\begin{array}{l}-0.026 \\
(0.013)\end{array}$ & $\begin{array}{l}-\mathbf{0 . 1 7 6} \\
(0.034)\end{array}$ & $\begin{array}{l}\mathbf{- 0 . 0 6 4} \\
(0.017)\end{array}$ & $\begin{array}{l}-0.058 \\
(0.046)\end{array}$ & $\begin{array}{l}-0.097 \\
(0.064)\end{array}$ & $\begin{array}{l}-\mathbf{0 . 0 9 3} \\
(0.018)\end{array}$ \\
\hline 1986-90 & $\begin{array}{c}-0.031 \\
(0.004)\end{array}$ & $\begin{array}{c}\mathbf{- 0 . 2 0 2} \\
(0.009)\end{array}$ & $\begin{array}{c}-\mathbf{0 . 0 7 0} \\
(0.006)\end{array}$ & $\begin{array}{l}-\mathbf{0 . 0 6 7} \\
(0.009)\end{array}$ & $\begin{array}{c}-\mathbf{0 . 1 6 0} \\
(0.015)\end{array}$ & $\begin{array}{c}\mathbf{- 0 . 0 7 0} \\
(0.006)\end{array}$ & $\begin{array}{l}-0.003 \\
(0.010)\end{array}$ & $\begin{array}{c}-\mathbf{0 . 1 6 8} \\
(0.018)\end{array}$ & $\begin{array}{l}-\mathbf{0 . 0 6 3} \\
(0.009)\end{array}$ & $\begin{array}{l}-0.059 \\
(0.030)\end{array}$ & $\begin{array}{l}-\mathbf{0 . 1 6 3} \\
(0.038)\end{array}$ & $\begin{array}{c}\mathbf{- 0 . 0 8 9} \\
(0.013)\end{array}$ \\
\hline 1991-95 & $\begin{array}{l}-\mathbf{- 0 . 0 2 1} \\
(0.005)\end{array}$ & $\begin{array}{c}\mathbf{- 0 . 1 9 1} \\
(0.010)\end{array}$ & $\begin{array}{c}-\mathbf{0 . 0 5 9} \\
(0.007)\end{array}$ & $\begin{array}{c}\mathbf{- 0 . 0 3 9} \\
(0.010)\end{array}$ & $\begin{array}{c}-\mathbf{0 . 1 2 1} \\
(0.016)\end{array}$ & $\begin{array}{l}\mathbf{- 0 . 0 5 9} \\
(0.007)\end{array}$ & $\begin{array}{l}-0.002 \\
(0.010)\end{array}$ & $\begin{array}{c}-\mathbf{0 . 1 6 2} \\
(0.020)\end{array}$ & $\begin{array}{c}\mathbf{- 0 . 0 6 8} \\
(0.008)\end{array}$ & $\begin{array}{c}\mathbf{- 0 . 1 0 2} \\
(0.017)\end{array}$ & $\begin{array}{c}-\mathbf{0 . 1 4 8} \\
(0.040)\end{array}$ & $\begin{array}{c}-\mathbf{0 . 0 9 2} \\
(0.012)\end{array}$ \\
\hline \multicolumn{13}{|c|}{$\frac{\text { Assimilation Effects }}{\text { Years Since Arrival: }}$} \\
\hline $5-9$ & $\begin{array}{c}\mathbf{0 . 0 2 7} \\
(0.011)\end{array}$ & $\begin{array}{c}\mathbf{0 . 0 3 9} \\
(0.016)\end{array}$ & $\begin{array}{c}\mathbf{0 . 0 3 5} \\
(0.019)\end{array}$ & $\begin{array}{c}\mathbf{0 . 0 3 2} \\
(0.019)\end{array}$ & $\begin{array}{c}\mathbf{0 . 0 5 9} \\
(0.025)\end{array}$ & $\begin{array}{c}\mathbf{0 . 0 3 5} \\
(0.019)\end{array}$ & $\begin{array}{c}0.023 \\
(0.020)\end{array}$ & $\begin{array}{c}0.042 \\
(0.032)\end{array}$ & $\begin{array}{c}0.021 \\
(0.027)\end{array}$ & $\begin{array}{c}0.008 \\
(0.055)\end{array}$ & $\begin{array}{c}0.048 \\
(0.059)\end{array}$ & $\begin{array}{c}0.084 \\
(0.063)\end{array}$ \\
\hline $10-14$ & $\begin{array}{c}\mathbf{0 . 0 3 4} \\
(0.016)\end{array}$ & $\begin{array}{c}\mathbf{0 . 0 5 2} \\
(0.023)\end{array}$ & $\begin{array}{c}\mathbf{0 . 0 5 4} \\
(0.031)\end{array}$ & $\begin{array}{c}\mathbf{0 . 0 5 9} \\
(0.032)\end{array}$ & $\begin{array}{c}\mathbf{0 . 0 8 1} \\
(0.038)\end{array}$ & $\begin{array}{c}\mathbf{0 . 0 5 4} \\
(0.031)\end{array}$ & $\begin{array}{c}0.031 \\
(0.031)\end{array}$ & $\begin{array}{c}0.068 \\
(0.048)\end{array}$ & $\begin{array}{c}0.050 \\
(0.043)\end{array}$ & $\begin{array}{c}0.015 \\
(0.076)\end{array}$ & $\begin{array}{c}0.024 \\
(0.079)\end{array}$ & $\begin{array}{c}0.063 \\
(0.081)\end{array}$ \\
\hline $15^{+}$ & $\begin{array}{c}\mathbf{0 . 0 5 3} \\
(0.020)\end{array}$ & $\begin{array}{c}\mathbf{0 . 1 4 0} \\
(0.026)\end{array}$ & $\begin{array}{c}\mathbf{0 . 1 0 1} \\
(0.036)\end{array}$ & $\begin{array}{c}\mathbf{0 . 0 9 6} \\
(0.036)\end{array}$ & $\begin{array}{l}\mathbf{0 . 1 6 7} \\
(0.044)\end{array}$ & $\begin{array}{c}\mathbf{0 . 1 0 1} \\
(0.036)\end{array}$ & $\begin{array}{c}0.010 \\
(0.029)\end{array}$ & $\begin{array}{c}\mathbf{0 . 1 2 5} \\
(0.053)\end{array}$ & $\begin{array}{c}\mathbf{0 . 0 7 5} \\
(0.052)\end{array}$ & $\begin{array}{c}0.035 \\
(0.093)\end{array}$ & $\begin{array}{c}0.000 \\
(0.089)\end{array}$ & $\begin{array}{c}0.070 \\
(0.096)\end{array}$ \\
\hline Sample Size & 257,714 & 258,718 & 24,582 & 24,430 & 24,582 & 24,582 & 185,626 & 186,241 & 186,241 & 37,897 & 38,088 & 38,088 \\
\hline
\end{tabular}

All models also include age, age squared, years of education, and indicators for married, employed, urban, region and survey year. NHIS annual weights used. Marginal effects reported for all probit models.

Standard errors in parentheses. Bold results are statisticaly significant at the $10 \%$ level. Sample size varies due to non-reporting of the dependent variable. 
Table 2b. Immigrant Cohort and Assimilation Effects of Health Status for Men by Race/Ethnic Origin

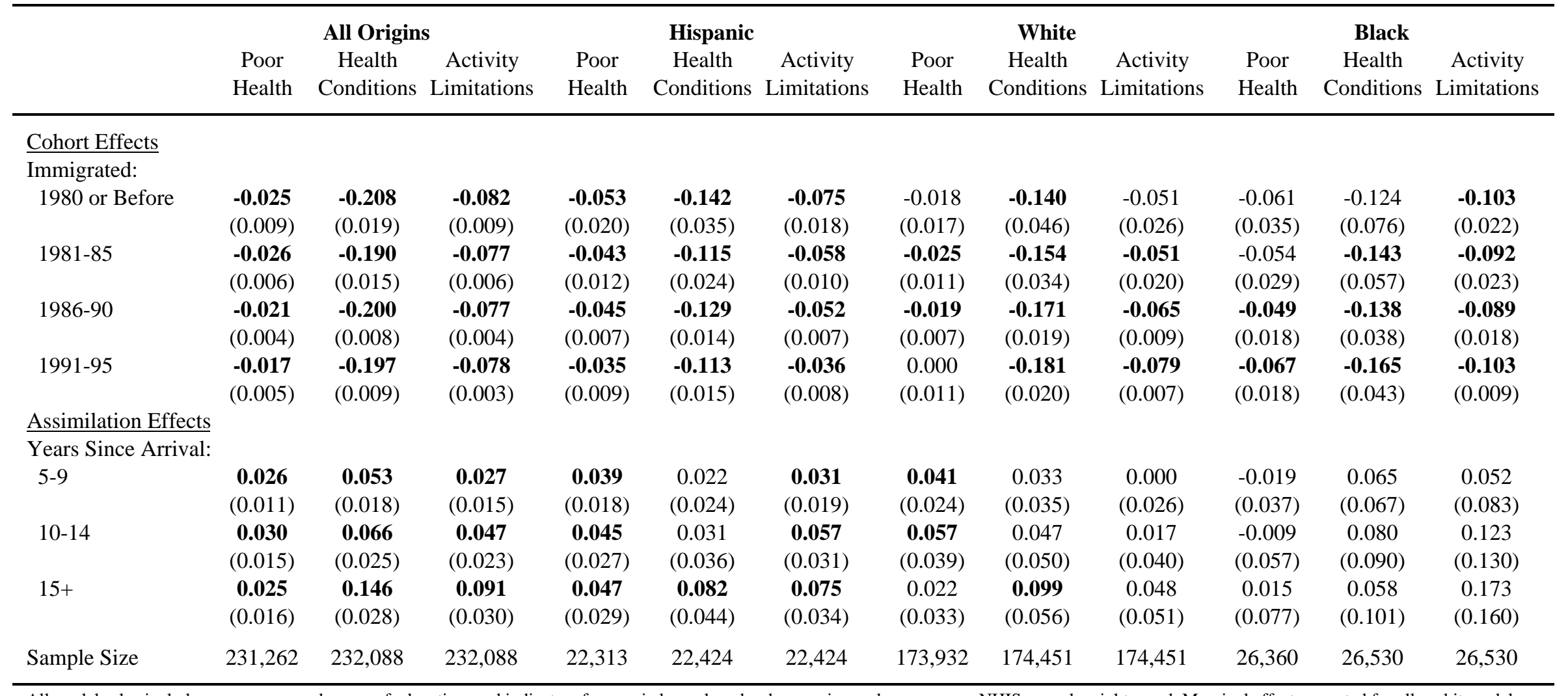

All models also include age, age squared, years of education, and indicators for married, employed, urban, region and survey year. NHIS annual weights used. Marginal effects reported for all probit models.

Standard errors in parentheses. Bold results are statisticaly significant at the $10 \%$ level. Sample size varies due to non-reporting of the dependent variable. 
Table 3a. Immigrant Cohort and Assimilation Effects of BMI for Women by Race/Ethnic Origin

\begin{tabular}{|c|c|c|c|c|c|c|c|c|c|c|c|c|}
\hline & \multicolumn{3}{|c|}{ All Origins } & \multicolumn{3}{|c|}{ Hispanic } & \multicolumn{3}{|c|}{ White } & \multicolumn{3}{|c|}{ Black } \\
\hline & Ln BMI & Overweight & Obese & Ln BMI & Overweight & Obese & Ln BMI & Overweight & Obese & Ln BMI & Overweight & Obese \\
\hline \multicolumn{13}{|l|}{$\underline{\text { Cohort Effects }}$} \\
\hline \multicolumn{13}{|l|}{$\overline{\text { Immigrated: }}$} \\
\hline 1980 or Before & $\begin{array}{c}\mathbf{- 0 . 0 2 5} \\
(0.008)\end{array}$ & $\begin{array}{c}\mathbf{- 0 . 0 9 9} \\
(0.024)\end{array}$ & $\begin{array}{c}\mathbf{- 0 . 0 9 5} \\
(0.013)\end{array}$ & $\begin{array}{c}\mathbf{- 0 . 0 3 7} \\
(0.014)\end{array}$ & $\begin{array}{c}\mathbf{- 0 . 1 1 3} \\
(0.044)\end{array}$ & $\begin{array}{c}\mathbf{- 0 . 1 7 6} \\
(0.030)\end{array}$ & $\begin{array}{c}0.013 \\
(0.015)\end{array}$ & $\begin{array}{c}-0.048 \\
(0.050)\end{array}$ & $\begin{array}{c}-0.053 \\
(0.031)\end{array}$ & $\begin{array}{c}0.010 \\
(0.028)\end{array}$ & $\begin{array}{c}0.016 \\
(0.076)\end{array}$ & $\begin{array}{l}-0.053 \\
(0.075)\end{array}$ \\
\hline 1981-85 & $\begin{array}{c}\mathbf{- 0 . 0 3 4} \\
(0.006)\end{array}$ & $\begin{array}{c}-\mathbf{0 . 0 9 5} \\
(0.018)\end{array}$ & $\begin{array}{c}\mathbf{- 0 . 0 9 9} \\
(0.009)\end{array}$ & $\begin{array}{c}-\mathbf{0 . 0 4 5} \\
(0.010)\end{array}$ & $\begin{array}{c}\mathbf{- 0 . 1 2 0} \\
(0.032)\end{array}$ & $\begin{array}{c}-\mathbf{0 . 1 5 3} \\
(0.017)\end{array}$ & $\begin{array}{c}0.000 \\
(0.012)\end{array}$ & $\begin{array}{c}-0.043 \\
(0.037)\end{array}$ & $\begin{array}{c}\mathbf{- 0 . 0 7 2} \\
(0.019)\end{array}$ & $\begin{array}{l}-0.025 \\
(0.020)\end{array}$ & $\begin{array}{c}0.003 \\
(0.059)\end{array}$ & $\begin{array}{c}\mathbf{- 0 . 1 1 4} \\
(0.049)\end{array}$ \\
\hline 1986-90 & $\begin{array}{l}\mathbf{- 0 . 0 2 5} \\
(0.003)\end{array}$ & $\begin{array}{c}-\mathbf{- 0 . 0 5 8} \\
(0.011)\end{array}$ & $\begin{array}{c}\mathbf{- 0 . 0 8 5} \\
(0.006)\end{array}$ & $\begin{array}{c}\mathbf{- 0 . 0 3 4} \\
(0.006)\end{array}$ & $\begin{array}{c}\mathbf{- 0 . 0 6 9} \\
(0.019)\end{array}$ & $\begin{array}{c}\mathbf{- 0 . 1 2 8} \\
(0.012)\end{array}$ & $\begin{array}{c}\mathbf{0 . 0 1 3} \\
(0.006)\end{array}$ & $\begin{array}{c}0.001 \\
(0.021)\end{array}$ & $\begin{array}{c}\mathbf{- 0 . 0 5 8} \\
(0.012)\end{array}$ & $\begin{array}{c}\mathbf{- 0 . 0 3 9} \\
(0.010)\end{array}$ & $\begin{array}{c}-0.022 \\
(0.036)\end{array}$ & $\begin{array}{c}\mathbf{- 0 . 1 3 7} \\
(0.027)\end{array}$ \\
\hline 1991-95 & $\begin{array}{c}\mathbf{- 0 . 0 4 1} \\
(0.004)\end{array}$ & $\begin{array}{c}\mathbf{- 0 . 0 9 2} \\
(0.011)\end{array}$ & $\begin{array}{c}\mathbf{- 0 . 0 8 7} \\
(0.006)\end{array}$ & $\begin{array}{c}\mathbf{- 0 . 0 4 4} \\
(0.006)\end{array}$ & $\begin{array}{c}\mathbf{- 0 . 0 8 0} \\
(0.019)\end{array}$ & $\begin{array}{c}\mathbf{- 0 . 1 1 5} \\
(0.011)\end{array}$ & $\begin{array}{c}0.007 \\
(0.007)\end{array}$ & $\begin{array}{c}-0.017 \\
(0.021)\end{array}$ & $\begin{array}{c}\mathbf{- 0 . 0 4 2} \\
(0.013)\end{array}$ & $\begin{array}{c}\mathbf{- 0 . 0 5 7} \\
(0.016)\end{array}$ & $\begin{array}{l}-0.055 \\
(0.044)\end{array}$ & $\begin{array}{r}\mathbf{- 0 . 1 0 6} \\
(0.036)\end{array}$ \\
\hline \multicolumn{13}{|c|}{ Assimilation Effects } \\
\hline $5-9$ & $\begin{array}{c}\mathbf{0 . 0 1 7} \\
(0.005)\end{array}$ & $\begin{array}{c}\mathbf{0 . 0 6 6} \\
(0.016)\end{array}$ & $\begin{array}{c}\mathbf{0 . 0 4 3} \\
(0.014)\end{array}$ & $\begin{array}{c}\mathbf{0 . 0 1 9} \\
(0.008)\end{array}$ & $\begin{array}{c}\mathbf{0 . 0 8 1} \\
(0.023)\end{array}$ & $\begin{array}{c}\mathbf{0 . 0 6 4} \\
(0.024)\end{array}$ & $\begin{array}{c}-0.001 \\
(0.009)\end{array}$ & $\begin{array}{c}0.012 \\
(0.031)\end{array}$ & $\begin{array}{c}0.017 \\
(0.027)\end{array}$ & $\begin{array}{c}0.009 \\
(0.017)\end{array}$ & $\begin{array}{l}-0.005 \\
(0.049)\end{array}$ & $\begin{array}{c}0.051 \\
(0.054)\end{array}$ \\
\hline $10-14$ & $\begin{array}{c}\mathbf{0 . 0 1 6} \\
(0.007)\end{array}$ & $\begin{array}{c}\mathbf{0 . 0 8 5} \\
(0.023)\end{array}$ & $\begin{array}{c}\mathbf{0 . 0 6 0} \\
(0.022)\end{array}$ & $\begin{array}{c}\mathbf{0 . 0 2 4} \\
(0.012)\end{array}$ & $\begin{array}{c}\mathbf{0 . 1 1 1} \\
(0.035)\end{array}$ & $\begin{array}{c}\mathbf{0 . 1 1 4} \\
(0.039)\end{array}$ & $\begin{array}{c}-0.002 \\
(0.014)\end{array}$ & $\begin{array}{c}0.040 \\
(0.047)\end{array}$ & $\begin{array}{c}0.002 \\
(0.038)\end{array}$ & $\begin{array}{l}-0.020 \\
(0.025)\end{array}$ & $\begin{array}{c}-0.038 \\
(0.071)\end{array}$ & $\begin{array}{c}0.008 \\
(0.075)\end{array}$ \\
\hline $15+$ & $\begin{array}{c}\mathbf{0 . 0 2 2} \\
(0.008)\end{array}$ & $\begin{array}{c}\mathbf{0 . 0 9 7} \\
(0.026)\end{array}$ & $\begin{array}{c}\mathbf{0 . 0 7 2} \\
(0.025)\end{array}$ & $\begin{array}{c}\mathbf{0 . 0 2 9} \\
(0.015)\end{array}$ & $\begin{array}{c}\mathbf{0 . 1 2 4} \\
(0.042)\end{array}$ & $\begin{array}{c}\mathbf{0 . 1 3 8} \\
(0.043)\end{array}$ & $\begin{array}{c}-0.011 \\
(0.015)\end{array}$ & $\begin{array}{c}0.022 \\
(0.053)\end{array}$ & $\begin{array}{c}-0.001 \\
(0.042)\end{array}$ & $\begin{array}{l}-0.041 \\
(0.029)\end{array}$ & $\begin{array}{c}-0.038 \\
(0.081)\end{array}$ & $\begin{array}{c}-0.034 \\
(0.079)\end{array}$ \\
\hline Sample Size & 251,366 & 251,366 & 251,366 & 23,822 & 23,822 & 23,822 & 180,968 & 180,968 & 180,968 & 37,007 & 37,007 & 37,007 \\
\hline
\end{tabular}

All models also include age, age squared, years of education, and indicators for married, employed, urban, region and survey year. NHIS annual weights used. Marginal effects reported for all probit models. Standard errors in parentheses. Bold results are statisticaly significant at the $10 \%$ level. 
Table 3b. Immigrant Cohort and Assimilation Effects of BMI for Men by Race/Ethnic Origin

\begin{tabular}{|c|c|c|c|c|c|c|c|c|c|c|c|c|}
\hline & \multicolumn{3}{|c|}{ All Origins } & \multicolumn{3}{|c|}{ Hispanic } & \multicolumn{3}{|c|}{ White } & \multicolumn{3}{|c|}{ Black } \\
\hline & Ln BMI & Overweight & Obese & Ln BMI & Overweight & Obese & Ln BMI & Overweight & Obese & Ln BMI & Overweight & Obese \\
\hline \multicolumn{13}{|l|}{ Cohort Effects } \\
\hline \multicolumn{13}{|l|}{ Immigrated: } \\
\hline \multirow[t]{2}{*}{1980 or Before } & -0.040 & -0.146 & -0.089 & -0.042 & -0.165 & -0.111 & -0.029 & -0.136 & -0.105 & -0.012 & -0.076 & -0.048 \\
\hline & $(0.007)$ & $(0.025)$ & $(0.014)$ & $(0.013)$ & $(0.043)$ & $(0.029)$ & $(0.013)$ & $(0.051)$ & $(0.024)$ & $(0.021)$ & $(0.088)$ & $(0.074)$ \\
\hline 1981-85 & $\begin{array}{r}-0.051 \\
(005)\end{array}$ & $\mathbf{- 0 . 1 5 8}$ & $\begin{array}{r}-\mathbf{0 . 0 9 8} \\
\end{array}$ & $\begin{array}{c}-\mathbf{0 . 0 5 2} \\
0099\end{array}$ & $\begin{array}{r}-0.178 \\
\end{array}$ & $\mathbf{- 0 . 1 1 1}$ & $\begin{array}{r}-0.032 \\
\end{array}$ & $\mathbf{- 0 . 1 0 8}$ & $\begin{array}{c}-\mathbf{0 . 0 9 6} \\
\end{array}$ & $\begin{array}{r}-0.021 \\
-017\end{array}$ & -0.053 & $\begin{array}{r}-0.090 \\
(0.045)\end{array}$ \\
\hline \multirow[t]{2}{*}{$1986-90$} & -0.055 & -0.170 & -0.104 & -0.062 & -0.200 & -0.122 & -0.038 & -0.143 & -0.098 & -0.038 & -0.070 & -0.117 \\
\hline & $(0.003)$ & $(0.011)$ & $(0.005)$ & $(0.005)$ & $(0.019)$ & $(0.009)$ & $(0.005)$ & $(0.021)$ & $(0.011)$ & $(0.011)$ & $(0.044)$ & $(0.020)$ \\
\hline 1991-95 & $\begin{array}{l}-\mathbf{- 0 . 0 6 5} \\
(0.003)\end{array}$ & $\begin{array}{c}\mathbf{- 0 . 1 7 2} \\
(0.012)\end{array}$ & $\begin{array}{c}-\mathbf{0 . 1 0 3} \\
(0.006)\end{array}$ & $\begin{array}{c}-\mathbf{0 . 0 8 2} \\
(0.006)\end{array}$ & $\begin{array}{l}\mathbf{- 0 . 2 0 7} \\
(0.020)\end{array}$ & $\begin{array}{l}\mathbf{- 0 . 1 2 7} \\
(0.007)\end{array}$ & $\begin{array}{c}-\mathbf{0 . 0 3 8} \\
(0.006)\end{array}$ & $\begin{array}{c}\mathbf{- 0 . 1 2 7} \\
(0.023)\end{array}$ & $\begin{array}{c}-0.072 \\
(0.014)\end{array}$ & $\begin{array}{c}\mathbf{- 0 . 0 5 0} \\
(0.014)\end{array}$ & $\begin{array}{c}\mathbf{- 0 . 0 8 5} \\
(0.050)\end{array}$ & $\begin{array}{l}\mathbf{- 0 . 1 0 3} \\
(0.026)\end{array}$ \\
\hline \multicolumn{13}{|c|}{ Assimilation Effects } \\
\hline \multicolumn{13}{|c|}{$\overline{\text { Years Since Arrival: }}$} \\
\hline $5-9$ & $\begin{array}{c}-0.003 \\
(0.004)\end{array}$ & $\begin{array}{c}0.023 \\
(0.015)\end{array}$ & $\begin{array}{l}-0.006 \\
(0.014)\end{array}$ & $\begin{array}{c}\mathbf{- 0 . 0 1 1} \\
(0.007)\end{array}$ & $\begin{array}{c}0.011 \\
(0.024)\end{array}$ & $\begin{array}{c}-0.021 \\
(0.020)\end{array}$ & $\begin{array}{c}0.002 \\
(0.007)\end{array}$ & $\begin{array}{c}\mathbf{0 . 0 5 8} \\
(0.029)\end{array}$ & $\begin{array}{c}0.032 \\
(0.033)\end{array}$ & $\begin{array}{c}\mathbf{- 0 . 0 3 6} \\
(0.014)\end{array}$ & $\begin{array}{c}\mathbf{- 0 . 1 0 3} \\
(0.058)\end{array}$ & $\begin{array}{l}-0.070 \\
(0.043)\end{array}$ \\
\hline $10-14$ & $\begin{array}{c}0.001 \\
(0.006)\end{array}$ & $\begin{array}{c}\mathbf{0 . 0 3 8} \\
(0.022)\end{array}$ & $\begin{array}{c}0.003 \\
(0.021)\end{array}$ & $\begin{array}{c}-0.008 \\
(0.011)\end{array}$ & $\begin{array}{c}0.044 \\
(0.035)\end{array}$ & $\begin{array}{l}-0.008 \\
(0.031)\end{array}$ & $\begin{array}{c}0.002 \\
(0.012)\end{array}$ & $\begin{array}{c}0.064 \\
(0.043)\end{array}$ & $\begin{array}{c}0.056 \\
(0.051)\end{array}$ & $\begin{array}{c}-\mathbf{0 . 0 3 2} \\
(0.019)\end{array}$ & $\begin{array}{l}-0.013 \\
(0.079)\end{array}$ & $\begin{array}{l}-0.084 \\
(0.054)\end{array}$ \\
\hline $15+$ & $\begin{array}{c}\mathbf{0 . 0 1 8} \\
(0.007)\end{array}$ & $\begin{array}{c}\mathbf{0 . 0 8 5} \\
(0.024)\end{array}$ & $\begin{array}{c}\mathbf{0 . 0 5 3} \\
(0.027)\end{array}$ & $\begin{array}{c}0.006 \\
(0.013)\end{array}$ & $\begin{array}{c}\mathbf{0 . 0 7 2} \\
(0.042)\end{array}$ & $\begin{array}{c}0.027 \\
(0.038)\end{array}$ & $\begin{array}{c}0.021 \\
(0.013)\end{array}$ & $\begin{array}{c}\mathbf{0 . 1 0 7} \\
(0.046)\end{array}$ & $\begin{array}{c}\mathbf{0 . 1 3 0} \\
(0.065)\end{array}$ & $\begin{array}{c}\mathbf{- 0 . 0 4 0} \\
(0.022)\end{array}$ & $\begin{array}{l}-0.006 \\
(0.089)\end{array}$ & $\begin{array}{l}-0.105 \\
(0.052)\end{array}$ \\
\hline Sample Size & 228,768 & 228,768 & 228,768 & 21,781 & 21,781 & 21,781 & 172,548 & 172,548 & 172,548 & 25,931 & 25,931 & 25,931 \\
\hline
\end{tabular}

All models also include age, age squared, years of education, and indicators for married, employed, urban, region and survey year. NHIS annual weights used. Marginal effects reported for all probit models. Standard errors in parentheses. Bold results are statisticaly significant at the $10 \%$ level. 
Appendix Table 1. Variable Definitions

\begin{tabular}{ll}
\hline Variable Name & Definitions \\
\hline Poor Health & $=1$ if SRHS=4 (fair) or 5 (poor) \\
Health Conditions & $=1$ if 1 or more health conditions are reported \\
Activity Limitations & $=1$ if activity or work is limited \\
Poverty & kilograms/meters \\
BMI & $=1$ if BMI 25+ \\
Overweight & $=1$ if BMI 30+ \\
Obese & Immigrated to the U.S. in or before 1980 (see page 7 for more detail) \\
Immigrated 1980 or Before & Immigrated to the U.S. between 1981-1985 (see page 7 for more detail) \\
Immigrated 1981-85 & Immigrated to the U.S. between 1986-1990 (see page 7 for more detail) \\
Immigrated 1986-90 & Immigrated to the U.S. between 1991-1996 (see page 7 for more detail) \\
Immigrated 1991-96 & Arrived in the U.S. 0-4 years ago \\
$0-4$ Years Since Arrival & Arrived in the U.S. 5-9 years ago \\
5-9 Years Since Arrival & Arrived in the U.S. 10-14 years ago \\
10-14 Years Since Arrival & Arrived in the U.S. 15 or more years ago \\
15+ Years Since Arrival & continuous measure from 20-64 \\
Age & $=1$ if married \\
Married & continuous measure from 0-18 \\
Years of Education & $=1$ if worked in past 2 weeks \\
Working/Employed & $=1$ if reside in a MSA \\
Urban &
\end{tabular}


Appendix Table 2a. Actual Weight Regressions by Gender and Racial/Ethnic Origin

\begin{tabular}{|c|c|c|c|c|c|c|c|c|}
\hline \multicolumn{9}{|l|}{ Panel A: Women } \\
\hline & \multicolumn{2}{|c|}{ Hispanic } & \multicolumn{2}{|c|}{ White } & \multicolumn{2}{|c|}{ Black } & \multicolumn{2}{|c|}{ Other } \\
\hline & Nat & Imm & Nat & Imm & Nat & Imm & Nat & Imm \\
\hline Weight & $\begin{array}{c}\mathbf{1 . 4 9 2} \\
(0.146)\end{array}$ & $\begin{array}{c}\mathbf{0 . 9 6 7} \\
(0.120)\end{array}$ & $\begin{array}{c}\mathbf{1 . 1 8 3} \\
(0.049)\end{array}$ & $\begin{array}{c}0.430 \\
(0.442)\end{array}$ & $\begin{array}{c}1.232 \\
(0.055)\end{array}$ & $\begin{array}{c}\mathbf{0 . 7 4 0} \\
(0.311)\end{array}$ & $\begin{array}{c}0.278 \\
(0.475)\end{array}$ & $\begin{array}{c}\mathbf{0 . 6 1 5} \\
(0.299)\end{array}$ \\
\hline Weight Squared & $\begin{array}{l}-\mathbf{0 . 0 0 1} \\
(0.000)\end{array}$ & $\begin{array}{c}0.000 \\
(0.000)\end{array}$ & $\begin{array}{c}\mathbf{0 . 0 0 0} \\
(0.000)\end{array}$ & $\begin{array}{c}0.002 \\
(0.001)\end{array}$ & $\begin{array}{c}\mathbf{0 . 0 0 0} \\
(0.000)\end{array}$ & $\begin{array}{c}0.001 \\
(0.001)\end{array}$ & $\begin{array}{c}\mathbf{0 . 0 0 3} \\
(0.001)\end{array}$ & $\begin{array}{c}\mathbf{0 . 0 0 2} \\
(0.001)\end{array}$ \\
\hline Constant & $\begin{array}{c}\mathbf{- 4 1 . 5 4 8} \\
(12.521)\end{array}$ & $\begin{array}{c}4.621 \\
(10.362)\end{array}$ & $\begin{array}{l}-\mathbf{1 4 . 5 6 0} \\
(3.832)\end{array}$ & $\begin{array}{c}48.487 \\
(34.906)\end{array}$ & $\begin{array}{l}-19.751 \\
(4.754)\end{array}$ & $\begin{array}{c}19.100 \\
(24.237)\end{array}$ & $\begin{array}{c}48.506 \\
(38.190)\end{array}$ & $\begin{array}{c}19.949 \\
(21.037)\end{array}$ \\
\hline R-Squared & 0.908 & 0.922 & 0.944 & 0.910 & 0.919 & 0.934 & 0.839 & 0.932 \\
\hline Sample Size & 938 & 762 & 2,130 & 101 & 1,941 & 127 & 19 & 68 \\
\hline \multicolumn{9}{|l|}{ Panel B: Men } \\
\hline & \multicolumn{2}{|c|}{ Hispanic } & \multicolumn{2}{|c|}{ White } & \multicolumn{2}{|c|}{ Black } & \multicolumn{2}{|c|}{ Other } \\
\hline & Nat & Imm & Nat & Imm & Nat & Imm & Nat & Imm \\
\hline Weight & $\begin{array}{c}\mathbf{1 . 1 6 5} \\
(0.111)\end{array}$ & $\begin{array}{c}\mathbf{0 . 5 3 7} \\
(0.163)\end{array}$ & $\begin{array}{c}\mathbf{0 . 9 7 6} \\
(0.054)\end{array}$ & $\begin{array}{c}0.305 \\
(0.319)\end{array}$ & $\begin{array}{c}\mathbf{0 . 9 6 0} \\
(0.088)\end{array}$ & $\begin{array}{c}\mathbf{1 . 5 3 7} \\
(0.321)\end{array}$ & $\begin{array}{c}0.212 \\
(0.325)\end{array}$ & $\begin{array}{c}\mathbf{0 . 3 7 3} \\
(0.181)\end{array}$ \\
\hline Weight Squared & $\begin{array}{c}0.000 \\
(0.000)\end{array}$ & $\begin{array}{c}\mathbf{0 . 0 0 1} \\
(0.000)\end{array}$ & $\begin{array}{c}0.000 \\
(0.000)\end{array}$ & $\begin{array}{c}\mathbf{0 . 0 0 2} \\
(0.001)\end{array}$ & $\begin{array}{c}0.000 \\
(0.000)\end{array}$ & $\begin{array}{c}-\mathbf{0 . 0 0 2} \\
(0.001)\end{array}$ & $\begin{array}{c}\mathbf{0 . 0 0 2} \\
(0.001)\end{array}$ & $\begin{array}{c}\mathbf{0 . 0 0 2} \\
(0.000)\end{array}$ \\
\hline Constant & $\begin{array}{l}\mathbf{- 1 9 . 0 9 5} \\
(10.585)\end{array}$ & $\begin{array}{c}35.736 \\
(13.893)\end{array}$ & $\begin{array}{l}-0.942 \\
(5.612)\end{array}$ & $\begin{array}{c}\mathbf{6 0 . 6 5 2} \\
(30.247)\end{array}$ & $\begin{array}{l}-4.823 \\
(8.572)\end{array}$ & $\begin{array}{l}-43.987 \\
(26.774)\end{array}$ & $\begin{array}{c}\mathbf{6 3 . 8 3 2} \\
(26.670)\end{array}$ & $\begin{array}{c}\mathbf{5 3 . 1 1 4} \\
(16.922)\end{array}$ \\
\hline R-Squared & 0.950 & 0.926 & 0.952 & 0.954 & 0.939 & 0.894 & 0.971 & 0.962 \\
\hline Sample Size & 838 & 856 & 1,815 & 82 & 1,548 & 99 & 21 & 55 \\
\hline
\end{tabular}

Source: Nhanes.

Nhanes weights used. Standard errors in parentheses. Bold coefficients significant at the $10 \%$ level. While the "Other" category is not used separately in the analysis, it is a component of "All Origins". 
Appendix Table 2b. Actual Height Regressions by Gender and Racial/Ethnic Origin

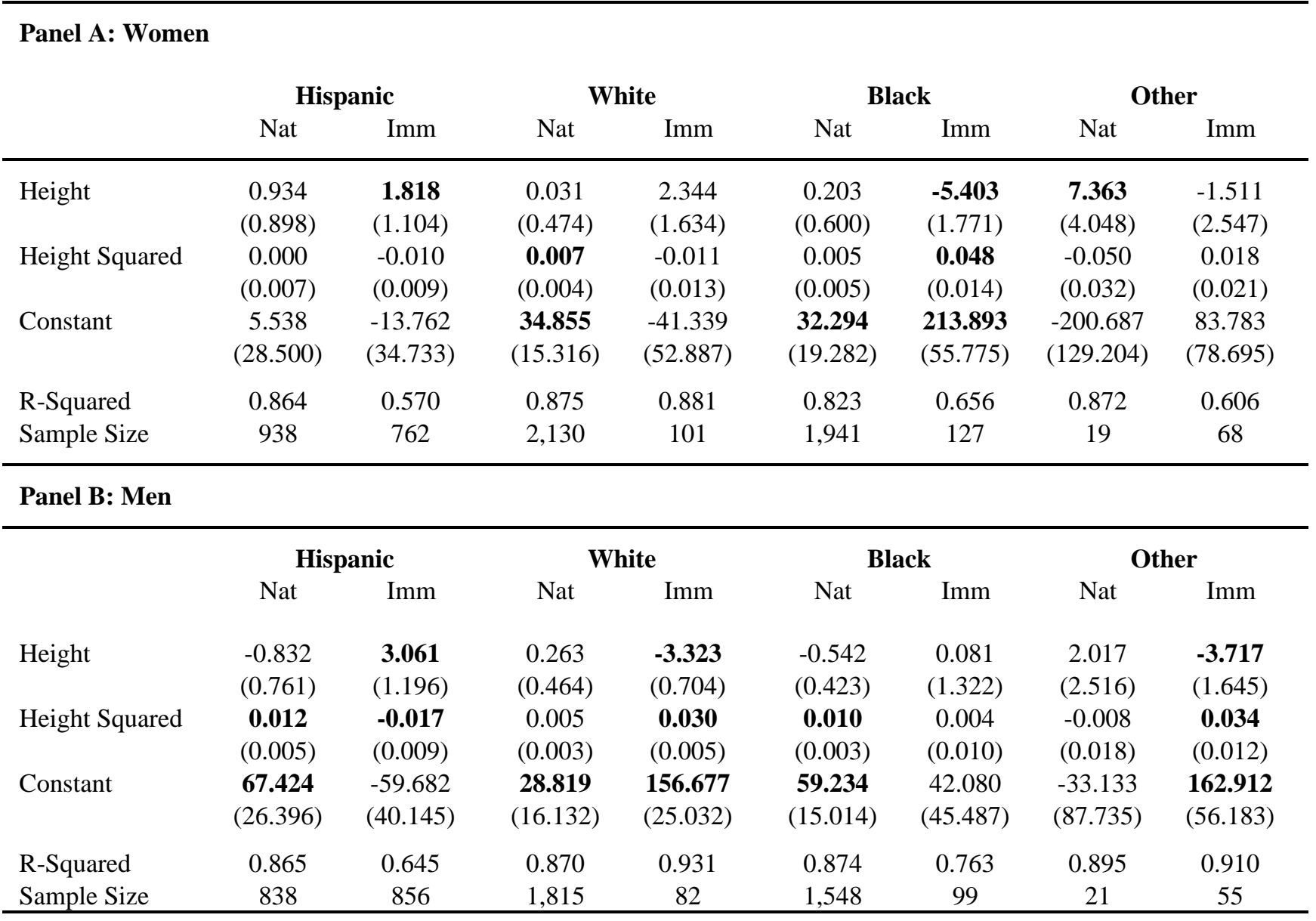

Source: Nhanes.

Nhanes weights used. Standard errors in parentheses. Bold coefficients significant at the $10 \%$ level. While the "Other" category is not used separately in the analysis, it is a component of "All Origins". 
Appendix Table 3a. BMI Regressions for Women by Race/Ethnic Origin - Remaining Parameter Estimates

\begin{tabular}{|c|c|c|c|c|c|c|c|c|c|c|c|c|}
\hline & \multicolumn{3}{|c|}{ All Origins } & \multicolumn{3}{|c|}{ Hispanic } & \multicolumn{3}{|c|}{ White } & \multicolumn{3}{|c|}{ Black } \\
\hline & Ln BMI & Overweight & Obese & Ln BMI & Overweight & Obese & Ln BMI & Overweight & Obese & Ln BMI & Overweight & Obese \\
\hline Age & $\begin{array}{c}\mathbf{0 . 0 1 2} \\
(0.000)\end{array}$ & $\begin{array}{c}\mathbf{0 . 0 2 3} \\
(0.001)\end{array}$ & $\begin{array}{c}\mathbf{0 . 0 1 7} \\
(0.000)\end{array}$ & $\begin{array}{c}\mathbf{0 . 0 1 4} \\
(0.001)\end{array}$ & $\begin{array}{c}\mathbf{0 . 0 2 7} \\
(0.002)\end{array}$ & $\begin{array}{c}\mathbf{0 . 0 2 3} \\
(0.002)\end{array}$ & $\begin{array}{c}\mathbf{0 . 0 1 1} \\
(0.000)\end{array}$ & $\begin{array}{c}\mathbf{0 . 0 2 0} \\
(0.001)\end{array}$ & $\begin{array}{c}\mathbf{0 . 0 1 5} \\
(0.001)\end{array}$ & $\begin{array}{c}\mathbf{0 . 0 1 4} \\
(0.001)\end{array}$ & $\begin{array}{c}\mathbf{0 . 0 2 4} \\
(0.002)\end{array}$ & $\begin{array}{c}\mathbf{0 . 0 2 3} \\
(0.002)\end{array}$ \\
\hline Age Squared & $\begin{array}{c}\mathbf{0 . 0 0 0} \\
(0.000)\end{array}$ & $\begin{array}{c}\mathbf{0 . 0 0 0} \\
(0.000)\end{array}$ & $\begin{array}{c}\mathbf{0 . 0 0 0} \\
(0.000)\end{array}$ & $\begin{array}{c}\mathbf{0 . 0 0 0} \\
(0.000)\end{array}$ & $\begin{array}{c}\mathbf{0 . 0 0 0} \\
(0.000)\end{array}$ & $\begin{array}{c}\mathbf{0 . 0 0 0} \\
(0.000)\end{array}$ & $\begin{array}{c}\mathbf{0 . 0 0 0} \\
(0.000)\end{array}$ & $\begin{array}{c}\mathbf{0 . 0 0 0} \\
(0.000)\end{array}$ & $\begin{array}{c}\mathbf{0 . 0 0 0} \\
(0.000)\end{array}$ & $\begin{array}{c}\mathbf{0 . 0 0 0} \\
(0.000)\end{array}$ & $\begin{array}{c}\mathbf{0 . 0 0 0} \\
(0.000)\end{array}$ & $\begin{array}{c}\mathbf{0 . 0 0 0} \\
(0.000)\end{array}$ \\
\hline Married & $\begin{array}{c}\mathbf{- 0 . 0 3 0} \\
(0.001)\end{array}$ & $\begin{array}{c}\mathbf{- 0 . 0 5 4} \\
(0.002)\end{array}$ & $\begin{array}{c}\mathbf{- 0 . 0 5 5} \\
(0.002)\end{array}$ & $\begin{array}{c}-0.003 \\
(0.003)\end{array}$ & $\begin{array}{c}-0.001 \\
(0.008)\end{array}$ & $\begin{array}{c}\mathbf{- 0 . 0 2 3} \\
(0.007)\end{array}$ & $\begin{array}{c}\mathbf{- 0 . 0 1 6} \\
(0.001)\end{array}$ & $\begin{array}{c}\mathbf{- 0 . 0 2 4} \\
(0.003)\end{array}$ & $\begin{array}{c}\mathbf{- 0 . 0 3 6} \\
(0.002)\end{array}$ & $\begin{array}{c}\mathbf{- 0 . 0 1 3} \\
(0.003)\end{array}$ & $\begin{array}{c}\mathbf{- 0 . 0 1 3} \\
(0.006)\end{array}$ & $\begin{array}{c}\mathbf{- 0 . 0 2 5} \\
(0.006)\end{array}$ \\
\hline Yrs of Education & $\begin{array}{c}\mathbf{- 0 . 0 1 2} \\
(0.000)\end{array}$ & $\begin{array}{c}\mathbf{- 0 . 0 2 9} \\
(0.000)\end{array}$ & $\begin{array}{c}\mathbf{- 0 . 0 1 7} \\
(0.000)\end{array}$ & $\begin{array}{c}\mathbf{- 0 . 0 0 8} \\
(0.000)\end{array}$ & $\begin{array}{c}\mathbf{- 0 . 0 2 2} \\
(0.001)\end{array}$ & $\begin{array}{c}\mathbf{- 0 . 0 1 4} \\
(0.001)\end{array}$ & $\begin{array}{c}\mathbf{- 0 . 0 1 0} \\
(0.000)\end{array}$ & $\begin{array}{c}\mathbf{- 0 . 0 2 5} \\
(0.001)\end{array}$ & $\begin{array}{c}\mathbf{- 0 . 0 1 5} \\
(0.000)\end{array}$ & $\begin{array}{c}\mathbf{- 0 . 0 1 0} \\
(0.001)\end{array}$ & $\begin{array}{c}\mathbf{- 0 . 0 1 8} \\
(0.001)\end{array}$ & $\begin{array}{c}\mathbf{- 0 . 0 1 9} \\
(0.001)\end{array}$ \\
\hline Employed & $\begin{array}{c}\mathbf{- 0 . 0 2 1} \\
(0.001)\end{array}$ & $\begin{array}{c}\mathbf{- 0 . 0 4 1} \\
(0.002)\end{array}$ & $\begin{array}{c}\mathbf{- 0 . 0 3 6} \\
(0.002)\end{array}$ & $\begin{array}{c}\mathbf{- 0 . 0 3 1} \\
(0.003)\end{array}$ & $\begin{array}{c}\mathbf{- 0 . 0 6 3} \\
(0.008)\end{array}$ & $\begin{array}{c}\mathbf{- 0 . 0 6 7} \\
(0.006)\end{array}$ & $\begin{array}{c}\mathbf{- 0 . 0 1 6} \\
(0.001)\end{array}$ & $\begin{array}{c}\mathbf{- 0 . 0 3 4} \\
(0.003)\end{array}$ & $\begin{array}{c}\mathbf{- 0 . 0 2 8} \\
(0.002)\end{array}$ & $\begin{array}{c}\mathbf{- 0 . 0 1 8} \\
(0.003)\end{array}$ & $\begin{array}{c}\mathbf{- 0 . 0 1 2} \\
(0.006)\end{array}$ & $\begin{array}{r}\mathbf{- 0 . 0 3 9} \\
(0.006)\end{array}$ \\
\hline Urban Residence & $\begin{array}{c}-\mathbf{0 . 0 1 2} \\
(0.001)\end{array}$ & $\begin{array}{c}-\mathbf{0 . 0 2 6} \\
(0.003)\end{array}$ & $\begin{array}{c}-\mathbf{0 . 0 1 9} \\
(0.002)\end{array}$ & $\begin{array}{c}-0.009 \\
(0.006)\end{array}$ & $\begin{array}{c}-0.001 \\
(0.014)\end{array}$ & $\begin{array}{l}-0.017 \\
(0.012)\end{array}$ & $\begin{array}{c}-\mathbf{- 0 . 0 2 0} \\
(0.001)\end{array}$ & $\begin{array}{c}-\mathbf{0 . 0 4 5} \\
(0.003)\end{array}$ & $\begin{array}{c}-\mathbf{0 . 0 2 9} \\
(0.002)\end{array}$ & $\begin{array}{c}-\mathbf{0 . 0 2 6} \\
(0.004)\end{array}$ & $\begin{array}{c}-\mathbf{0 . 0 5 4} \\
(0.009)\end{array}$ & $\begin{array}{c}\mathbf{- 0 . 0 5 0} \\
(0.009)\end{array}$ \\
\hline Midwest & $\begin{array}{c}\mathbf{0 . 0 1 2} \\
(0.001)\end{array}$ & $\begin{array}{c}\mathbf{0 . 0 2 4} \\
(0.003)\end{array}$ & $\begin{array}{c}\mathbf{0 . 0 1 9} \\
(0.003)\end{array}$ & $\begin{array}{c}0.002 \\
(0.006)\end{array}$ & $\begin{array}{c}0.024 \\
(0.017)\end{array}$ & $\begin{array}{c}-0.020 \\
(0.014)\end{array}$ & $\begin{array}{c}\mathbf{0 . 0 1 5} \\
(0.001)\end{array}$ & $\begin{array}{c}\mathbf{0 . 0 2 8} \\
(0.004)\end{array}$ & $\begin{array}{c}\mathbf{0 . 0 2 2} \\
(0.003)\end{array}$ & $\begin{array}{c}0.001 \\
(0.004)\end{array}$ & $\begin{array}{c}-0.002 \\
(0.009)\end{array}$ & $\begin{array}{c}0.005 \\
(0.009)\end{array}$ \\
\hline West & $\begin{array}{c}\mathbf{0 . 0 1 2} \\
(0.001)\end{array}$ & $\begin{array}{c}\mathbf{0 . 0 2 5} \\
(0.003)\end{array}$ & $\begin{array}{c}\mathbf{0 . 0 2 1} \\
(0.002)\end{array}$ & $\begin{array}{c}\mathbf{0 . 0 1 8} \\
(0.004)\end{array}$ & $\begin{array}{c}\mathbf{0 . 0 5 2} \\
(0.011)\end{array}$ & $\begin{array}{c}\mathbf{0 . 0 1 8} \\
(0.010)\end{array}$ & $\begin{array}{c}-0.002 \\
(0.001)\end{array}$ & $\begin{array}{c}-0.004 \\
(0.004)\end{array}$ & $\begin{array}{c}0.001 \\
(0.003)\end{array}$ & $\begin{array}{c}0.004 \\
(0.004)\end{array}$ & $\begin{array}{c}-0.003 \\
(0.008)\end{array}$ & $\begin{array}{c}\mathbf{0 . 0 1 6} \\
(0.008)\end{array}$ \\
\hline South & $\begin{array}{c}\mathbf{- 0 . 0 0 6} \\
(0.001)\end{array}$ & $\begin{array}{c}\mathbf{- 0 . 0 2 2} \\
(0.003)\end{array}$ & $\begin{array}{c}\mathbf{- 0 . 0 0 6} \\
(0.003)\end{array}$ & $\begin{array}{c}0.005 \\
(0.004)\end{array}$ & $\begin{array}{c}\mathbf{0 . 0 2 0} \\
(0.011)\end{array}$ & $\begin{array}{c}0.000 \\
(0.009)\end{array}$ & $\begin{array}{c}\mathbf{- 0 . 0 0 6} \\
(0.001)\end{array}$ & $\begin{array}{c}\mathbf{- 0 . 0 2 0} \\
(0.004)\end{array}$ & $\begin{array}{c}-0.004 \\
(0.003)\end{array}$ & $\begin{array}{c}\mathbf{- 0 . 0 1 6} \\
(0.005)\end{array}$ & $\begin{array}{c}\mathbf{- 0 . 0 4 8} \\
(0.012)\end{array}$ & $\begin{array}{c}\mathbf{- 0 . 0 3 1} \\
(0.011)\end{array}$ \\
\hline 1990 & $\begin{array}{c}\mathbf{0 . 0 0 3} \\
(0.002)\end{array}$ & $\begin{array}{c}\mathbf{0 . 0 1 4} \\
(0.004)\end{array}$ & $\begin{array}{c}0.004 \\
(0.003)\end{array}$ & $\begin{array}{c}0.009 \\
(0.006)\end{array}$ & $\begin{array}{c}\mathbf{0 . 0 3 2} \\
(0.016)\end{array}$ & $\begin{array}{c}0.004 \\
(0.014)\end{array}$ & $\begin{array}{c}0.001 \\
(0.002)\end{array}$ & $\begin{array}{c}\mathbf{0 . 0 1 0} \\
(0.005)\end{array}$ & $\begin{array}{c}0.002 \\
(0.003)\end{array}$ & $\begin{array}{c}0.007 \\
(0.004)\end{array}$ & $\begin{array}{c}\mathbf{0 . 0 2 2} \\
(0.010)\end{array}$ & $\begin{array}{c}0.010 \\
(0.010)\end{array}$ \\
\hline 1991 & $\begin{array}{c}\mathbf{0 . 0 1 3} \\
(0.002)\end{array}$ & $\begin{array}{c}\mathbf{0 . 0 3 3} \\
(0.004)\end{array}$ & $\begin{array}{c}\mathbf{0 . 0 2 3} \\
(0.003)\end{array}$ & $\begin{array}{c}\mathbf{0 . 0 2 0} \\
(0.005)\end{array}$ & $\begin{array}{c}\mathbf{0 . 0 6 2} \\
(0.014)\end{array}$ & $\begin{array}{c}\mathbf{0 . 0 2 4} \\
(0.013)\end{array}$ & $\begin{array}{c}\mathbf{0 . 0 0 9} \\
(0.002)\end{array}$ & $\begin{array}{c}\mathbf{0 . 0 2 5} \\
(0.005)\end{array}$ & $\begin{array}{c}\mathbf{0 . 0 1 8} \\
(0.004)\end{array}$ & $\begin{array}{c}\mathbf{0 . 0 1 6} \\
(0.004)\end{array}$ & $\begin{array}{c}\mathbf{0 . 0 3 4} \\
(0.010)\end{array}$ & $\begin{array}{c}\mathbf{0 . 0 3 8} \\
(0.011)\end{array}$ \\
\hline 1992 & $\begin{array}{c}\mathbf{0 . 0 1 8} \\
(0.002)\end{array}$ & $\begin{array}{c}\mathbf{0 . 0 4 2} \\
(0.004)\end{array}$ & $\begin{array}{c}\mathbf{0 . 0 2 7} \\
(0.003)\end{array}$ & $\begin{array}{c}\mathbf{0 . 0 1 1} \\
(0.006)\end{array}$ & $\begin{array}{c}\mathbf{0 . 0 3 7} \\
(0.016)\end{array}$ & $\begin{array}{c}0.006 \\
(0.014)\end{array}$ & $\begin{array}{c}\mathbf{0 . 0 1 7} \\
(0.002)\end{array}$ & $\begin{array}{c}\mathbf{0 . 0 4 4} \\
(0.005)\end{array}$ & $\begin{array}{c}\mathbf{0 . 0 2 5} \\
(0.004)\end{array}$ & $\begin{array}{c}\mathbf{0 . 0 2 6} \\
(0.005)\end{array}$ & $\begin{array}{c}\mathbf{0 . 0 3 9} \\
(0.010)\end{array}$ & $\begin{array}{c}\mathbf{0 . 0 6 2} \\
(0.011)\end{array}$ \\
\hline 1993 & $\begin{array}{c}\mathbf{0 . 0 2 5} \\
(0.002)\end{array}$ & $\begin{array}{c}\mathbf{0 . 0 6 3} \\
(0.004)\end{array}$ & $\begin{array}{c}\mathbf{0 . 0 4 2} \\
(0.004)\end{array}$ & $\begin{array}{c}\mathbf{0 . 0 3 2} \\
(0.006)\end{array}$ & $\begin{array}{c}\mathbf{0 . 0 8 1} \\
(0.016)\end{array}$ & $\begin{array}{c}\mathbf{0 . 0 3 4} \\
(0.015)\end{array}$ & $\begin{array}{c}\mathbf{0 . 0 2 0} \\
(0.002)\end{array}$ & $\begin{array}{c}\mathbf{0 . 0 5 4} \\
(0.005)\end{array}$ & $\begin{array}{c}\mathbf{0 . 0 3 3} \\
(0.004)\end{array}$ & $\begin{array}{c}\mathbf{0 . 0 4 0} \\
(0.005)\end{array}$ & $\begin{array}{c}\mathbf{0 . 0 7 7} \\
(0.010)\end{array}$ & $\begin{array}{c}\mathbf{0 . 0 8 8} \\
(0.011)\end{array}$ \\
\hline 1994 & $\begin{array}{c}\mathbf{0 . 0 2 7} \\
(0.002)\end{array}$ & $\begin{array}{c}\mathbf{0 . 0 6 5} \\
(0.004)\end{array}$ & $\begin{array}{c}\mathbf{0 . 0 4 5} \\
(0.004)\end{array}$ & $\begin{array}{c}\mathbf{0 . 0 2 8} \\
(0.006)\end{array}$ & $\begin{array}{c}\mathbf{0 . 0 6 6} \\
(0.016)\end{array}$ & $\begin{array}{c}\mathbf{0 . 0 4 0} \\
(0.015)\end{array}$ & $\begin{array}{c}\mathbf{0 . 0 2 5} \\
(0.002)\end{array}$ & $\begin{array}{c}\mathbf{0 . 0 6 4} \\
(0.005)\end{array}$ & $\begin{array}{c}\mathbf{0 . 0 4 0} \\
(0.004)\end{array}$ & $\begin{array}{c}\mathbf{0 . 0 3 4} \\
(0.005)\end{array}$ & $\begin{array}{c}\mathbf{0 . 0 5 8} \\
(0.011)\end{array}$ & $\begin{array}{c}\mathbf{0 . 0 7 3} \\
(0.011)\end{array}$ \\
\hline 1995 & $\begin{array}{c}\mathbf{0 . 0 3 3} \\
(0.002)\end{array}$ & $\begin{array}{c}\mathbf{0 . 0 7 8} \\
(0.004)\end{array}$ & $\begin{array}{c}\mathbf{0 . 0 5 2} \\
(0.004)\end{array}$ & $\begin{array}{c}\mathbf{0 . 0 3 0} \\
(0.006)\end{array}$ & $\begin{array}{c}\mathbf{0 . 0 7 3} \\
(0.014)\end{array}$ & $\begin{array}{c}\mathbf{0 . 0 5 2} \\
(0.014)\end{array}$ & $\begin{array}{c}\mathbf{0 . 0 3 2} \\
(0.002)\end{array}$ & $\begin{array}{c}\mathbf{0 . 0 7 6} \\
(0.005)\end{array}$ & $\begin{array}{c}\mathbf{0 . 0 4 7} \\
(0.004)\end{array}$ & $\begin{array}{c}\mathbf{0 . 0 3 6} \\
(0.005)\end{array}$ & $\begin{array}{c}\mathbf{0 . 0 6 7} \\
(0.011)\end{array}$ & $\begin{array}{c}\mathbf{0 . 0 7 2} \\
(0.012)\end{array}$ \\
\hline 1996 & $\begin{array}{c}\mathbf{0 . 0 3 8} \\
(0.002)\end{array}$ & $\begin{array}{c}\mathbf{0 . 0 8 4} \\
(0.005)\end{array}$ & $\begin{array}{c}\mathbf{0 . 0 6 0} \\
(0.004)\end{array}$ & $\begin{array}{c}\mathbf{0 . 0 4 0} \\
(0.006)\end{array}$ & $\begin{array}{c}\mathbf{0 . 0 8 8} \\
(0.015)\end{array}$ & $\begin{array}{c}\mathbf{0 . 0 5 6} \\
(0.015)\end{array}$ & $\begin{array}{c}\mathbf{0 . 0 3 4} \\
(0.002)\end{array}$ & $\begin{array}{c}\mathbf{0 . 0 7 9} \\
(0.006)\end{array}$ & $\begin{array}{c}\mathbf{0 . 0 5 2} \\
(0.005)\end{array}$ & $\begin{array}{c}\mathbf{0 . 0 4 5} \\
(0.005)\end{array}$ & $\begin{array}{c}\mathbf{0 . 0 7 6} \\
(0.012)\end{array}$ & $\begin{array}{c}\mathbf{0 . 0 9 9} \\
(0.013)\end{array}$ \\
\hline Constant & $\begin{array}{c}3.095 \\
(0.005)\end{array}$ & & & $\begin{array}{c}3.065 \\
(0.018)\end{array}$ & & & $\begin{array}{c}3.076 \\
(0.006)\end{array}$ & & & $\begin{array}{c}3.098 \\
(0.016)\end{array}$ & & \\
\hline Sample Size & 251,366 & 251,366 & 251,366 & 23,822 & 23,822 & 23,822 & 180,968 & 180,968 & 180,968 & 37,007 & 37,007 & 37,007 \\
\hline
\end{tabular}

Based on results presented in Table 3a. 
Appendix Table 3b. BMI Regressions for Men by Race/Ethnic Origin - Remaining Parameter Estimates

\begin{tabular}{|c|c|c|c|c|c|c|c|c|c|c|c|c|}
\hline & \multicolumn{3}{|c|}{ All Origins } & \multicolumn{3}{|c|}{ Hispanic } & \multicolumn{3}{|c|}{ White } & \multicolumn{3}{|c|}{ Black } \\
\hline & Ln BMI & Overweight & Obese & Ln BMI & Overweight & Obese & Ln BMI & Overweight & Obese & Ln BMI & Overweight & Obese \\
\hline Age & $\begin{array}{c}\mathbf{0 . 0 1 0} \\
(0.000)\end{array}$ & $\begin{array}{c}\mathbf{0 . 0 2 5} \\
(0.001)\end{array}$ & $\begin{array}{c}\mathbf{0 . 0 1 4} \\
(0.001)\end{array}$ & $\begin{array}{c}\mathbf{0 . 0 0 9} \\
(0.001)\end{array}$ & $\begin{array}{c}\mathbf{0 . 0 2 4} \\
(0.002)\end{array}$ & $\begin{array}{c}\mathbf{0 . 0 1 5} \\
(0.002)\end{array}$ & $\begin{array}{c}\mathbf{0 . 0 1 1} \\
(0.000)\end{array}$ & $\begin{array}{c}\mathbf{0 . 0 2 8} \\
(0.001)\end{array}$ & $\begin{array}{c}\mathbf{0 . 0 1 6} \\
(0.001)\end{array}$ & $\begin{array}{c}\mathbf{0 . 0 0 7} \\
(0.001)\end{array}$ & $\begin{array}{c}\mathbf{0 . 0 1 6} \\
(0.002)\end{array}$ & $\begin{array}{c}\mathbf{0 . 0 1 0} \\
(0.002)\end{array}$ \\
\hline Age Squared & $\begin{array}{c}\mathbf{0 . 0 0 0} \\
(0.000)\end{array}$ & $\begin{array}{c}\mathbf{0 . 0 0 0} \\
(0.000)\end{array}$ & $\begin{array}{c}\mathbf{0 . 0 0 0} \\
(0.000)\end{array}$ & $\begin{array}{c}\mathbf{0 . 0 0 0} \\
(0.000)\end{array}$ & $\begin{array}{c}\mathbf{0 . 0 0 0} \\
(0.000)\end{array}$ & $\begin{array}{c}\mathbf{0 . 0 0 0} \\
(0.000)\end{array}$ & $\begin{array}{c}\mathbf{0 . 0 0 0} \\
(0.000)\end{array}$ & $\begin{array}{c}\mathbf{0 . 0 0 0} \\
(0.000)\end{array}$ & $\begin{array}{c}\mathbf{0 . 0 0 0} \\
(0.000)\end{array}$ & $\begin{array}{c}\mathbf{0 . 0 0 0} \\
(0.000)\end{array}$ & $\begin{array}{c}\mathbf{0 . 0 0 0} \\
(0.000)\end{array}$ & $\begin{array}{c}\mathbf{0 . 0 0 0} \\
(0.000)\end{array}$ \\
\hline Married & $\begin{array}{c}\mathbf{0 . 0 2 9} \\
(0.001)\end{array}$ & $\begin{array}{c}\mathbf{0 . 0 9 8} \\
(0.003)\end{array}$ & $\begin{array}{c}\mathbf{0 . 0 3 0} \\
(0.002)\end{array}$ & $\begin{array}{c}\mathbf{0 . 0 3 6} \\
(0.003)\end{array}$ & $\begin{array}{c}\mathbf{0 . 1 1 6} \\
(0.009)\end{array}$ & $\begin{array}{c}\mathbf{0 . 0 5 1} \\
(0.006)\end{array}$ & $\begin{array}{c}\mathbf{0 . 0 2 6} \\
(0.001)\end{array}$ & $\begin{array}{c}\mathbf{0 . 0 9 2} \\
(0.003)\end{array}$ & $\begin{array}{c}\mathbf{0 . 0 2 7} \\
(0.002)\end{array}$ & $\begin{array}{c}\mathbf{0 . 0 3 8} \\
(0.003)\end{array}$ & $\begin{array}{c}\mathbf{0 . 1 1 1} \\
(0.008)\end{array}$ & $\begin{array}{c}\mathbf{0 . 0 4 7} \\
(0.006)\end{array}$ \\
\hline Yrs of Education & $\begin{array}{c}\mathbf{- 0 . 0 0 3} \\
(0.000)\end{array}$ & $\begin{array}{c}\mathbf{- 0 . 0 0 9} \\
(0.000)\end{array}$ & $\begin{array}{c}\mathbf{- 0 . 0 0 9} \\
(0.000)\end{array}$ & $\begin{array}{c}\mathbf{- 0 . 0 0 2} \\
(0.000)\end{array}$ & $\begin{array}{c}\mathbf{- 0 . 0 0 4} \\
(0.001)\end{array}$ & $\begin{array}{c}\mathbf{- 0 . 0 0 4} \\
(0.001)\end{array}$ & $\begin{array}{c}\mathbf{- 0 . 0 0 3} \\
(0.000)\end{array}$ & $\begin{array}{c}\mathbf{- 0 . 0 0 8} \\
(0.001)\end{array}$ & $\begin{array}{c}\mathbf{- 0 . 0 0 9} \\
(0.000)\end{array}$ & $\begin{array}{c}\mathbf{0 . 0 0 1} \\
(0.000)\end{array}$ & $\begin{array}{c}\mathbf{0 . 0 0 5} \\
(0.001)\end{array}$ & $\begin{array}{c}-0.002 \\
(0.001)\end{array}$ \\
\hline Employed & $\begin{array}{c}\mathbf{0 . 0 0 6} \\
(0.001)\end{array}$ & $\begin{array}{c}\mathbf{0 . 0 3 4} \\
(0.003)\end{array}$ & $\begin{array}{c}\mathbf{- 0 . 0 1 0} \\
(0.002)\end{array}$ & $\begin{array}{c}0.004 \\
(0.003)\end{array}$ & $\begin{array}{c}\mathbf{0 . 0 3 7} \\
(0.010)\end{array}$ & $\begin{array}{l}-0.009 \\
(0.008)\end{array}$ & $\begin{array}{c}\mathbf{0 . 0 0 3} \\
(0.001)\end{array}$ & $\begin{array}{c}\mathbf{0 . 0 2 4} \\
(0.004)\end{array}$ & $\begin{array}{c}\mathbf{- 0 . 0 1 6} \\
(0.003)\end{array}$ & $\begin{array}{c}\mathbf{0 . 0 2 0} \\
(0.003)\end{array}$ & $\begin{array}{c}\mathbf{0 . 0 5 2} \\
(0.008)\end{array}$ & $\begin{array}{c}\mathbf{0 . 0 1 7} \\
(0.006)\end{array}$ \\
\hline Urban Residence & $\begin{array}{c}-\mathbf{0 . 0 0 5} \\
(0.001)\end{array}$ & $\begin{array}{c}-\mathbf{0 . 0 1 2} \\
(0.003)\end{array}$ & $\begin{array}{c}-\mathbf{0 . 0 1 3} \\
(0.002)\end{array}$ & $\begin{array}{c}-0.003 \\
(0.004)\end{array}$ & $\begin{array}{c}-0.013 \\
(0.014)\end{array}$ & $\begin{array}{l}-0.014 \\
(0.010)\end{array}$ & $\begin{array}{c}-\mathbf{0 . 0 0 6} \\
(0.001)\end{array}$ & $\begin{array}{c}-\mathbf{0 . 0 1 4} \\
(0.003)\end{array}$ & $\begin{array}{l}-\mathbf{0 . 0 1 5} \\
(0.002)\end{array}$ & $\begin{array}{c}-\mathbf{0 . 0 1 2} \\
(0.004)\end{array}$ & $\begin{array}{c}-\mathbf{0 . 0 2 5} \\
(0.011)\end{array}$ & $\begin{array}{c}\mathbf{- 0 . 0 2 1} \\
(0.009)\end{array}$ \\
\hline Midwest & $\begin{array}{c}0.001 \\
(0.001)\end{array}$ & $\begin{array}{l}-0.005 \\
(0.003)\end{array}$ & $\begin{array}{c}\mathbf{0 . 0 0 9} \\
(0.003)\end{array}$ & $\begin{array}{c}0.005 \\
(0.005)\end{array}$ & $\begin{array}{c}0.002 \\
(0.017)\end{array}$ & $\begin{array}{c}0.001 \\
(0.013)\end{array}$ & $\begin{array}{c}0.001 \\
(0.001)\end{array}$ & $\begin{array}{c}-0.005 \\
(0.004)\end{array}$ & $\begin{array}{c}\mathbf{0 . 0 1 0} \\
(0.003)\end{array}$ & $\begin{array}{c}-0.003 \\
(0.004)\end{array}$ & $\begin{array}{c}-0.018 \\
(0.012)\end{array}$ & $\begin{array}{c}0.010 \\
(0.009)\end{array}$ \\
\hline West & $\begin{array}{c}0.000 \\
(0.001)\end{array}$ & $\begin{array}{c}\mathbf{- 0 . 0 1 0} \\
(0.003)\end{array}$ & $\begin{array}{c}\mathbf{0 . 0 1 2} \\
(0.002)\end{array}$ & $\begin{array}{c}\mathbf{0 . 0 1 5} \\
(0.004)\end{array}$ & $\begin{array}{c}\mathbf{0 . 0 3 1} \\
(0.012)\end{array}$ & $\begin{array}{c}\mathbf{0 . 0 2 5} \\
(0.010)\end{array}$ & $\begin{array}{c}\mathbf{- 0 . 0 0 4} \\
(0.001)\end{array}$ & $\begin{array}{c}\mathbf{- 0 . 0 1 8} \\
(0.004)\end{array}$ & $\begin{array}{c}\mathbf{0 . 0 0 5} \\
(0.003)\end{array}$ & $\begin{array}{c}0.001 \\
(0.003)\end{array}$ & $\begin{array}{c}-0.012 \\
(0.010)\end{array}$ & $\begin{array}{c}\mathbf{0 . 0 2 2} \\
(0.008)\end{array}$ \\
\hline South & $\begin{array}{c}\mathbf{- 0 . 0 1 1} \\
(0.001)\end{array}$ & $\begin{array}{c}\mathbf{- 0 . 0 4 4} \\
(0.004)\end{array}$ & $\begin{array}{c}\mathbf{- 0 . 0 1 2} \\
(0.003)\end{array}$ & $\begin{array}{c}\mathbf{0 . 0 0 7} \\
(0.004)\end{array}$ & $\begin{array}{c}0.016 \\
(0.012)\end{array}$ & $\begin{array}{c}0.001 \\
(0.009)\end{array}$ & $\begin{array}{c}\mathbf{- 0 . 0 1 6} \\
(0.001)\end{array}$ & $\begin{array}{c}\mathbf{- 0 . 0 5 7} \\
(0.004)\end{array}$ & $\begin{array}{c}\mathbf{- 0 . 0 1 8} \\
(0.003)\end{array}$ & $\begin{array}{l}-0.006 \\
(0.005)\end{array}$ & $\begin{array}{c}\mathbf{- 0 . 0 2 6} \\
(0.014)\end{array}$ & $\begin{array}{c}-0.014 \\
(0.011)\end{array}$ \\
\hline 1990 & $\begin{array}{c}\mathbf{0 . 0 0 3} \\
(0.001)\end{array}$ & $\begin{array}{c}\mathbf{0 . 0 0 9} \\
(0.004)\end{array}$ & $\begin{array}{c}0.001 \\
(0.003)\end{array}$ & $\begin{array}{c}0.001 \\
(0.005)\end{array}$ & $\begin{array}{c}-0.001 \\
(0.016)\end{array}$ & $\begin{array}{l}-0.002 \\
(0.012)\end{array}$ & $\begin{array}{c}0.002 \\
(0.001)\end{array}$ & $\begin{array}{c}0.007 \\
(0.005)\end{array}$ & $\begin{array}{c}0.000 \\
(0.004)\end{array}$ & $\begin{array}{c}\mathbf{0 . 0 0 9} \\
(0.004)\end{array}$ & $\begin{array}{c}\mathbf{0 . 0 2 2} \\
(0.013)\end{array}$ & $\begin{array}{c}\mathbf{0 . 0 2 3} \\
(0.011)\end{array}$ \\
\hline 1991 & $\begin{array}{c}\mathbf{0 . 0 0 8} \\
(0.001)\end{array}$ & $\begin{array}{c}\mathbf{0 . 0 2 2} \\
(0.004)\end{array}$ & $\begin{array}{c}\mathbf{0 . 0 1 4} \\
(0.003)\end{array}$ & $\begin{array}{c}\mathbf{0 . 0 0 9} \\
(0.004)\end{array}$ & $\begin{array}{c}\mathbf{0 . 0 3 0} \\
(0.014)\end{array}$ & $\begin{array}{c}0.017 \\
(0.012)\end{array}$ & $\begin{array}{c}\mathbf{0 . 0 0 6} \\
(0.001)\end{array}$ & $\begin{array}{c}\mathbf{0 . 0 1 8} \\
(0.005)\end{array}$ & $\begin{array}{c}\mathbf{0 . 0 1 1} \\
(0.004)\end{array}$ & $\begin{array}{c}\mathbf{0 . 0 0 9} \\
(0.004)\end{array}$ & $\begin{array}{c}0.020 \\
(0.013)\end{array}$ & $\begin{array}{c}0.016 \\
(0.011)\end{array}$ \\
\hline 1992 & $\begin{array}{c}\mathbf{0 . 0 1 1} \\
(0.001)\end{array}$ & $\begin{array}{c}\mathbf{0 . 0 2 5} \\
(0.004)\end{array}$ & $\begin{array}{c}\mathbf{0 . 0 2 2} \\
(0.003)\end{array}$ & $\begin{array}{c}0.007 \\
(0.005)\end{array}$ & $\begin{array}{c}0.010 \\
(0.016)\end{array}$ & $\begin{array}{c}0.006 \\
(0.013)\end{array}$ & $\begin{array}{c}\mathbf{0 . 0 1 2} \\
(0.001)\end{array}$ & $\begin{array}{c}\mathbf{0 . 0 2 6} \\
(0.005)\end{array}$ & $\begin{array}{c}\mathbf{0 . 0 2 3} \\
(0.004)\end{array}$ & $\begin{array}{c}\mathbf{0 . 0 1 9} \\
(0.004)\end{array}$ & $\begin{array}{c}\mathbf{0 . 0 3 7} \\
(0.013)\end{array}$ & $\begin{array}{c}\mathbf{0 . 0 4 5} \\
(0.012)\end{array}$ \\
\hline 1993 & $\begin{array}{c}\mathbf{0 . 0 1 7} \\
(0.001)\end{array}$ & $\begin{array}{c}\mathbf{0 . 0 4 2} \\
(0.004)\end{array}$ & $\begin{array}{c}\mathbf{0 . 0 3 6} \\
(0.004)\end{array}$ & $\begin{array}{c}\mathbf{0 . 0 1 5} \\
(0.005)\end{array}$ & $\begin{array}{c}\mathbf{0 . 0 2 8} \\
(0.017)\end{array}$ & $\begin{array}{c}\mathbf{0 . 0 2 7} \\
(0.014)\end{array}$ & $\begin{array}{c}\mathbf{0 . 0 1 6} \\
(0.001)\end{array}$ & $\begin{array}{c}\mathbf{0 . 0 3 9} \\
(0.005)\end{array}$ & $\begin{array}{c}\mathbf{0 . 0 3 5} \\
(0.004)\end{array}$ & $\begin{array}{c}\mathbf{0 . 0 2 4} \\
(0.005)\end{array}$ & $\begin{array}{c}\mathbf{0 . 0 5 6} \\
(0.013)\end{array}$ & $\begin{array}{c}\mathbf{0 . 0 5 8} \\
(0.012)\end{array}$ \\
\hline 1994 & $\begin{array}{c}\mathbf{0 . 0 2 0} \\
(0.001)\end{array}$ & $\begin{array}{c}\mathbf{0 . 0 5 2} \\
(0.004)\end{array}$ & $\begin{array}{c}\mathbf{0 . 0 4 0} \\
(0.004)\end{array}$ & $\begin{array}{c}\mathbf{0 . 0 2 4} \\
(0.005)\end{array}$ & $\begin{array}{c}\mathbf{0 . 0 6 8} \\
(0.016)\end{array}$ & $\begin{array}{c}\mathbf{0 . 0 3 7} \\
(0.014)\end{array}$ & $\begin{array}{c}\mathbf{0 . 0 1 9} \\
(0.001)\end{array}$ & $\begin{array}{c}\mathbf{0 . 0 4 8} \\
(0.005)\end{array}$ & $\begin{array}{c}\mathbf{0 . 0 3 7} \\
(0.004)\end{array}$ & $\begin{array}{c}\mathbf{0 . 0 2 9} \\
(0.004)\end{array}$ & $\begin{array}{c}\mathbf{0 . 0 5 3} \\
(0.013)\end{array}$ & $\begin{array}{c}\mathbf{0 . 0 7 3} \\
(0.012)\end{array}$ \\
\hline 1995 & $\begin{array}{c}\mathbf{0 . 0 2 4} \\
(0.001)\end{array}$ & $\begin{array}{c}\mathbf{0 . 0 6 1} \\
(0.004)\end{array}$ & $\begin{array}{c}\mathbf{0 . 0 4 8} \\
(0.004)\end{array}$ & $\begin{array}{c}\mathbf{0 . 0 2 8} \\
(0.005)\end{array}$ & $\begin{array}{c}\mathbf{0 . 0 6 6} \\
(0.015)\end{array}$ & $\begin{array}{c}\mathbf{0 . 0 5 0} \\
(0.013)\end{array}$ & $\begin{array}{c}\mathbf{0 . 0 2 2} \\
(0.002)\end{array}$ & $\begin{array}{c}\mathbf{0 . 0 5 7} \\
(0.005)\end{array}$ & $\begin{array}{c}\mathbf{0 . 0 4 5} \\
(0.004)\end{array}$ & $\begin{array}{c}\mathbf{0 . 0 3 3} \\
(0.005)\end{array}$ & $\begin{array}{c}\mathbf{0 . 0 6 6} \\
(0.013)\end{array}$ & $\begin{array}{c}\mathbf{0 . 0 7 1} \\
(0.012)\end{array}$ \\
\hline 1996 & $\begin{array}{c}\mathbf{0 . 0 3 0} \\
(0.002)\end{array}$ & $\begin{array}{c}\mathbf{0 . 0 8 0} \\
(0.005)\end{array}$ & $\begin{array}{c}\mathbf{0 . 0 6 0} \\
(0.004)\end{array}$ & $\begin{array}{c}\mathbf{0 . 0 3 0} \\
(0.005)\end{array}$ & $\begin{array}{c}\mathbf{0 . 0 6 8} \\
(0.016)\end{array}$ & $\begin{array}{c}\mathbf{0 . 0 4 7} \\
(0.014)\end{array}$ & $\begin{array}{c}\mathbf{0 . 0 2 8} \\
(0.002)\end{array}$ & $\begin{array}{c}\mathbf{0 . 0 7 7} \\
(0.006)\end{array}$ & $\begin{array}{c}\mathbf{0 . 0 5 5} \\
(0.005)\end{array}$ & $\begin{array}{c}\mathbf{0 . 0 3 7} \\
(0.005)\end{array}$ & $\begin{array}{c}\mathbf{0 . 0 8 8} \\
(0.015)\end{array}$ & $\begin{array}{c}\mathbf{0 . 0 9 9} \\
(0.014)\end{array}$ \\
\hline Constant & $\begin{array}{c}3.052 \\
(0.004)\end{array}$ & & & $\begin{array}{c}3.066 \\
(0.015)\end{array}$ & & & $\begin{array}{c}3.032 \\
(0.005)\end{array}$ & & & $\begin{array}{c}3.051 \\
(0.015)\end{array}$ & & \\
\hline Sample Size & 228,768 & 228,768 & 228,768 & 21,781 & 21,781 & 21,781 & 172,548 & 172,548 & 172,548 & 25,931 & 25,931 & 25,931 \\
\hline
\end{tabular}

Based on results presented in Table $3 \mathrm{~b}$. 
Appendix Table 4. Immigrant Cohort and Assimilation Effects of Poverty by Gender and Race/Ethnic Origin

\begin{tabular}{|c|c|c|c|c|c|c|c|c|}
\hline & \multicolumn{4}{|c|}{ Women } & \multicolumn{4}{|c|}{ Men } \\
\hline & All Origins & Hispanic & White & Black & All Origins & Hispanic & White & Black \\
\hline \multicolumn{9}{|l|}{ Cohort Effects } \\
\hline \multicolumn{9}{|l|}{$\overline{\text { Immigrated: }}$} \\
\hline 1980 or Before & $\begin{array}{c}\mathbf{0 . 0 3 5} \\
(0.014)\end{array}$ & $\begin{array}{c}0.023 \\
(0.039)\end{array}$ & $\begin{array}{c}0.004 \\
(0.017)\end{array}$ & $\begin{array}{c}-0.057 \\
(0.071)\end{array}$ & $\begin{array}{c}\mathbf{0 . 0 5 3} \\
(0.014)\end{array}$ & $\begin{array}{c}0.032 \\
(0.035)\end{array}$ & $\begin{array}{c}\mathbf{0 . 0 3 0} \\
(0.023)\end{array}$ & $\begin{array}{c}0.118 \\
(0.096)\end{array}$ \\
\hline 1981-85 & $\begin{array}{c}\mathbf{0 . 0 4 8} \\
(0.012)\end{array}$ & $\begin{array}{c}0.045 \\
(0.031)\end{array}$ & $\begin{array}{c}\mathbf{0 . 0 3 2} \\
(0.019)\end{array}$ & $\begin{array}{c}\mathbf{- 0 . 0 9 5} \\
(0.043)\end{array}$ & $\begin{array}{c}\mathbf{0 . 0 6 4} \\
(0.012)\end{array}$ & $\begin{array}{c}\mathbf{0 . 0 7 6} \\
(0.029)\end{array}$ & $\begin{array}{c}\mathbf{0 . 0 4 3} \\
(0.019)\end{array}$ & $\begin{array}{c}0.076 \\
(0.067)\end{array}$ \\
\hline $1986-90$ & $\begin{array}{c}\mathbf{0 . 0 8 3} \\
(0.008)\end{array}$ & $\begin{array}{c}\mathbf{0 . 1 0 6} \\
(0.019)\end{array}$ & $\begin{array}{c}\mathbf{0 . 0 6 5} \\
(0.013)\end{array}$ & $\begin{array}{c}-\mathbf{0 . 0 9 2} \\
(0.028)\end{array}$ & $\begin{array}{c}\mathbf{0 . 1 0 2} \\
(0.008)\end{array}$ & $\begin{array}{c}\mathbf{0 . 1 7 5} \\
(0.019)\end{array}$ & $\begin{array}{c}\mathbf{0 . 0 7 7} \\
(0.013)\end{array}$ & $\begin{array}{c}\mathbf{0 . 0 5 6} \\
(0.038)\end{array}$ \\
\hline 1991-95 & $\begin{array}{c}\mathbf{0 . 0 7 9} \\
(0.008)\end{array}$ & $\begin{array}{c}\mathbf{0 . 1 0 0} \\
(0.019)\end{array}$ & $\begin{array}{c}\mathbf{0 . 1 0 6} \\
(0.017)\end{array}$ & $\begin{array}{l}-0.018 \\
(0.042)\end{array}$ & $\begin{array}{c}\mathbf{0 . 1 1 9} \\
(0.010)\end{array}$ & $\begin{array}{c}\mathbf{0 . 2 2 3} \\
(0.023)\end{array}$ & $\begin{array}{c}\mathbf{0 . 1 1 3} \\
(0.018)\end{array}$ & $\begin{array}{c}0.062 \\
(0.043)\end{array}$ \\
\hline \multicolumn{9}{|c|}{ Assimilation Effects } \\
\hline $5-9$ & $\begin{array}{c}-0.008 \\
(0.005)\end{array}$ & $\begin{array}{l}-0.004 \\
(0.021)\end{array}$ & $\begin{array}{l}-0.005 \\
(0.008)\end{array}$ & $\begin{array}{c}\mathbf{0 . 1 4 0} \\
(0.069)\end{array}$ & $\begin{array}{c}-0.004 \\
(0.005)\end{array}$ & $\begin{array}{l}-0.005 \\
(0.018)\end{array}$ & $\begin{array}{c}-0.002 \\
(0.007)\end{array}$ & $\begin{array}{c}-0.026 \\
(0.035)\end{array}$ \\
\hline $10-14$ & $\begin{array}{c}-0.002 \\
(0.009)\end{array}$ & $\begin{array}{c}0.024 \\
(0.035)\end{array}$ & $\begin{array}{c}0.011 \\
(0.017)\end{array}$ & $\begin{array}{c}0.075 \\
(0.089)\end{array}$ & $\begin{array}{c}0.002 \\
(0.007)\end{array}$ & $\begin{array}{c}0.035 \\
(0.031)\end{array}$ & $\begin{array}{c}-0.002 \\
(0.011)\end{array}$ & $\begin{array}{l}-0.043 \\
(0.042)\end{array}$ \\
\hline $15+$ & $\begin{array}{c}\mathbf{- 0 . 0 2 4} \\
(0.007)\end{array}$ & $\begin{array}{l}-0.018 \\
(0.038)\end{array}$ & $\begin{array}{c}-0.010 \\
(0.012)\end{array}$ & $\begin{array}{l}-0.031 \\
(0.080)\end{array}$ & $\begin{array}{c}-\mathbf{0 . 0 1 5} \\
(0.006)\end{array}$ & $\begin{array}{c}0.004 \\
(0.034)\end{array}$ & $\begin{array}{l}-0.015 \\
(0.009)\end{array}$ & $\begin{array}{c}-0.067 \\
(0.038)\end{array}$ \\
\hline Sample Size & 238,270 & 21,845 & 174,891 & 32,568 & 215,620 & 19,969 & 164,695 & 22,943 \\
\hline
\end{tabular}

All models also include age, age squared, years of education, and indicators for married, employed, urban, region and survey year. NHIS annual weights used. Marginal effects reported for all probit models. Standard errors in parentheses. Bold results are statisticaly significant at the $10 \%$ level. Sample size varies due to non-reporting with respect to the dependent variable. 
Appendix Table 5a. Immigrant Cohort and Assimilation Effects of Unadjusted BMI for Women by Race/Ethnic Origin

\begin{tabular}{|c|c|c|c|c|c|c|c|c|c|c|c|c|}
\hline & \multicolumn{3}{|c|}{ All Origins } & \multicolumn{3}{|c|}{ Hispanic } & \multicolumn{3}{|c|}{ White } & \multicolumn{3}{|c|}{ Black } \\
\hline & Ln BMI & Overweight & Obese & Ln BMI & Overweight & Obese & Ln BMI & Overweight & Obese & Ln BMI & Overweight & Obese \\
\hline \multicolumn{13}{|l|}{ Cohort Effects } \\
\hline \multicolumn{13}{|l|}{$\overline{\text { Immigrated: }}$} \\
\hline \multirow[t]{2}{*}{1980 or Before } & -0.045 & -0.126 & -0.083 & -0.055 & -0.199 & -0.150 & -0.016 & -0.039 & -0.037 & 0.001 & -0.038 & -0.014 \\
\hline & $(0.008)$ & $(0.021)$ & $(0.011)$ & $(0.015)$ & $(0.042)$ & $(0.027)$ & $(0.016)$ & $(0.049)$ & $(0.030)$ & $(0.028)$ & $(0.080)$ & $(0.078)$ \\
\hline \multirow[t]{2}{*}{ 1981-85 } & -0.053 & -0.133 & -0.091 & -0.061 & -0.192 & -0.129 & -0.029 & -0.051 & -0.059 & -0.031 & -0.083 & -0.090 \\
\hline & $(0.006)$ & $(0.016)$ & $(0.007)$ & $(0.011)$ & $(0.029)$ & $(0.014)$ & $(0.012)$ & $(0.035)$ & $(0.018)$ & $(0.021)$ & $(0.061)$ & $(0.048)$ \\
\hline \multirow[t]{2}{*}{$1986-90$} & -0.043 & -0.097 & -0.079 & -0.049 & -0.140 & -0.110 & -0.011 & -0.026 & -0.044 & -0.049 & -0.066 & -0.128 \\
\hline & $(0.003)$ & $(0.010)$ & $(0.005)$ & $(0.006)$ & $(0.018)$ & $(0.010)$ & $(0.007)$ & $(0.020)$ & $(0.012)$ & $(0.011)$ & $(0.036)$ & $(0.024)$ \\
\hline \multirow[t]{2}{*}{ 1991-95 } & -0.057 & -0.113 & -0.077 & -0.057 & -0.125 & -0.097 & -0.016 & -0.025 & -0.024 & -0.071 & -0.118 & -0.128 \\
\hline & $(0.004)$ & $(0.010)$ & $(0.005)$ & $(0.006)$ & $(0.018)$ & $(0.009)$ & $(0.007)$ & $(0.021)$ & $(0.013)$ & $(0.016)$ & $(0.044)$ & $(0.032)$ \\
\hline \multicolumn{13}{|c|}{ Assimilation Effects } \\
\hline \multicolumn{13}{|c|}{ Years Since Arrival: } \\
\hline \multirow[t]{2}{*}{$5-9$} & 0.018 & 0.074 & 0.035 & 0.021 & 0.099 & 0.061 & 0.001 & 0.016 & 0.008 & 0.005 & 0.031 & 0.002 \\
\hline & $(0.005)$ & $(0.016)$ & $(0.014)$ & $(0.008)$ & $(0.025)$ & $(0.023)$ & $(0.010)$ & $(0.031)$ & $(0.024)$ & $(0.017)$ & $(0.049)$ & $(0.051)$ \\
\hline \multirow[t]{2}{*}{$10-14$} & 0.018 & 0.089 & 0.050 & 0.028 & 0.149 & 0.105 & 0.005 & 0.018 & 0.000 & -0.023 & -0.015 & -0.029 \\
\hline & $(0.007)$ & $(0.023)$ & $(0.021)$ & $(0.013)$ & $(0.037)$ & $(0.038)$ & $(0.015)$ & $(0.047)$ & $(0.035)$ & $(0.025)$ & $(0.071)$ & (0.069) \\
\hline \multirow[t]{2}{*}{$15^{+}$} & 0.024 & 0.097 & 0.059 & 0.035 & 0.163 & 0.122 & -0.003 & -0.002 & -0.003 & -0.044 & -0.049 & -0.096 \\
\hline & $(0.008)$ & $(0.026)$ & $(0.024)$ & $(0.015)$ & $(0.043)$ & $(0.041)$ & $(0.017)$ & $(0.051)$ & $(0.038)$ & $(0.029)$ & $(0.082)$ & $(0.063)$ \\
\hline Sample Size & 251,366 & 251,366 & 251,366 & 23,822 & 23,822 & 23,822 & 180,968 & 180,968 & 180,968 & 37,007 & 37,007 & 37,007 \\
\hline
\end{tabular}

All models also include age, age squared, years of education, and indicators for married, employed, urban, region and survey year. NHIS annual weights used. Marginal effects reported for all probit models. Standard errors in parentheses. Bold results are statisticaly significant at the $10 \%$ level. 
Appendix Table 5b. Immigrant Cohort and Assimilation Effects of Unadjusted BMI for Men by Race/Ethnic Origin

\begin{tabular}{|c|c|c|c|c|c|c|c|c|c|c|c|c|}
\hline & \multicolumn{3}{|c|}{ All Origins } & \multicolumn{3}{|c|}{ Hispanic } & \multicolumn{3}{|c|}{ White } & \multicolumn{3}{|c|}{ Black } \\
\hline & Ln BMI & Overweight & Obese & Ln BMI & Overweight & Obese & Ln BMI & Overweight & Obese & Ln BMI & Overweight & Obese \\
\hline \multicolumn{13}{|l|}{$\underline{\text { Cohort Effects }}$} \\
\hline \multicolumn{13}{|l|}{$\overline{\text { Immigrated: }}$} \\
\hline 1980 or Before & $\begin{array}{c}\mathbf{- 0 . 0 3 8} \\
(0.007)\end{array}$ & $\begin{array}{c}-\mathbf{0 . 1 4 6} \\
(0.025)\end{array}$ & $\begin{array}{c}\mathbf{- 0 . 0 5 3} \\
(0.016)\end{array}$ & $\begin{array}{c}\mathbf{- 0 . 0 3 2} \\
(0.012)\end{array}$ & $\begin{array}{c}\mathbf{- 0 . 1 4 6} \\
(0.043)\end{array}$ & $\begin{array}{c}\mathbf{- 0 . 0 8 2} \\
(0.029)\end{array}$ & $\begin{array}{c}\mathbf{- 0 . 0 3 1} \\
(0.013)\end{array}$ & $\begin{array}{c}\mathbf{- 0 . 1 4 0} \\
(0.051)\end{array}$ & $\begin{array}{c}-0.052 \\
(0.032)\end{array}$ & $\begin{array}{c}-0.005 \\
(0.022)\end{array}$ & $\begin{array}{c}-0.061 \\
(0.087)\end{array}$ & $\begin{array}{c}0.121 \\
(0.107)\end{array}$ \\
\hline 1981-85 & $\begin{array}{c}\mathbf{- 0 . 0 4 7} \\
(0.005)\end{array}$ & $\begin{array}{c}-\mathbf{0 . 1 5 1} \\
(0.019)\end{array}$ & $\begin{array}{c}\mathbf{- 0 . 0 6 7} \\
(0.011)\end{array}$ & $\begin{array}{c}\mathbf{- 0 . 0 3 8} \\
(0.009)\end{array}$ & $\begin{array}{c}\mathbf{- 0 . 1 4 4} \\
(0.032)\end{array}$ & $\begin{array}{c}-\mathbf{- 0 . 0 8 3} \\
(0.018)\end{array}$ & $\begin{array}{c}\mathbf{- 0 . 0 3 6} \\
(0.010)\end{array}$ & $\begin{array}{c}\mathbf{- 0 . 1 2 8} \\
(0.039)\end{array}$ & $\begin{array}{c}-\mathbf{0 . 0 6 6} \\
(0.022)\end{array}$ & $\begin{array}{l}-0.010 \\
(0.017)\end{array}$ & $\begin{array}{c}-0.024 \\
(0.067)\end{array}$ & $\begin{array}{c}0.059 \\
(0.076)\end{array}$ \\
\hline 1986-90 & $\begin{array}{c}-\mathbf{- 0 . 0 5 0} \\
(0.003)\end{array}$ & $\begin{array}{c}\mathbf{- 0 . 1 4 6} \\
(0.011)\end{array}$ & $\begin{array}{c}\mathbf{- 0 . 0 8 3} \\
(0.005)\end{array}$ & $\begin{array}{c}\mathbf{- 0 . 0 4 6} \\
(0.005)\end{array}$ & $\begin{array}{c}\mathbf{- 0 . 1 5 0} \\
(0.019)\end{array}$ & $\begin{array}{c}\mathbf{- 0 . 0 9 9} \\
(0.010)\end{array}$ & $\begin{array}{c}\mathbf{- 0 . 0 3 9} \\
(0.005)\end{array}$ & $\begin{array}{c}-\mathbf{- 0 . 1 3 3} \\
(0.021)\end{array}$ & $\begin{array}{c}\mathbf{- 0 . 0 8 4} \\
(0.010)\end{array}$ & $\begin{array}{c}-\mathbf{0 . 0 3 1} \\
(0.012)\end{array}$ & $\begin{array}{l}-0.047 \\
(0.043)\end{array}$ & $\begin{array}{c}\mathbf{- 0 . 0 5 8} \\
(0.029)\end{array}$ \\
\hline 1991-95 & $\begin{array}{c}\mathbf{- 0 . 0 6 1} \\
(0.003)\end{array}$ & $\begin{array}{c}\mathbf{- 0 . 1 5 7} \\
(0.012)\end{array}$ & $\begin{array}{c}\mathbf{- 0 . 0 8 1} \\
(0.006)\end{array}$ & $\begin{array}{c}\mathbf{- 0 . 0 6 6} \\
(0.006)\end{array}$ & $\begin{array}{c}\mathbf{- 0 . 1 5 6} \\
(0.020)\end{array}$ & $\begin{array}{c}\mathbf{- 0 . 1 0 5} \\
(0.008)\end{array}$ & $\begin{array}{c}\mathbf{- 0 . 0 3 9} \\
(0.006)\end{array}$ & $\begin{array}{c}\mathbf{- 0 . 1 2 8} \\
(0.023)\end{array}$ & $\begin{array}{c}\mathbf{- 0 . 0 6 1} \\
(0.013)\end{array}$ & $\begin{array}{c}\mathbf{- 0 . 0 4 3} \\
(0.014)\end{array}$ & $\begin{array}{c}-0.046 \\
(0.049)\end{array}$ & $\begin{array}{r}-\mathbf{0 . 0 6 0} \\
(0.030)\end{array}$ \\
\hline \multicolumn{13}{|c|}{$\frac{\text { Assimilation Effects }}{\text { Years Since Arrival: }}$} \\
\hline $5-9$ & $\begin{array}{l}-0.001 \\
(0.004)\end{array}$ & $\begin{array}{c}0.020 \\
(0.015)\end{array}$ & $\begin{array}{l}-0.015 \\
(0.012)\end{array}$ & $\begin{array}{l}-0.011 \\
(0.007)\end{array}$ & $\begin{array}{c}0.006 \\
(0.024)\end{array}$ & $\begin{array}{l}-0.017 \\
(0.019)\end{array}$ & $\begin{array}{c}0.003 \\
(0.007)\end{array}$ & $\begin{array}{c}\mathbf{0 . 0 7 1} \\
(0.029)\end{array}$ & $\begin{array}{c}0.011 \\
(0.029)\end{array}$ & $\begin{array}{c}-\mathbf{- 0 . 0 4 1} \\
(0.015)\end{array}$ & $\begin{array}{c}\mathbf{- 0 . 1 4 3} \\
(0.058)\end{array}$ & $\begin{array}{c}\mathbf{- 0 . 1 1 9} \\
(0.026)\end{array}$ \\
\hline $10-14$ & $\begin{array}{c}0.004 \\
(0.006)\end{array}$ & $\begin{array}{c}\mathbf{0 . 0 5 3} \\
(0.021)\end{array}$ & $\begin{array}{c}-0.013 \\
(0.018)\end{array}$ & $\begin{array}{c}-0.006 \\
(0.011)\end{array}$ & $\begin{array}{c}\mathbf{0 . 0 6 3} \\
(0.034)\end{array}$ & $\begin{array}{c}-0.004 \\
(0.029)\end{array}$ & $\begin{array}{c}0.006 \\
(0.012)\end{array}$ & $\begin{array}{c}\mathbf{0 . 0 7 9} \\
(0.042)\end{array}$ & $\begin{array}{c}0.002 \\
(0.040)\end{array}$ & $\begin{array}{c}\mathbf{- 0 . 0 3 8} \\
(0.020)\end{array}$ & $\begin{array}{c}-0.051 \\
(0.078)\end{array}$ & $\begin{array}{c}\mathbf{- 0 . 1 4 3} \\
(0.023)\end{array}$ \\
\hline $15+$ & $\begin{array}{c}\mathbf{0 . 0 1 8} \\
(0.007)\end{array}$ & $\begin{array}{c}\mathbf{0 . 0 9 3} \\
(0.023)\end{array}$ & $\begin{array}{c}0.012 \\
(0.022)\end{array}$ & $\begin{array}{c}0.007 \\
(0.013)\end{array}$ & $\begin{array}{c}\mathbf{0 . 0 9 0} \\
(0.041)\end{array}$ & $\begin{array}{c}0.026 \\
(0.036)\end{array}$ & $\begin{array}{c}0.019 \\
(0.014)\end{array}$ & $\begin{array}{c}\mathbf{0 . 1 1 0} \\
(0.046)\end{array}$ & $\begin{array}{c}0.025 \\
(0.049)\end{array}$ & $\begin{array}{c}-\mathbf{0 . 0 4 5} \\
(0.023)\end{array}$ & $\begin{array}{c}-0.020 \\
(0.088)\end{array}$ & $\begin{array}{c}\mathbf{- 0 . 1 5 2} \\
(0.024)\end{array}$ \\
\hline Sample Size & 228,768 & 228,768 & 228,768 & 21,781 & 21,781 & 21,781 & 172,548 & 172,548 & 172,548 & 25,931 & 25,931 & 25,931 \\
\hline
\end{tabular}

All models also include age, age squared, years of education, and indicators for married, employed, urban, region and survey year. NHIS annual weights used. Marginal effects reported for all probit models. Standard errors in parentheses. Bold results are statisticaly significant at the $10 \%$ level. 
Appendix Table 6a. Immigrant Cohort and Assimilation Effects of BMI Excluding Immigrants who Arrived Before Age 15 for Women by Race/Ethnic Origin

\begin{tabular}{|c|c|c|c|c|c|c|c|c|c|c|c|c|}
\hline & \multicolumn{6}{|c|}{ Specification 1} & \multicolumn{6}{|c|}{ Specification 2} \\
\hline & Ln BMI & $\begin{array}{l}\text { All Origins } \\
\text { Overweight }\end{array}$ & Obese & Ln BMI & $\begin{array}{c}\text { Hispanic } \\
\text { Overweight }\end{array}$ & Obese & Ln BMI & $\begin{array}{l}\text { All Origins } \\
\text { Overweight }\end{array}$ & Obese & Ln BMI & $\begin{array}{c}\text { Hispanic } \\
\text { Overweight }\end{array}$ & Obese \\
\hline \multicolumn{13}{|l|}{$\underline{\text { Cohort Effects }}$} \\
\hline \multicolumn{13}{|l|}{$\overline{\text { Immigrated: }}$} \\
\hline 1980 or Before & $\begin{array}{c}\mathbf{- 0 . 0 2 3} \\
(0.009)\end{array}$ & $\begin{array}{c}\mathbf{- 0 . 0 8 7} \\
(0.026)\end{array}$ & $\begin{array}{c}\mathbf{- 0 . 0 9 1} \\
(0.014)\end{array}$ & $\begin{array}{l}\mathbf{- 0 . 0 3 5} \\
(0.016)\end{array}$ & $\begin{array}{c}\mathbf{- 0 . 1 0 8} \\
(0.049)\end{array}$ & $\begin{array}{c}\mathbf{- 0 . 1 6 6} \\
(0.029)\end{array}$ & $\begin{array}{c}\mathbf{- 0 . 0 2 2} \\
(0.009)\end{array}$ & $\begin{array}{c}\mathbf{- 0 . 0 8 6} \\
(0.026)\end{array}$ & $\begin{array}{c}\mathbf{- 0 . 0 8 9} \\
(0.013)\end{array}$ & $\begin{array}{l}-0.027 \\
(0.017)\end{array}$ & $\begin{array}{c}\mathbf{- 0 . 0 8 9} \\
(0.051)\end{array}$ & $\begin{array}{c}\mathbf{- 0 . 1 4 1} \\
(0.025)\end{array}$ \\
\hline 1981-85 & $\begin{array}{l}-\mathbf{0 . 0 3 3} \\
(0.006)\end{array}$ & $\begin{array}{l}-\mathbf{0 . 0 9 6} \\
(0.018)\end{array}$ & $\begin{array}{c}-\mathbf{0 . 0 9 6} \\
(0.009)\end{array}$ & $\begin{array}{c}\mathbf{- 0 . 0 4 2} \\
(0.011)\end{array}$ & $\begin{array}{c}-\mathbf{0 . 1 2 6} \\
(0.034)\end{array}$ & $\begin{array}{l}-\mathbf{0 . 1 5 0} \\
(0.019)\end{array}$ & $\begin{array}{c}-\mathbf{0 . 0 3 3} \\
(0.006)\end{array}$ & $\begin{array}{l}-\mathbf{0 . 0 9 5} \\
(0.018)\end{array}$ & $\begin{array}{l}\mathbf{- 0 . 0 9 6} \\
(0.009)\end{array}$ & $\begin{array}{l}\mathbf{- 0 . 0 3 7} \\
(0.012)\end{array}$ & $\begin{array}{l}\mathbf{- 0 . 1 1 4} \\
(0.035)\end{array}$ & $\begin{array}{c}\mathbf{- 0 . 1 4 1} \\
(0.020)\end{array}$ \\
\hline 1986-90 & $\begin{array}{c}-\mathbf{0 . 0 2 4} \\
(0.003)\end{array}$ & $\begin{array}{l}-\mathbf{0 . 0 5 6} \\
(0.011)\end{array}$ & $\begin{array}{l}-\mathbf{0 . 0 8 5} \\
(0.006)\end{array}$ & $\begin{array}{c}-\mathbf{0 . 0 3 2} \\
(0.006)\end{array}$ & $\begin{array}{l}-\mathbf{- 0 . 0 6 8} \\
(0.019)\end{array}$ & $\begin{array}{c}-\mathbf{- 0 . 1 3 1} \\
(0.012)\end{array}$ & $\begin{array}{c}\mathbf{- 0 . 0 2 4} \\
(0.003)\end{array}$ & $\begin{array}{l}-\mathbf{- 0 . 0 5 6} \\
(0.011)\end{array}$ & $\begin{array}{l}-\mathbf{- 0 . 0 8 5} \\
(0.006)\end{array}$ & $\begin{array}{l}-\mathbf{- 0 . 0 3 0} \\
(0.006)\end{array}$ & $\begin{array}{l}-\mathbf{- 0 . 0 6 5} \\
(0.019)\end{array}$ & $\begin{array}{l}\mathbf{- 0 . 1 2 4} \\
(0.013)\end{array}$ \\
\hline 1991-95 & $\begin{array}{l}\mathbf{- 0 . 0 4 0} \\
(0.004)\end{array}$ & $\begin{array}{c}\mathbf{- 0 . 0 9 1} \\
(0.011)\end{array}$ & $\begin{array}{l}\mathbf{- 0 . 0 8 7} \\
(0.006)\end{array}$ & $\begin{array}{c}\mathbf{- 0 . 0 4 2} \\
(0.006)\end{array}$ & $\begin{array}{c}-\mathbf{0 . 0 7 3} \\
(0.019)\end{array}$ & $\begin{array}{c}\mathbf{- 0 . 1 1 7} \\
(0.012)\end{array}$ & $\begin{array}{c}\mathbf{- 0 . 0 4 1} \\
(0.004)\end{array}$ & $\begin{array}{c}\mathbf{- 0 . 0 9 1} \\
(0.011)\end{array}$ & $\begin{array}{l}-\mathbf{0 . 0 8 7} \\
(0.006)\end{array}$ & $\begin{array}{l}\mathbf{- 0 . 0 4 4} \\
(0.006)\end{array}$ & $\begin{array}{l}-\mathbf{0 . 0 7 7} \\
(0.019)\end{array}$ & $\begin{array}{l}\mathbf{- 0 . 1 1 2} \\
(0.012)\end{array}$ \\
\hline \multicolumn{13}{|c|}{$\frac{\text { Assimilation Effects }}{\text { Years Since Arrival: }}$} \\
\hline $5-9$ & $\begin{array}{c}\mathbf{0 . 0 1 6} \\
(0.005)\end{array}$ & $\begin{array}{c}\mathbf{0 . 0 6 8} \\
(0.016)\end{array}$ & $\begin{array}{c}\mathbf{0 . 0 4 0} \\
(0.015)\end{array}$ & $\begin{array}{c}\mathbf{0 . 0 1 6} \\
(0.008)\end{array}$ & $\begin{array}{c}\mathbf{0 . 0 8 8} \\
(0.024)\end{array}$ & $\begin{array}{c}\mathbf{0 . 0 6 4} \\
(0.025)\end{array}$ & $\begin{array}{c}\mathbf{0 . 0 1 6} \\
(0.005)\end{array}$ & $\begin{array}{c}\mathbf{0 . 0 6 8} \\
(0.016)\end{array}$ & $\begin{array}{c}\mathbf{0 . 0 4 0} \\
(0.015)\end{array}$ & $\begin{array}{c}0.013 \\
(0.009)\end{array}$ & $\begin{array}{c}\mathbf{0 . 0 8 2} \\
(0.026)\end{array}$ & $\begin{array}{c}\mathbf{0 . 0 5 9} \\
(0.025)\end{array}$ \\
\hline $10-14$ & $\begin{array}{c}0.011 \\
(0.008)\end{array}$ & $\begin{array}{c}\mathbf{0 . 0 8 1} \\
(0.024)\end{array}$ & $\begin{array}{c}\mathbf{0 . 0 4 8} \\
(0.022)\end{array}$ & $\begin{array}{c}0.014 \\
(0.014)\end{array}$ & $\begin{array}{c}\mathbf{0 . 1 0 9} \\
(0.038)\end{array}$ & $\begin{array}{c}\mathbf{0 . 0 9 7} \\
(0.041)\end{array}$ & $\begin{array}{c}0.011 \\
(0.008)\end{array}$ & $\begin{array}{c}\mathbf{0 . 0 8 0} \\
(0.024)\end{array}$ & $\begin{array}{c}\mathbf{0 . 0 4 6} \\
(0.022)\end{array}$ & $\begin{array}{c}0.008 \\
(0.015)\end{array}$ & $\begin{array}{c}\mathbf{0 . 0 9 6} \\
(0.041)\end{array}$ & $\begin{array}{c}\mathbf{0 . 0 8 7} \\
(0.041)\end{array}$ \\
\hline $15^{+}$ & $\begin{array}{c}0.010 \\
(0.009)\end{array}$ & $\begin{array}{c}\mathbf{0 . 0 7 2} \\
(0.028)\end{array}$ & $\begin{array}{c}\mathbf{0 . 0 5 0} \\
(0.026)\end{array}$ & $\begin{array}{c}0.019 \\
(0.017)\end{array}$ & $\begin{array}{c}\mathbf{0 . 1 2 6} \\
(0.046)\end{array}$ & $\begin{array}{c}\mathbf{0 . 1 2 8} \\
(0.050)\end{array}$ & & & & & & \\
\hline Sample Size & 241,919 & 241,919 & 241,919 & 19,370 & 19,370 & 19,370 & 234,298 & 234,298 & 234,298 & 16,500 & 16,500 & 16,500 \\
\hline
\end{tabular}

All models also include age, age squared, years of education, and indicators for married, employed, urban, region and survey year. NHIS annual weights used. Marginal effects reported for all probit models. Standard errors in parentheses. Specification 1 top-codes the $15+$ ysm group at 29 years since arrival while Specification 2 omits the $15+$ ysm group. Bold results are statisticaly significant at the $10 \%$ level. 
Appendix Table 6b. Immigrant Cohort and Assimilation Effects of BMI Excluding Immigrants who Arrived Before Age 15 for Men by Race/Ethnic Origin

\begin{tabular}{|c|c|c|c|c|c|c|c|c|c|c|c|c|}
\hline & \multicolumn{6}{|c|}{ Specification 1} & \multicolumn{6}{|c|}{ Specification 2} \\
\hline & Ln BMI & $\begin{array}{l}\text { All Origins } \\
\text { Overweight }\end{array}$ & Obese & Ln BMI & $\begin{array}{c}\text { Hispanic } \\
\text { Overweight }\end{array}$ & Obese & Ln BMI & $\begin{array}{l}\text { All Origins } \\
\text { Overweight }\end{array}$ & Obese & Ln BMI & $\begin{array}{c}\text { Hispanic } \\
\text { Overweight }\end{array}$ & Obese \\
\hline \multicolumn{13}{|l|}{$\underline{\text { Cohort Effects }}$} \\
\hline \multicolumn{13}{|l|}{$\overline{\text { Immigrated: }}$} \\
\hline 1980 or Before & $\begin{array}{c}\mathbf{- 0 . 0 3 6} \\
(0.007)\end{array}$ & $\begin{array}{c}\mathbf{- 0 . 1 3 4} \\
(0.027)\end{array}$ & $\begin{array}{c}\mathbf{- 0 . 0 8 2} \\
(0.016)\end{array}$ & $\begin{array}{l}\mathbf{- 0 . 0 3 8} \\
(0.014)\end{array}$ & $\begin{array}{c}\mathbf{- 0 . 1 4 8} \\
(0.049)\end{array}$ & $\begin{array}{l}\mathbf{- 0 . 1 0 7} \\
(0.028)\end{array}$ & $\begin{array}{l}\mathbf{- 0 . 0 3 6} \\
(0.007)\end{array}$ & $\begin{array}{c}\mathbf{- 0 . 1 3 2} \\
(0.027)\end{array}$ & $\begin{array}{c}\mathbf{- 0 . 0 8 1} \\
(0.015)\end{array}$ & $\begin{array}{c}\mathbf{- 0 . 0 4 2} \\
(0.015)\end{array}$ & $\begin{array}{c}\mathbf{- 0 . 1 6 6} \\
(0.051)\end{array}$ & $\begin{array}{c}\mathbf{- 0 . 1 0 8} \\
(0.023)\end{array}$ \\
\hline 1981-85 & $\begin{array}{l}-\mathbf{0 . 0 4 9} \\
(0.005)\end{array}$ & $\begin{array}{l}-0.153 \\
(0.020)\end{array}$ & $\begin{array}{c}\mathbf{- 0 . 0 9 8} \\
(0.010)\end{array}$ & $\begin{array}{c}\mathbf{- 0 . 0 5 0} \\
(0.010)\end{array}$ & $\begin{array}{c}-\mathbf{0 . 1 6 2} \\
(0.034)\end{array}$ & $\begin{array}{l}\mathbf{- 0 . 1 1 7} \\
(0.017)\end{array}$ & $\begin{array}{c}\mathbf{- 0 . 0 4 9} \\
(0.005)\end{array}$ & $\begin{array}{c}-\mathbf{0 . 1 5 1} \\
(0.020)\end{array}$ & $\begin{array}{c}\mathbf{- 0 . 0 9 8} \\
(0.010)\end{array}$ & $\begin{array}{c}-\mathbf{0 . 0 5 2} \\
(0.010)\end{array}$ & $\begin{array}{c}-\mathbf{0 . 1 7 1} \\
(0.035)\end{array}$ & $\begin{array}{l}\mathbf{- 0 . 1 2 3} \\
(0.017)\end{array}$ \\
\hline 1986-90 & $\begin{array}{c}-\mathbf{0 . 0 5 4} \\
(0.003)\end{array}$ & $\begin{array}{c}-\mathbf{- 0 . 1 6 8} \\
(0.011)\end{array}$ & $\begin{array}{l}-\mathbf{- 0 . 1 0 5} \\
(0.005)\end{array}$ & $\begin{array}{c}-\mathbf{0 . 0 6 2} \\
(0.006)\end{array}$ & $\begin{array}{l}-\mathbf{0 . 1 9 7} \\
(0.019)\end{array}$ & $\begin{array}{c}-\mathbf{- 0 . 1 3 0} \\
(0.010)\end{array}$ & $\begin{array}{l}\mathbf{- 0 . 0 5 4} \\
(0.003)\end{array}$ & $\begin{array}{c}-\mathbf{- 0 . 1 6 8} \\
(0.011)\end{array}$ & $\begin{array}{l}-\mathbf{- 0 . 1 0 5} \\
(0.005)\end{array}$ & $\begin{array}{l}-\mathbf{0 . 0 6 3} \\
(0.006)\end{array}$ & $\begin{array}{l}-\mathbf{- 0 . 1 9 9} \\
(0.019)\end{array}$ & $\begin{array}{l}\mathbf{- 0 . 1 3 3} \\
(0.010)\end{array}$ \\
\hline 1991-95 & $\begin{array}{l}\mathbf{- 0 . 0 6 5} \\
(0.003)\end{array}$ & $\begin{array}{c}-\mathbf{0 . 1 7 1} \\
(0.012)\end{array}$ & $\begin{array}{l}\mathbf{- 0 . 1 0 4} \\
(0.006)\end{array}$ & $\begin{array}{c}\mathbf{- 0 . 0 8 1} \\
(0.006)\end{array}$ & $\begin{array}{c}-\mathbf{0 . 2 0 4} \\
(0.020)\end{array}$ & $\begin{array}{c}-\mathbf{0 . 1 3 4} \\
(0.008)\end{array}$ & $\begin{array}{l}-\mathbf{0 . 0 6 5} \\
(0.003)\end{array}$ & $\begin{array}{c}-\mathbf{0 . 1 7 1} \\
(0.012)\end{array}$ & $\begin{array}{l}-\mathbf{0 . 1 0 4} \\
(0.006)\end{array}$ & $\begin{array}{l}-\mathbf{0 . 0 8 0} \\
(0.006)\end{array}$ & $\begin{array}{l}-\mathbf{- 0 . 1 9 8} \\
(0.020)\end{array}$ & $\begin{array}{l}\mathbf{- 0 . 1 3 3} \\
(0.008)\end{array}$ \\
\hline \multicolumn{13}{|c|}{ Assimilation Effects } \\
\hline $5-9$ & $\begin{array}{l}-0.006 \\
(0.004)\end{array}$ & $\begin{array}{c}0.016 \\
(0.016)\end{array}$ & $\begin{array}{l}-0.012 \\
(0.014)\end{array}$ & $\begin{array}{l}\mathbf{- 0 . 0 1 5} \\
(0.007)\end{array}$ & $\begin{array}{c}0.006 \\
(0.025)\end{array}$ & $\begin{array}{l}-0.023 \\
(0.021)\end{array}$ & $\begin{array}{l}-0.007 \\
(0.004)\end{array}$ & $\begin{array}{c}0.015 \\
(0.016)\end{array}$ & $\begin{array}{l}-0.012 \\
(0.014)\end{array}$ & $\begin{array}{c}\mathbf{- 0 . 0 1 4} \\
(0.008)\end{array}$ & $\begin{array}{c}0.012 \\
(0.026)\end{array}$ & $\begin{array}{l}-0.018 \\
(0.022)\end{array}$ \\
\hline $10-14$ & $\begin{array}{l}-0.004 \\
(0.006)\end{array}$ & $\begin{array}{c}0.030 \\
(0.023)\end{array}$ & $\begin{array}{l}-0.006 \\
(0.021)\end{array}$ & $\begin{array}{l}-0.012 \\
(0.012)\end{array}$ & $\begin{array}{c}0.035 \\
(0.039)\end{array}$ & $\begin{array}{l}-0.017 \\
(0.033)\end{array}$ & $\begin{array}{l}-0.005 \\
(0.006)\end{array}$ & $\begin{array}{c}0.029 \\
(0.023)\end{array}$ & $\begin{array}{l}-0.006 \\
(0.022)\end{array}$ & $\begin{array}{l}-0.010 \\
(0.013)\end{array}$ & $\begin{array}{c}0.048 \\
(0.040)\end{array}$ & $\begin{array}{l}-0.006 \\
(0.035)\end{array}$ \\
\hline $15^{+}$ & $\begin{array}{c}0.003 \\
(0.007)\end{array}$ & $\begin{array}{c}\mathbf{0 . 0 4 6} \\
(0.027)\end{array}$ & $\begin{array}{c}0.025 \\
(0.027)\end{array}$ & $\begin{array}{l}-0.002 \\
(0.015)\end{array}$ & $\begin{array}{c}0.051 \\
(0.047)\end{array}$ & $\begin{array}{c}0.028 \\
(0.044)\end{array}$ & & & & & & \\
\hline Sample Size & 219,945 & 219,945 & 219,945 & 17,531 & 17,531 & 17,531 & 213,837 & 213,837 & 213,837 & 15,058 & 15,058 & 15,058 \\
\hline
\end{tabular}

All models also include age, age squared, years of education, and indicators for married, employed, urban, region and survey year. NHIS annual weights used. Marginal effects reported for all probit models. Standard errors in parentheses. Specification 1 top-codes the $15+$ ysm group at 29 years since arrival while Specification 2 omits the $15+$ ysm group. Bold results are statisticaly significant at the $10 \%$ level. 
Appendix Table 7. Immigrant Cohort and Assimilation Effects of BMI for Women Age 35+ by Race/Ethnic Origin

\begin{tabular}{|c|c|c|c|c|c|c|c|c|c|c|c|c|}
\hline & \multicolumn{3}{|c|}{ All Origins } & \multicolumn{3}{|c|}{ Hispanic } & \multicolumn{3}{|c|}{ White } & \multicolumn{3}{|c|}{ Black } \\
\hline & Ln BMI & Overweight & Obese & Ln BMI & Overweight & Obese & Ln BMI & Overweight & Obese & Ln BMI & Overweight & Obese \\
\hline \multicolumn{13}{|l|}{ Cohort Effects } \\
\hline \multicolumn{13}{|l|}{$\overline{\text { Immigrated: }}$} \\
\hline \multirow[t]{2}{*}{1980 or Before } & -0.044 & -0.125 & -0.098 & -0.068 & -0.139 & -0.227 & -0.009 & -0.066 & -0.079 & 0.047 & 0.033 & 0.182 \\
\hline & $(0.013)$ & $(0.037)$ & $(0.023)$ & $(0.024)$ & $(0.067)$ & $(0.058)$ & $(0.023)$ & $(0.072)$ & $(0.042)$ & $(0.040)$ & $(0.106)$ & $(0.127)$ \\
\hline \multirow[t]{2}{*}{ 1981-85 } & -0.051 & -0.108 & -0.101 & -0.060 & -0.131 & -0.164 & -0.021 & -0.061 & -0.088 & -0.003 & 0.052 & 0.037 \\
\hline & $(0.010)$ & $(0.030)$ & $(0.016)$ & $(0.018)$ & $(0.057)$ & $(0.035)$ & $(0.019)$ & $(0.056)$ & $(0.030)$ & $(0.032)$ & $(0.081)$ & $(0.101)$ \\
\hline \multirow[t]{2}{*}{$1986-90$} & -0.036 & -0.057 & -0.092 & -0.041 & -0.040 & -0.115 & 0.009 & 0.005 & -0.068 & -0.024 & 0.063 & -0.122 \\
\hline & $(0.006)$ & $(0.018)$ & $(0.010)$ & $(0.011)$ & $(0.033)$ & $(0.024)$ & $(0.011)$ & $(0.033)$ & $(0.019)$ & $(0.018)$ & $(0.051)$ & $(0.051)$ \\
\hline \multirow[t]{2}{*}{ 1991-95 } & -0.039 & -0.062 & -0.083 & -0.047 & -0.036 & -0.122 & 0.021 & 0.069 & -0.022 & -0.038 & 0.025 & 0.043 \\
\hline & $(0.006)$ & $(0.019)$ & $(0.011)$ & $(0.010)$ & $(0.033)$ & $(0.023)$ & $(0.010)$ & $(0.034)$ & $(0.024)$ & $(0.028)$ & $(0.071)$ & $(0.083)$ \\
\hline \multicolumn{13}{|c|}{ Assimilation Effects } \\
\hline \multicolumn{13}{|c|}{ Years Since Arrival: } \\
\hline \multirow[t]{2}{*}{$5-9$} & 0.020 & 0.054 & 0.026 & 0.020 & 0.065 & 0.035 & 0.011 & 0.026 & 0.051 & -0.011 & -0.060 & -0.072 \\
\hline & $(0.008)$ & $(0.025)$ & $(0.022)$ & $(0.014)$ & $(0.039)$ & $(0.041)$ & $(0.016)$ & $(0.047)$ & $(0.045)$ & $(0.026)$ & $(0.081)$ & $(0.075)$ \\
\hline \multirow[t]{2}{*}{$10-14$} & 0.026 & 0.089 & 0.039 & 0.033 & 0.112 & 0.116 & 0.021 & 0.065 & 0.045 & -0.039 & 0.006 & -0.173 \\
\hline & $(0.012)$ & $(0.034)$ & $(0.032)$ & $(0.021)$ & $(0.051)$ & $(0.063)$ & $(0.022)$ & $(0.067)$ & $(0.063)$ & $(0.035)$ & $(0.101)$ & $(0.083)$ \\
\hline \multirow[t]{2}{*}{$15^{+}$} & 0.035 & 0.114 & 0.051 & 0.049 & 0.150 & 0.153 & 0.007 & 0.036 & 0.022 & -0.079 & -0.046 & -0.223 \\
\hline & $(0.013)$ & $(0.038)$ & $(0.036)$ & $(0.024)$ & $(0.063)$ & $(0.066)$ & $(0.023)$ & $(0.074)$ & $(0.065)$ & $(0.040)$ & $(0.121)$ & $(0.080)$ \\
\hline Sample Size & 152,427 & 152,427 & 152,427 & 11,911 & 11,911 & 11,911 & 113,541 & 113,541 & 113,541 & 21,473 & 21,473 & 21,473 \\
\hline
\end{tabular}

All models also include age, age squared, years of education, and indicators for married, employed, urban, region and survey year. NHIS annual weights used. Marginal effects reported for all probit models. Standard errors in parentheses. Bold results are statisticaly significant at the $10 \%$ level. 
Appendix Table 8. BMI Trends By Gender, Age, and Nativity

\begin{tabular}{|c|c|c|c|c|c|c|c|c|}
\hline & \multicolumn{4}{|c|}{ Females } & \multicolumn{4}{|c|}{$\underline{\text { Males }}$} \\
\hline & \multicolumn{2}{|c|}{$\underline{20-29}$} & \multicolumn{2}{|c|}{ - $\quad \underline{30-39}$} & \multicolumn{2}{|c|}{$\underline{20-29}$} & \multicolumn{2}{|c|}{$\underline{30-39}$} \\
\hline & Immigrants & Natives & Immigrants & Natives & Immigrants & Natives & Immigrants & Natives \\
\hline \multicolumn{9}{|l|}{ All Origins } \\
\hline 1989 & $\begin{array}{l}22.787 \\
(3.683)\end{array}$ & $\begin{array}{l}23.452 \\
(4.875)\end{array}$ & $\begin{array}{l}23.681 \\
(3.876)\end{array}$ & $\begin{array}{l}24.641 \\
(5.528)\end{array}$ & $\begin{array}{l}23.405 \\
(4.119)\end{array}$ & $\begin{array}{l}24.930 \\
(4.069)\end{array}$ & $\begin{array}{l}24.483 \\
(3.813)\end{array}$ & $\begin{array}{l}26.080 \\
(4.191)\end{array}$ \\
\hline 1990 & $\begin{array}{l}23.852 \\
(4.894)\end{array}$ & $\begin{array}{l}23.652 \\
(5.053)\end{array}$ & $\begin{array}{l}23.836 \\
(3.725)\end{array}$ & $\begin{array}{l}24.706 \\
(5.485)\end{array}$ & $\begin{array}{l}23.741 \\
(3.426)\end{array}$ & $\begin{array}{l}24.978 \\
(4.056)\end{array}$ & $\begin{array}{l}24.459 \\
(3.341)\end{array}$ & $\begin{array}{l}26.204 \\
(4.315)\end{array}$ \\
\hline 1991 & $\begin{array}{l}23.595 \\
(3.729)\end{array}$ & $\begin{array}{l}23.885 \\
(5.220)\end{array}$ & $\begin{array}{l}24.540 \\
(4.554)\end{array}$ & $\begin{array}{l}25.024 \\
(5.672)\end{array}$ & $\begin{array}{l}23.881 \\
(2.751)\end{array}$ & $\begin{array}{l}25.075 \\
(4.304)\end{array}$ & $\begin{array}{l}24.843 \\
(3.410)\end{array}$ & $\begin{array}{l}26.273 \\
(4.332)\end{array}$ \\
\hline 1992 & $\begin{array}{l}23.476 \\
(4.057)\end{array}$ & $\begin{array}{l}23.965 \\
(5.261)\end{array}$ & $\begin{array}{l}24.220 \\
(4.753)\end{array}$ & $\begin{array}{l}25.143 \\
(5.759)\end{array}$ & $\begin{array}{l}23.914 \\
(3.905)\end{array}$ & $\begin{array}{l}25.184 \\
(4.276)\end{array}$ & $\begin{array}{l}24.823 \\
(3.993)\end{array}$ & $\begin{array}{l}26.488 \\
(4.567)\end{array}$ \\
\hline 1993 & $\begin{array}{l}23.243 \\
(4.077)\end{array}$ & $\begin{array}{l}24.244 \\
(5.489)\end{array}$ & $\begin{array}{l}24.394 \\
(4.166)\end{array}$ & $\begin{array}{l}25.181 \\
(5.817)\end{array}$ & $\begin{array}{l}23.632 \\
(2.977)\end{array}$ & $\begin{array}{l}25.389 \\
(4.387)\end{array}$ & $\begin{array}{l}24.562 \\
(3.832)\end{array}$ & $\begin{array}{l}26.521 \\
(4.461)\end{array}$ \\
\hline 1994 & $\begin{array}{l}23.402 \\
(4.206)\end{array}$ & $\begin{array}{l}24.254 \\
(5.565)\end{array}$ & $\begin{array}{l}23.973 \\
(4.310)\end{array}$ & $\begin{array}{l}25.231 \\
(5.918)\end{array}$ & $\begin{array}{l}23.580 \\
(3.473)\end{array}$ & $\begin{array}{l}25.452 \\
(4.486)\end{array}$ & $\begin{array}{l}25.179 \\
(3.340)\end{array}$ & $\begin{array}{l}26.577 \\
(4.432)\end{array}$ \\
\hline 1995 & $\begin{array}{l}23.615 \\
(4.743)\end{array}$ & $\begin{array}{l}24.421 \\
(5.670)\end{array}$ & $\begin{array}{l}24.234 \\
(4.611)\end{array}$ & $\begin{array}{l}25.521 \\
(6.098)\end{array}$ & $\begin{array}{l}24.127 \\
(3.684)\end{array}$ & $\begin{array}{l}25.688 \\
(4.697)\end{array}$ & $\begin{array}{l}24.439 \\
(2.886)\end{array}$ & $\begin{array}{l}26.847 \\
(4.597)\end{array}$ \\
\hline 1996 & $\begin{array}{l}23.611 \\
(4.228)\end{array}$ & $\begin{array}{l}24.700 \\
(5.612)\end{array}$ & $\begin{array}{l}24.596 \\
(4.590)\end{array}$ & $\begin{array}{l}25.446 \\
(5.975)\end{array}$ & $\begin{array}{l}23.926 \\
(3.140)\end{array}$ & $\begin{array}{l}25.824 \\
(4.475)\end{array}$ & $\begin{array}{l}25.050 \\
(3.277)\end{array}$ & $\begin{array}{l}26.922 \\
(4.438)\end{array}$ \\
\hline \multicolumn{9}{|l|}{ Hispanic } \\
\hline 1989 & $\begin{array}{l}24.192 \\
(4.021)\end{array}$ & $\begin{array}{l}24.752 \\
(5.540)\end{array}$ & $\begin{array}{l}25.792 \\
(4.525)\end{array}$ & $\begin{array}{l}26.534 \\
(6.449)\end{array}$ & $\begin{array}{l}24.626 \\
(5.335)\end{array}$ & $\begin{array}{l}25.999 \\
(4.501)\end{array}$ & $\begin{array}{l}25.446 \\
(4.981)\end{array}$ & $\begin{array}{l}27.473 \\
(4.731)\end{array}$ \\
\hline 1990 & $\begin{array}{l}24.966 \\
(3.609)\end{array}$ & $\begin{array}{l}24.969 \\
(5.030)\end{array}$ & $\begin{array}{l}25.677 \\
(2.961)\end{array}$ & $\begin{array}{l}26.161 \\
(5.797)\end{array}$ & $\begin{array}{l}24.494 \\
(3.863)\end{array}$ & $\begin{array}{l}25.887 \\
(4.498)\end{array}$ & $\begin{array}{l}24.637 \\
(3.238)\end{array}$ & $\begin{array}{l}27.351 \\
(4.475)\end{array}$ \\
\hline 1991 & $\begin{array}{l}24.865 \\
(3.853)\end{array}$ & $\begin{array}{l}25.080 \\
(5.513)\end{array}$ & $\begin{array}{l}27.322 \\
(4.839)\end{array}$ & $\begin{array}{l}26.913 \\
(6.121)\end{array}$ & $\begin{array}{l}24.108 \\
(2.676)\end{array}$ & $\begin{array}{l}26.137 \\
(4.715)\end{array}$ & $\begin{array}{l}26.050 \\
(3.887)\end{array}$ & $\begin{array}{l}27.195 \\
(4.459)\end{array}$ \\
\hline 1992 & $\begin{array}{l}24.506 \\
(3.799)\end{array}$ & $\begin{array}{l}24.800 \\
(5.431)\end{array}$ & $\begin{array}{l}25.378 \\
(3.907)\end{array}$ & $\begin{array}{l}27.162 \\
(6.110)\end{array}$ & $\begin{array}{l}24.610 \\
(4.651)\end{array}$ & $\begin{array}{l}25.945 \\
(4.657)\end{array}$ & $\begin{array}{l}26.433 \\
(5.973)\end{array}$ & $\begin{array}{l}27.823 \\
(4.767)\end{array}$ \\
\hline 1993 & $\begin{array}{l}24.818 \\
(3.919)\end{array}$ & $\begin{array}{l}25.740 \\
(5.552)\end{array}$ & $\begin{array}{l}26.089 \\
(3.600)\end{array}$ & $\begin{array}{l}27.565 \\
(7.085)\end{array}$ & $\begin{array}{l}24.020 \\
(2.835)\end{array}$ & $\begin{array}{l}26.328 \\
(4.589)\end{array}$ & $\begin{array}{l}25.972 \\
(3.613)\end{array}$ & $\begin{array}{l}27.353 \\
(5.160)\end{array}$ \\
\hline 1994 & $\begin{array}{l}24.946 \\
(4.536)\end{array}$ & $\begin{array}{l}25.470 \\
(6.181)\end{array}$ & $\begin{array}{l}26.426 \\
(4.747)\end{array}$ & $\begin{array}{l}27.195 \\
(6.565)\end{array}$ & $\begin{array}{l}23.941 \\
(3.937)\end{array}$ & $\begin{array}{l}26.201 \\
(4.667)\end{array}$ & $\begin{array}{l}27.108 \\
(3.253)\end{array}$ & $\begin{array}{l}27.714 \\
(4.277)\end{array}$ \\
\hline 1995 & $\begin{array}{l}25.700 \\
(4.381)\end{array}$ & $\begin{array}{l}25.689 \\
(6.235)\end{array}$ & $\begin{array}{l}26.535 \\
(4.840)\end{array}$ & $\begin{array}{l}26.901 \\
(6.118)\end{array}$ & $\begin{array}{l}24.184 \\
(3.186)\end{array}$ & $\begin{array}{l}26.777 \\
(5.084)\end{array}$ & $\begin{array}{l}25.256 \\
(3.170)\end{array}$ & $\begin{array}{l}27.866 \\
(5.057)\end{array}$ \\
\hline 1996 & $\begin{array}{l}25.151 \\
(4.548)\end{array}$ & $\begin{array}{l}26.104 \\
(6.219)\end{array}$ & $\begin{array}{l}26.759 \\
(4.956)\end{array}$ & $\begin{array}{l}27.406 \\
(6.588)\end{array}$ & $\begin{array}{l}24.368 \\
(3.003)\end{array}$ & $\begin{array}{l}26.879 \\
(5.192)\end{array}$ & $\begin{array}{l}25.613 \\
(3.322)\end{array}$ & $\begin{array}{l}27.905 \\
(4.965)\end{array}$ \\
\hline
\end{tabular}


Appendix Table 8 (Continued). BMI Trends By Gender, Age, and Nativity

\begin{tabular}{|c|c|c|c|c|c|c|c|c|}
\hline & \multicolumn{4}{|c|}{ Females } & \multicolumn{4}{|c|}{$\underline{\text { Males }}$} \\
\hline & \multicolumn{2}{|c|}{$\underline{20-29}$} & \multicolumn{2}{|c|}{$\underline{30-39}$} & \multicolumn{2}{|c|}{$\underline{20-29}$} & \multicolumn{2}{|c|}{$\underline{30-39}$} \\
\hline & Immigrants & Natives & Immigrants & Natives & Immigrants & Natives & Immigrants & Natives \\
\hline \multicolumn{9}{|l|}{ White } \\
\hline 1989 & $\begin{array}{r}23.109 \\
(3.129)\end{array}$ & $\begin{array}{c}23.012 \\
(4.538)\end{array}$ & $\begin{array}{c}24.267 \\
(3.810)\end{array}$ & $\begin{array}{r}24.165 \\
(5.168)\end{array}$ & $\begin{array}{l}23.734 \\
(2.352)\end{array}$ & $\begin{array}{r}24.871 \\
(3.972)\end{array}$ & $\begin{array}{c}24.619 \\
(2.206)\end{array}$ & $\begin{array}{r}26.039 \\
(4.085)\end{array}$ \\
\hline 1990 & $\begin{array}{r}23.673 \\
(3.223)\end{array}$ & $\begin{array}{r}23.220 \\
(4.793)\end{array}$ & $\begin{array}{r}23.940 \\
(3.536)\end{array}$ & $\begin{array}{l}24.217 \\
(5.205)\end{array}$ & $\begin{array}{l}23.580 \\
(2.668)\end{array}$ & $\begin{array}{r}24.928 \\
(3.917)\end{array}$ & $\begin{array}{l}24.687 \\
(2.836)\end{array}$ & $\begin{array}{c}26.131 \\
(4.216)\end{array}$ \\
\hline 1991 & $\begin{array}{r}23.428 \\
(3.016)\end{array}$ & $\begin{array}{r}23.338 \\
(4.809)\end{array}$ & $\begin{array}{r}23.336 \\
(3.212)\end{array}$ & $\begin{array}{c}24.472 \\
(5.341)\end{array}$ & $\begin{array}{l}24.095 \\
(2.727)\end{array}$ & $\begin{array}{l}24.951 \\
(4.132)\end{array}$ & $\begin{array}{r}24.706 \\
(3.088)\end{array}$ & $\begin{array}{c}26.231 \\
(4.256)\end{array}$ \\
\hline 1992 & $\begin{array}{r}23.542 \\
(3.821)\end{array}$ & $\begin{array}{r}23.495 \\
(4.910)\end{array}$ & $\begin{array}{r}25.584 \\
(6.762)\end{array}$ & $\begin{array}{r}24.634 \\
(5.474)\end{array}$ & $\begin{array}{l}24.251 \\
(3.127)\end{array}$ & $\begin{array}{c}25.109 \\
(4.143)\end{array}$ & $\begin{array}{l}24.841 \\
(3.113)\end{array}$ & $\begin{array}{r}26.469 \\
(4.501)\end{array}$ \\
\hline 1993 & $\begin{array}{l}23.901 \\
(4.690)\end{array}$ & $\begin{array}{l}23.605 \\
(4.976)\end{array}$ & $\begin{array}{r}24.390 \\
(3.632)\end{array}$ & $\begin{array}{c}24.601 \\
(5.489)\end{array}$ & $\begin{array}{l}24.484 \\
(3.405)\end{array}$ & $\begin{array}{l}25.236 \\
(4.209)\end{array}$ & $\begin{array}{c}25.724 \\
(3.621)\end{array}$ & $\begin{array}{c}26.431 \\
(4.269)\end{array}$ \\
\hline 1994 & $\begin{array}{l}24.153 \\
(4.495)\end{array}$ & $\begin{array}{c}23.661 \\
(5.148)\end{array}$ & $\begin{array}{r}23.499 \\
(3.563)\end{array}$ & $\begin{array}{r}24.694 \\
(5.553)\end{array}$ & $\begin{array}{l}24.032 \\
(3.062)\end{array}$ & $\begin{array}{r}25.294 \\
(4.312)\end{array}$ & $\begin{array}{c}25.063 \\
(3.381)\end{array}$ & $\begin{array}{r}26.483 \\
(4.314)\end{array}$ \\
\hline 1995 & $\begin{array}{l}24.004 \\
(4.606)\end{array}$ & $\begin{array}{r}23.849 \\
(5.249)\end{array}$ & $\begin{array}{r}23.962 \\
(3.503)\end{array}$ & $\begin{array}{c}24.962 \\
(5.737)\end{array}$ & $\begin{array}{c}25.165 \\
(4.707)\end{array}$ & $\begin{array}{c}25.484 \\
(4.526)\end{array}$ & $\begin{array}{r}24.836 \\
(2.740)\end{array}$ & $\begin{array}{l}26.785 \\
(4.450)\end{array}$ \\
\hline 1996 & $\begin{array}{l}22.886 \\
(2.580)\end{array}$ & $\begin{array}{l}24.074 \\
(5.149)\end{array}$ & $\begin{array}{l}23.728 \\
(4.304)\end{array}$ & $\begin{array}{r}24.836 \\
(5.645)\end{array}$ & $\begin{array}{l}23.927 \\
(3.029)\end{array}$ & $\begin{array}{r}25.670 \\
(4.256)\end{array}$ & $\begin{array}{l}25.126 \\
(2.835)\end{array}$ & $\begin{array}{l}26.826 \\
(4.329)\end{array}$ \\
\hline \multicolumn{9}{|l|}{ Black } \\
\hline 1989 & $\begin{array}{c}23.605 \\
(3.561)\end{array}$ & $\begin{array}{r}25.358 \\
(5.596)\end{array}$ & $\begin{array}{r}23.630 \\
(2.503)\end{array}$ & $\begin{array}{c}27.039 \\
(6.566)\end{array}$ & $\begin{array}{r}23.749 \\
(3.050)\end{array}$ & $\begin{array}{c}24.861 \\
(4.299)\end{array}$ & $\begin{array}{c}24.941 \\
(3.815)\end{array}$ & $\begin{array}{r}26.050 \\
(4.708)\end{array}$ \\
\hline 1990 & $\begin{array}{r}23.875 \\
(3.522)\end{array}$ & $\begin{array}{r}25.569 \\
(5.896)\end{array}$ & $\begin{array}{c}26.215 \\
(3.875)\end{array}$ & $\begin{array}{c}27.234 \\
(6.253)\end{array}$ & $\begin{array}{c}23.563 \\
(2.867)\end{array}$ & $\begin{array}{r}25.103 \\
(4.687)\end{array}$ & $\begin{array}{r}25.373 \\
(2.932)\end{array}$ & $\begin{array}{r}26.388 \\
(4.840)\end{array}$ \\
\hline 1991 & $\begin{array}{r}24.978 \\
(3.832)\end{array}$ & $\begin{array}{r}26.128 \\
(6.302)\end{array}$ & $\begin{array}{r}26.129 \\
(4.912)\end{array}$ & $\begin{array}{r}27.603 \\
(6.484)\end{array}$ & $\begin{array}{l}24.716 \\
(3.105)\end{array}$ & $\begin{array}{c}25.144 \\
(4.836)\end{array}$ & $\begin{array}{l}25.501 \\
(3.137)\end{array}$ & $\begin{array}{c}26.291 \\
(4.783)\end{array}$ \\
\hline 1992 & $\begin{array}{l}26.057 \\
(4.319)\end{array}$ & $\begin{array}{c}26.124 \\
(6.342)\end{array}$ & $\begin{array}{r}26.245 \\
(4.870)\end{array}$ & $\begin{array}{r}27.855 \\
(6.568)\end{array}$ & $\begin{array}{r}24.043 \\
(4.539)\end{array}$ & $\begin{array}{c}25.534 \\
(4.868)\end{array}$ & $\begin{array}{r}26.384 \\
(3.536)\end{array}$ & $\begin{array}{r}26.520 \\
(5.043)\end{array}$ \\
\hline 1993 & $\begin{array}{l}24.037 \\
(3.751)\end{array}$ & $\begin{array}{r}26.810 \\
(6.827)\end{array}$ & $\begin{array}{r}25.542 \\
(5.671)\end{array}$ & $\begin{array}{r}27.845 \\
(6.273)\end{array}$ & $\begin{array}{l}23.545 \\
(2.735)\end{array}$ & $\begin{array}{r}25.889 \\
(5.007)\end{array}$ & $\begin{array}{r}25.857 \\
(2.499)\end{array}$ & $\begin{array}{r}27.043 \\
(5.420)\end{array}$ \\
\hline 1994 & $\begin{array}{r}24.545 \\
(3.800)\end{array}$ & $\begin{array}{l}26.661 \\
(6.479)\end{array}$ & $\begin{array}{r}28.136 \\
(4.805)\end{array}$ & $\begin{array}{r}27.746 \\
(6.936)\end{array}$ & $\begin{array}{r}25.725 \\
(4.017)\end{array}$ & $\begin{array}{r}26.040 \\
(5.217)\end{array}$ & $\begin{array}{r}24.674 \\
(3.410)\end{array}$ & $\begin{array}{r}26.886 \\
(5.129)\end{array}$ \\
\hline 1995 & $\begin{array}{l}25.343 \\
(6.192)\end{array}$ & $\begin{array}{c}26.511 \\
(6.404)\end{array}$ & $\begin{array}{l}27.388 \\
(4.136)\end{array}$ & $\begin{array}{l}28.159 \\
(7.042)\end{array}$ & $\begin{array}{l}25.245 \\
(4.378)\end{array}$ & $\begin{array}{r}26.383 \\
(5.212)\end{array}$ & $\begin{array}{r}24.420 \\
(2.102)\end{array}$ & $\begin{array}{r}26.910 \\
(5.380)\end{array}$ \\
\hline 1996 & $\begin{array}{r}26.021 \\
(9.455)\end{array}$ & $\begin{array}{l}27.224 \\
(6.536)\end{array}$ & $\begin{array}{r}27.941 \\
(5.717)\end{array}$ & $\begin{array}{r}28.329 \\
(6.558)\end{array}$ & $\begin{array}{c}22.622 \\
(2.431)\end{array}$ & $\begin{array}{r}26.199 \\
(5.066)\end{array}$ & $\begin{array}{l}25.168 \\
(4.824)\end{array}$ & $\begin{array}{l}27.248 \\
(4.844)\end{array}$ \\
\hline
\end{tabular}

All statistics use NHIS annual weights. Standard deviations in parentheses. 